\title{
شعر الحلاج* بين الرؤية الصوفية والخطاب الشعري
}

أ.د// أنس الفقيث

anasatia@hotmail.com

ملخص:

جـاءت هذه الدِراسـة لتمثِّل محاولـةً لاستكناه أغوار الرؤيـة الصـوفيَّة مـن خـلال الخطـاب الثِّـعري فـي شـعر الحسـين بـن منصـور الحـلاج، الثــاعر الصوفي الكبير، الذي يمثِّل جيلَ الرُّواد من الصوفيّة، صوفية القرنين الثالث والرابع الهجرين، والذي قُتِل ضحيّة مبادئه، ودار حولَه جدلّ كبيرُ في الثَّرق والغرب.

وطبيعة شعر الحلاج كانت سببًا مباشرًا في اختيار عنوان هذا البحث، فشعر الحلاج لا يخرج في مجمله عن ثلاثة مناحٍ:

المنحى الأول: طرح الرؤية النَّرية من خلال تجربة شعورية مصاحبة. المنحسى الثاني: طـرح الرؤيـة النظريـة بطريقـة مباشـرة تختفـي فيها روح الثاعر أو تكاد.

المنحى الثالث: وصف الحالة الثعورية التي يعيشها دون تعمُّد طرح رؤيسة معينة. وهذا المنحى الأخير يتضمن شعر الحب والعشق الإلهي وما يصاحب ذلك من أحوال.

* أستاذ ورئسيس قسم اللفـة العربيـة، عميد المتطلبـات الجامعيـة، جامعة مصر للعلوم والتكنولوجيا.

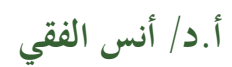

(شعر الحلاج بين الؤية الصوفية والحطاب الشعري.) 
وعلى هذا تم تقسيم البحث إلىى ثلاثـة أقسـام: القسـم الأول وهو الرؤيَّة النظريَّة في شعر الحلاج، وهو القسم الأكبر من شعره؛ حيث يتناول المنحيين

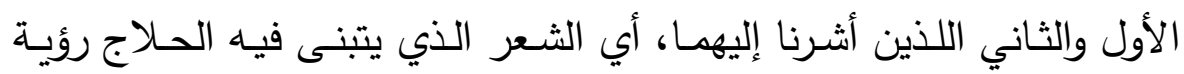
نظرية أو دعوة فكرية يريد أن يوصلها للناس، وهذا الفكر أو هذه الرؤيـة ليست سوى الرؤية الصوفيَّة للحياة والكون والتي سنعرض لقضاياها البارزة في شعر الحلاج، وأهم هذه القضـايا: موقفه من الثـريعة، ونظرته إلى الإنسـان روحًا وجسدًا، ووحدة الأديان، وسطوة الأقدار ووجوب التَّسليم، وحيْرة العقل، وقضية المعرفة والعلم، والصـبة في طريق التَّصوف. ثم نعرض في هذا القسم إلى جانبين متََّلين بهذه الرؤية وهما: شطحات الحلاج، ومنظوماته الملغزة. والقسـم الثاني من البحث يتناول المنحى الثالث، وهو الثِِّعر الصـوفي الوجداني الذي صـاغه تعبيرًا عن حالتهـ الصـوفيّة من عشق وشوق وتوحُّد وتواصل، أو عن شكوى وألم وحزن. أي إنـه الثّّعر الذي يعبّر عن تجربته الصُّوفية الخالصـة دون أن يعمد فيه إلى طرح رؤيسة أو توضيح فكرة أو نشر دعوة نظرية معينة. أمـا القسم الثالث فهو يتتاول الخصائص الأسلوبية لشعر الحلاج عامـة من حيث الموسيقى، والمعجم الثعري، والتراكيب، والصورة الفنية، بما يساعد في تكوين صورة متكاملة عن هذا النتاج الشعري الصوفي الرائد الذي وصلنا عن الحلاج.

بقي أن نشير إلى أن شعر الحسلاج قد ورد غالبًا في سياق أخبار نثريـة تمثِّل مدخلًا أو إطارًا فكريَّا يمكن أن يفيد في توجيه النَّص، ولذلك رأينا أنه من

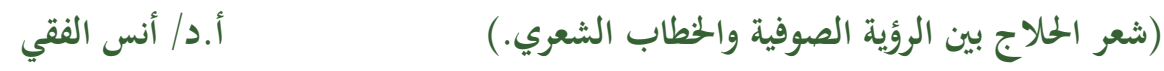


المناسـب الاسـتعانة بـبعض هـذه الأخبـار عنــ تتاولنـا للمقطعـات الثـعرية المتصلة بها.

\section{أما عن نتائج البحث فتتلخص في النقاط التالية:}

- - شعر الحلاج في التَّصوف يمثِّل بكارة التجربـة الشعرية الصوفية في التراث العربي، فهو لم يصل -في مجمله- إلى مرحلـة النُّــ الفني، هذا بالإضافة إلى أن بعض مقطعاته جاءت ضمن مواقف ارتجالية على نحو ما ورد بأخباره، ولذلك لا نجد فيـه مزيـدًا مـن التوظيف الفني للرمـز الصـوفي، مثلما فعل ابن الفارض وابن عربي وغيرهما من كبار شعراء الصوفية الذين جـاءوا بعـده. ولعـل عدم التوفيق في توظيف الرمـز الصـوفي كـان السـبب الرئيسي وراء تلك الشطحات المباشرة التي صدمت رجال الثربعة. - - يغلب على شعر الحـلاج الجانب النَّظري الفكري، وقد أثَّر ذلك في أسلوب الخطاب الثـعري؛ فبدا الثـاعر في كثير من مقطعاته وكأنـه شـارحُ نظرية أو موضح فكرة.

- - تُعدُّ الرؤية النظرية عند الحلاج المنطلق الأساسي لشعره بصفة عامة، وتتمثل في نظرته العليا للإنسان الذي يحمل بداخله سرّ العبودية والألوهية، فهو -في نظر الثاعر - يملك إرادة لا حدود لها يمكن أن توصله إلى الحقيقة المطلقة، كما تتمثل في نظرته غير التقليديـة إلى الثربعة؛ حيث جمـع بين احترامه لها وتوشُّعه في فهم حقائقها، وقد عبَّر في شعره عن هذا التوسُع بما 
لا تطيقه أفهام عامة الناس وبعض رجال الشريعة، فكانت الشطحات، وكان

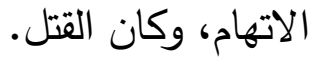

- على الرغم من طغيان الجانب النَّظري في شعره عامة إلا أن للحلاج بعض القصـائد والمقطعات التي عبر فيها عن تجربته الصـوفية الخالصـة، وبخاصة تلك التي تتعلق بالعشق الإلهي وما يصاحبه من معانٍ وجدانية. - - نال الجانب الموسيقي حظًّا وافرًا في شعر الحلاج، فقد جاءت جلُّ قوافيـه مـن النـوع المتواتر المـردف، الذي يناسـب الغنـاء والإنشـاد، وبالتـالي يساعد على انتشار شعره بين الناس. - - ظـاهرة التكرار في شـعر الحـلاج مـن الظـواهر اللافتـة، وقد وضّحح البحث أن التجربة الصوفية بشقيها: النَّظري والوجداني كانت سببًا مباشرًا في

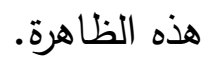
- - إيثار الحلاج للمقطعات الصغيرة والثنائيات في شعره يدفع إلى القول بتأثره بنمط من الثعر الفارسي، وهو ما يُسمى "بالدوبيت" أو المثنوي، وإن لم ينظم على وزنـه، بل إنـه نظّمّ هذه الثنائيات على الأوزان العربية المعهودة، ومع هذا، فإن ذلك يُعدُّ بداية تأثر ظاهري بالثكل العام. ومن الجدير بالذكر أن هـا التأثر قـد تطـور في العصـور اللاحقـة؛ حيـ كتب الثـعراء هـذه الثنائيات باللغة العربية وبالوزن الفارسي. 
- حرص الحلاج في شعره على الاقتراب من أذواق العامة، ومن مظاهر ذلك: استعماله بعض العبارات المتداولة، والمصطلحات اللافتة، وأحيانًا اللغز المصطنع بتوظيف حروف الهجاء.

- للتصـوير الفني عند الحسلاج دور ملحوظ في أداء الرسـالة الشعرية، وعلى الرغم مما أشرنا إليه سابقًا من عدم بلوغ شعره الصوفي عامـة مرحلة النضج الفني، إلا أن أداءه التصويري قد يبلغ أحيانًا مستوى راقيًا بحيث يصل إلى حد الاستشهاد البلاغي بصوره المتقنة التي تجري مجرى المثل أو الحكمة كقوله المشهور : - أك

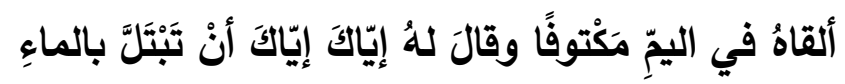
- وأخيرًا فإن قِلّة مـا وصـلنا من شـعر الحـلاج، والتضــارب القائم حول الثِِّعر الذي نسب إليه وإلى غيره في كتب التراجم، يدفع الباحث إلى التوصية بتكثيف البحث وإعـادة النظر في هذا الثـر (المنسوب إليسه وإلى غيره)، ومحاولة التحقق منه، لتكتمل الصورة، وتتحقق الفائدة.

الكلمات المفتاحية: الحلاج - شعر الحلاج - شطحات الحلاج - منظومات الحلاج الملفزة - الثعر الصوفي. 


\section{مقدمة:}

ينطلق هذا البحث من نظريـة مفادها أن النصوص الأدبية بما تحمل من دلالات وتداعيات تقدم للفكر الإنساني تفسيرات وإفادات ونتائج قد لا يستطيع التوصل إليها عن طريق آخر؛ ذلك لأن تلك النصوص إنما تكتب في قالب فنـي متحرر مـن القيـود والأحكـام التي تفرض على غيرهـا مـن النصـوص، بالإضـافة إلى القدرة غير العادية التي يمتلكها النص الأدبي في التوغّل إلى أغوار النفس الإنسانية، والقيام بدور فعّال في عملية التواصل بين الناس. مـن هنـا جـاءت هـذه الدراســة لتمثل محاولـة لاسـتنباط الرؤيسة النظريـة مـن خـلال الخطـاب الثـعري فـي شـعر الحسـين بـن منصــور الحـلاج، الثـاعر الصـوفي الكبيـر، الـذي يمثل جيـل الـرواد مـن الصــوفية، صـوفية القرنين الثالث والرابع الهجرين. والمقصــود بالرؤيسة النظريــة هنــا مجموعـة الأفكـار والمعتقــدات والآراء الكامنــة في شـعر الحـلاج، والتـي اعتبرهـا رســالة فكريـة أراد أن يوصـلها

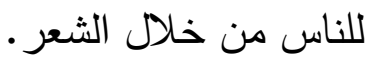
أمــا الخطــاب الثـعري: فهـو ذلــك القالـب الفنـي الــي أودع فيــهـ هـــه الرؤيسة ومـا يصــاحبها مـن مشــاعر وجدانيـة هـي ألصــق مــا تكــون بفـن

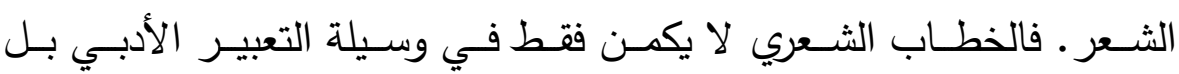

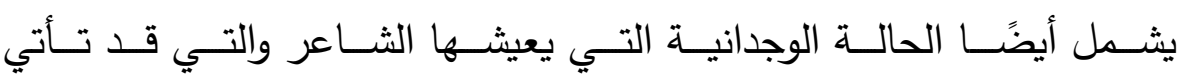
مشفوعة برسالة فكرية يريد الثاعر أن يوصلها إلى المتلقي. 
وطبيعـة شـعر الحــلاج كانــت سـببًا مباشـرًا فـي اختيـار عنـوان هـــا البحـث، فثـعر الحـلاج لا يخـرج فـي مجملـه عـن ثلاثـة منــاح: المنحسى الأول: طــرح الرؤيسـة النظريــة مــن خــلال تجربــة شــورية مصــاحبة. المنحسى الثـاني: طـرح الرؤيـة النظريــة بطريقــة مباشـرة تختفـي فيهـا روح الثـاعر أو تكـاد. المنحسى الثالـث: وصـف الحالـة الثـعورية التـي يعيثـها دون تعدــ طـرح رؤيسة معينـة. وهـذا المنحسى الأخيـر يتضـمن شـعر الحبب والعشـق الإلهي ومـا يصـاحب ذلك مـن أحسوال. ومنهجنـا في هـذا البحـث هـو عـرض هـذه الرؤيسـة النظريـة وتحليلهـا فـي إطارهـا الثـعري، وإبـراز المعـاني الوجدانيـة المصــاحبة، وبعـض السـمات الأسـلوبية التـي تســاعد

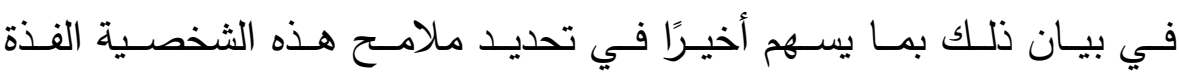

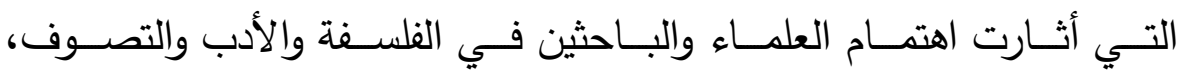

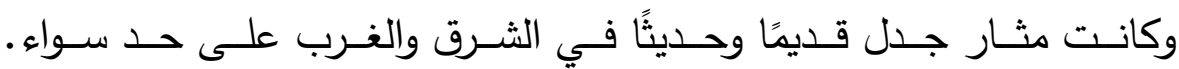
وعلى هــا تـم تقسـيم البحـث إلـى ثلاثــة أقسـام: القسـم الأول وهـو الرؤيسـة النظريـة فـي شـعر الحـلاج، وهـو القسـم الأكبـر مـن شـعره؛ حيـث يتــاول المنحيـين الأول والثـاني اللـذين أشـرنا إليهمــا منــ قليـلـ، أي الثـعر الــي

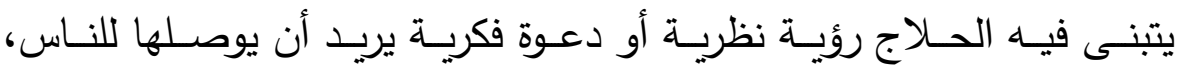
وهذا الأمـر يعرفـه كل مـن قرأ عـن الحـلاج وشـعره وتاريخـه، فالرجل مـتهم

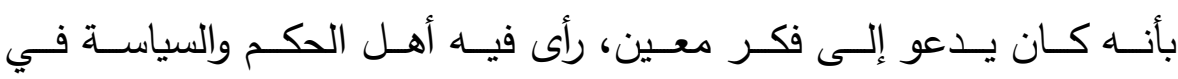
عصـره أنسه مصـدر خطـر عليهم. وهـذا الفكر أو هـذه الرؤيسة ليسـت سـوى الرؤيسـة الصــوفية للحيـاة والكــون والتـي ســنعرض لقضـــاياها البـارزة فـي 


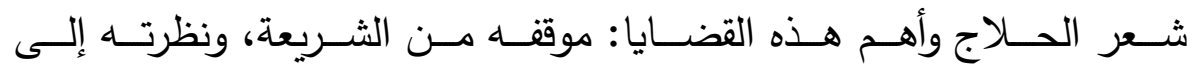
الإنسـان روحًا وجسـدًا، ووحـدة الأديـان، وسـطوة الأقـدار ووجـوب التسـليم، وحيـرة العقـل، وقضـية المعرفـة والعلـم، والصــبة في طريـق التصـوف. ثـم نعـرض في هذا القسـم إلى جـانبيين متصـلين بهذه الرؤيـة وهمـا: شطحات الحلاج، ومنظوماته الملغزة.

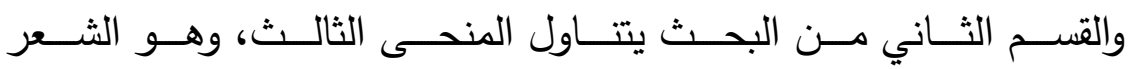
الصــوفي الوجـداني الـذي صــاغه تعبيـرًا عـن حالتـهـ الصـوفية مـن عثـق وشـوق وتوحـــ وتواصـل، أو عـن شـكوى وألــم وحـزن. أي إنـهـ الثـعر الـذي يعبـر عـن تجربتـه الصـوفية الخالصــة دون أن يعمـــ فيـه إلـى طـرح رؤيسة أو توضيح فكرة أو نشر دعوة نظرية معينة. أما القسم الثالث فهو يتناول الخصائص الأسلوبية لشعر الحلاج عامـة من حيث الموسيقى، والمعجم الثعري، والتراكيب، والصورة الفنية، بما يساعد في تكوين صورة متكاملة عن هذا النتاج الثعري الصوفي الرائد الذي وصلنا عن الحلاج.

بقي أن نشير إلى أن شعر الحلاج قد ورد غالًَا في سياق أخبار نثرية تمثل مدخلًا أو إطـارًا فكريَّا يمكن أن يفيد في توجيهـ النص، ولذلك رأينـا أنـه من المناسب الاستعانة ببعض هذه الأخبار عند تتاولنا للمقطعات الثعرية المتصلة بها. 


\section{القسم الأول: الرؤية الصوفية:}

يلاحظ في شعر الحلاج أن جانبًا غير قليل منهـ يغلب عليه النظر والفكر وكأنه يريد أن يفصح عن نظرية معينة للناس عامة وللصوفية خاصة، كما أنه يصرح بنفسه أن نظره في الحياة والكون هو سبب همومه الثقيلة التي اضُّر أن يتحملها في مسيرة حياته. يقول في بداية ديوانه:

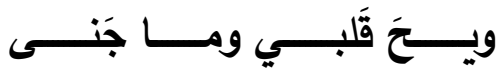

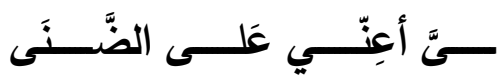

ومسن المعروف أن المـذخل الذوقي هو الأسـاس في فهم الثـعر الصـوفي واصـطلاحاته؛ حيـث إن التصـوف حالـة شعورية تصـل بالإنسـان إلى آفـاق وجدانية عالية تضيق عن وصفها العبارة. والحلاج حاول منذ بداياته الأولى أن يقحم عقله ونظره في تجربته الذوقية، بـل إنـه حاول بعبارته اللغويـة أن يُبلغ للناس رسـالته، فخرجت تعبيراته أحيانًا إشـارات إنسـانية راقية، وأحيانًا أخرى شطحات تصدم رجال الشريعة.

ولا يفوتــا هنـا أن نلحظ أن شـر الحـلاج النظـري لا يخلـو مـن إثـارات وجدانيـة، وفي المقابـل نلحظ أن شعره الوجداني الذوقي لا يخلو من نظرات فكرية متوارية، وهذا التصنيف الموضوعي ليس صارمًا، ولكنه ضروري لتكوين صورة متكاملة عن معاني هذا الثعر الذي تضاربت حوله الآراء. ودراسـة الشـعر الصـوفي تحتـاج إلى خصوصـية في التــاول، فـلا بــ أن يوضــع في الاعتبـار الحالـة التـي يعيثـها الثـاعر، والمرحلـة الصـوفية التـي يجتازها في حياته، وهذا ما يطلق عليه الصـوفية الحال والمقام، فالحال مثل

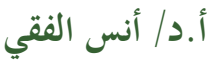

(شعر الحلاج بين الؤية الصوفية والحطاب الشعري.) 
حال الجمع والتوحد وحال السكر والصحو أي الرجوع إلى الحالة الإنسانية التي يعي فيها الشاعر ما يقول ويزنـه بميزان الثرع، وكذلك حال القبض والبسط، أما المرحلة التي يمر بها أو ما يسمى المقام فهو المكانة الثابتة التي يعيشها كمقام الزهد "التوبة والورع" أو المعرفة. الموقف من الثربعة: عبَّر الحسلاج في جانب من شعره عن رؤيسة إسـلامية شرعية يظهر فيها بروح عالم الثرع الذي يدعو إلى الإقلاع عن المعاصي والإسراع إلى التوبـة

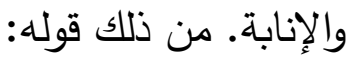

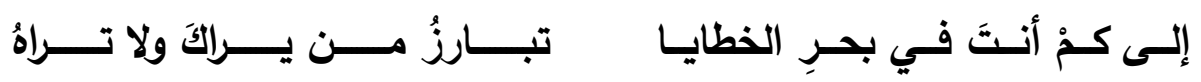

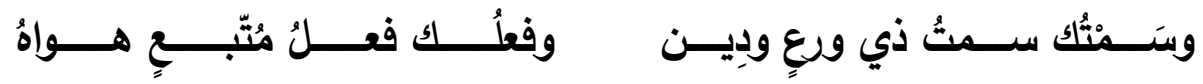

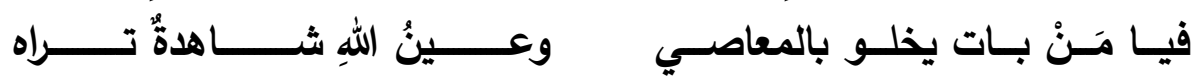

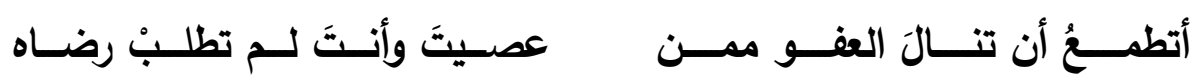

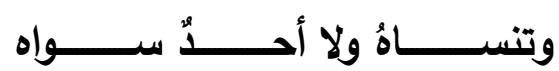

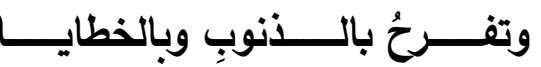

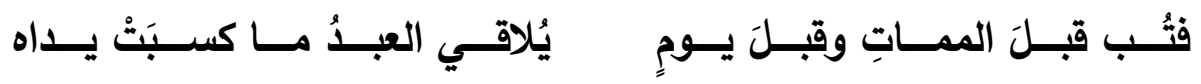
وهو شعر أقرب مـا يكون إلى شعر الزهد والدعوة الذي حمل لواءه أبو العتاهية، فلا نكاد نلمح فيه غير المعاني الإسـامية المطروقة، ومع ذلك فهو لا يخلو من إشارة صوفية ظهرت في البيت الرابع " ولا أحدٌ سواه" بما يدل على وجود هذا الاستعداد الصوفي بداخل نفس الثاعر، سواء أقال هذه المقطوعة في بدايـة سلوكه الصـوفي الذي يبدأ عادة بالزهد، أم قالها بلسـان الفرق وهو 
لسـان الصـوفي حينمـا يرجـع إلى صـوابه وبشـريته فيعي مـا يقول، ويخاطب الخلق بلسانهم ليبين لهم سنن الطريق. ونلاحظ في هذا الثـعر الثـرعي -إن جـاز التعبيـر - أن الحـلاج صـاغه بأسـلوب معهود لمثل هذه المعـاني الإسـلامية المطروقـة، فكلماتـه وعباراتـه وصوره ومقارناته هي من النوع المطروق المتداول. وقد يقترب في هذا النوع من الشعر إلى المعاني الصوفية بصورة تصل إلى

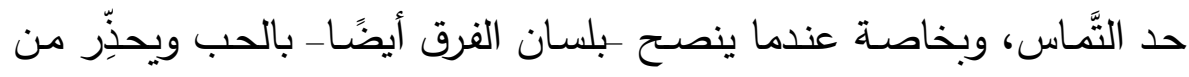
البعاد والجفوة. يقول:

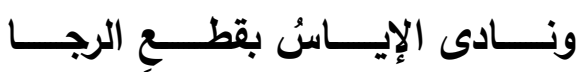

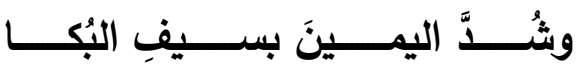

علـــى حــــرٍ مِــنْ كَمــينِ الجَفــــا

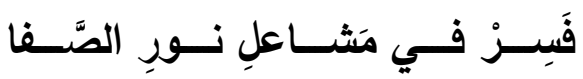

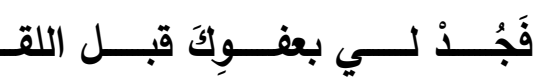

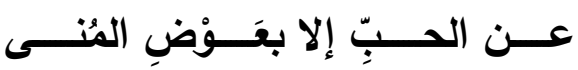

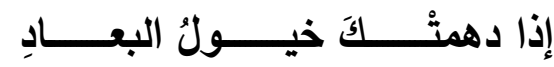

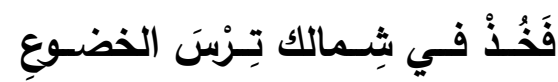

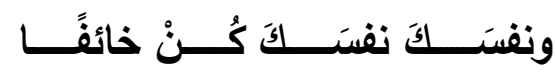
فـإنْ جــاءكَّ البحــر فــي ظُلمـــة

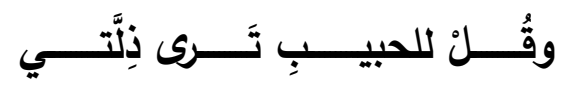

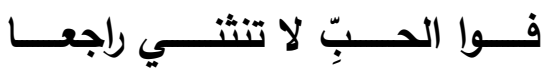

والثاعر هنا ينتقل إلى درجة أسمى، وهي درجة المحبة. بيد أنه لا يزال في نطاق الشرع فهو لم يتقلب في أحوالها الصوفية من سكر وهيام وغزل، ولكنه ينصح فقط بالسير في نور الصفاء وطلب العفو، لتبدأ رحلة المحبة وتتحقق

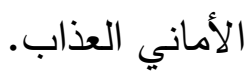

وعلى مستوى الصياغة الشعرية نجد أن الشاعر كذلك انتقل إلى درجة من خصوصية التعبير واختراع الصور الفنية غير المطروقة في مثل هذه المعاني كصـورة خيـول البعـاد في البيـت الأول والصـورة المفارقـة في البيـت الثاني، 
ونقصد بالمفارقة هنا أن الكلمات التي كونت الصورة توحي بالقوة والضعف في آن واحد، قوة العزيمة والإرادة، وضعف العبودية.

فالقوة في: خذ ترسي - شد اليمين بسيف. والضعف في: الخضوع والبكاء. إنه نمط غير تقليدي في التأليف بين مكونات الصورة الواحدة.

ومن مقطوعات الزهد الواضحة والتي تحمل نظرته عن الدنيا وزينتها قوله:
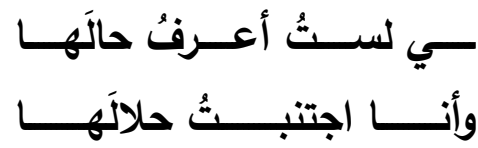

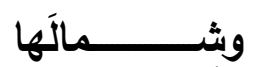
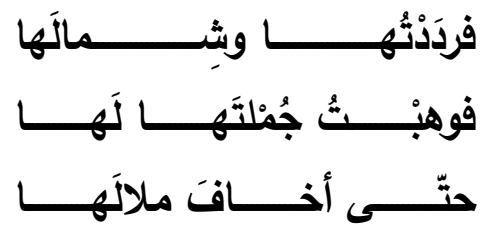
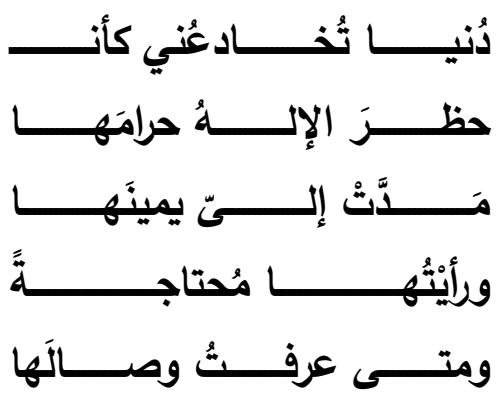

فهو كسائر البشر يعاني من خداع الدنيا، ولكنه بما أوتي من عزيمة ويقين قد زهد في ملذاتها بل إنه اجتب الحلال أيضًا حتى لا يجرّه إلى الحرام. وهذا من باب الورع الذي ينتهجه الزهاد والعباد. والزهد في الدنيا مطلب شرعي "ازهد

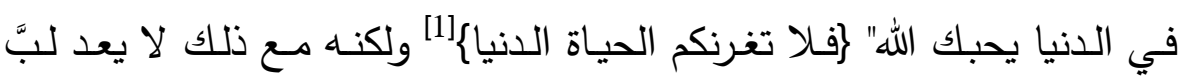
التصوف بل هو بداية المريد الذي لا يلبث أن يرقى في درجات من المقامات العليا ثم يعود بعدها إلى الحياة الدنيا يتعاطاها برؤيسة أخرى هي شهود مولاه في كل ذرة فيها "البقاء بعد الفناء".

ونراه يصرح بحالة الزهد هذه في موضع آخر حينما يقول مخاطبًا نفسه:

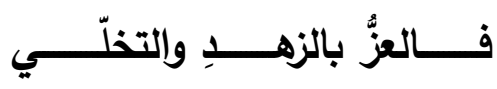
عليــكِ يــا نفـــُ بالتســلِي 
والحلاج شأنه في ذلك شأن المتصوفة الأوائل يرى أن الشريعة هي مفتاح الدخول إلى عالم التصوف، لذا نجد طائفة من أشعاره تجري على مثل هذا النَّسق الشـرعي، كالنُّــح والإرشـاد والتوبِّـل والابتهال. وهذه المقطوعـات قد يكون قالهـا في مرحلـة معينـة مـن مراحل حياتـه الصـوفية، وقد يكون قالها تحصُّنا من الاتهام الذي قد يوجه إليه أمام تلك الشطحات التي تصدر عنه في حالة لا يملك معها ضـبط كلماتـه وعباراته بمراسم الثريعة. وعلى أيـة حسال فمعظم أخبار الحـلاج تدل على أنـه كان في حياتـه زاهدًا ناسكًا، ففي كتاب التعرف لمذهب أهل التصوف لأبي بكر محمد بن اسحق الكلاباذي المتوفي سـنة 380هـ وهـو مـن المصــادر الأولـى للتصـوف الإســامي، يـذكر أن أبـا المغيث كان "لا يستتد ولا ينام على جنبه، وكان يقوم الليل، وإذا غلبته عينه قعد ووضع جنبيه على ركبته فيغفو غفوة، فقيل لله ارفق بنفك، فقال والله ما رفق الرفيق بي رفقا فرحت بـه، أمـا سمعت سيد المرسلين يقول: أشد الناس بـلاء الأنبياء ثم الأمثل فالأمثل"[2]. ويقول أيضًّــا "وسمعت بعض مشـايخنا يقول: سمعت محمد بن سعد يقول: خدمت أبا المغيث عشرين سنة فما رأيته أسف على شيء فاته، أو طلب شيئًا فقده"[3]. فإذا أضفنا إلى ذلك استثهاد أبي القاسم القشيري بكلامه في الرسالة القشيرية عند حديثه عن أصول التوحيد عند الصـوفية4 علمنـا مدى مـا يتبوؤه الحـلاج من مكانـة في عالم التصـوف ترس الشرعي على الرغم مما نسب إليه من شطح. 


\section{الإنسان (الناسوت والللاهوت):}

من القضـايا النظريـة التي تناولها الحـلاج، قضية الإنسان، الجسم والروح، تلك القضية المعقدة التي شخلت الفلاسفة والمفكرين منذ قديم الزمان، وهي القضـية ذاتها التي شـل بها كثير من علمـاء الأديان، وحاولوا من خلالهها تفسير النبوة والوحي والرسالة. وكون النبي بشرًا يوحى إليه. يقول الحلاج في إحدى مقطوعاته الثهيرة:

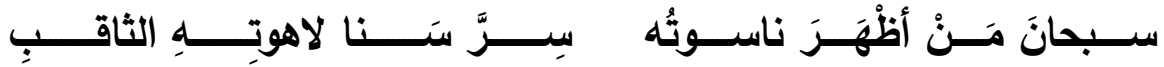

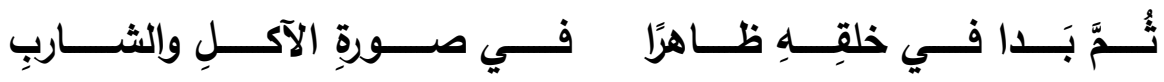

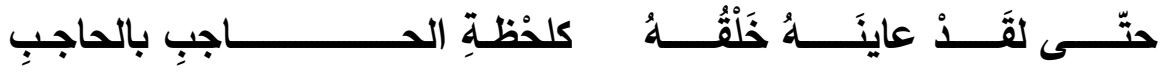
وهو في هذه الأبيات يشرح نظريته في طبيعـة الإنسـان ومـا يحمل مـن خصائص النفس البشرية (الناسوت) والخصائص الإلهية (اللاهوت)، والناسوت واللاهوت من المصطلحات التي تداولتها المسيحية لتحليل طبيعة المسيح عليه السَّلام: صورته الإنسانية (الناسوت) وصورته الإلهية (اللاهوت)، وفي هذا ما يدل على اطلاع الحلاج على ثقافات أهل الديانات الأخرى. ودراسـة تركيب الجملة في هذه الأبيات قد تفيد في بيان دلالاتها الدقيقة، فكلمـة "ناسوته" هنـا وقعت فـاعلًا مسندًا إليه، بمعنى أن الإنسـان بإمكانـه أن يُظهر سرَّ الجانب اللاهوتي فيه من خلال تعبده وتحنثه وارتقائهه حينما يترفع عن الآثار المادية. ثم بدا في خلقه ظاهرًا أي بعد رحلة الارتقاء يظهر السر اللاهوتي في الصـورة البشرية العادية (في صسورة الآكل والثـارب) فهو سر كامن في هذه الصورة. وهذا مـا يعبر عنـه الصـوفية بقولهم: "أن يموت المرو 
بنفسه ويحيا بالله"[5] غير أن تعبيراتهم تبدو مغلَّة بغلاف شرعي، أما الحلاج فكان أقرب إلى التصريح؛ حيث يقول: ثم بدا في خلقه ظاهرًا في صورة الآكل والثارب أي هي مرحلة ما بعد العرفان، حينما يرجع العارف باله في الخلق بشرا مثلهم بأكل ويشرب. فهو مثلهم بناسوته، وهم خلقه بلاهوته. مع أن كلا منهم يكمن في ناسوته اللاهوت الواحد الذي إن تجلى تم الوصول والعرفان والتوحد لكل واحد منهم كما تم لهذا العارف، فالحقيقة واحدة، وفي الإنسان، أو في هذا الناسوت، يكمن سر اللاهوت. أو كما يقول الثاعر : وفيـك انطــوى العـالمُ الأكبــز

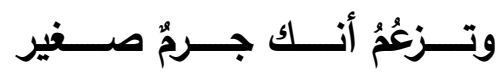

وعلى الـرغم مسن شـهرة الأبيـات السـابقة، وشـهرة نسـبتها للحـلاج، إلا أن التصـريح الواضـح فيهـا بـلا هويـة الإنســان قد جعل بعض الصـوفية الأوائل المدافعين عن الحلاج - قليل ما هم- يشككون في نسبتها إليه. فيروى عن أبي عبد الله محمد بن خفيف المتوفى سنة 330هـ وهو صوفي كبير ذكره السلميّ في طبقاته والقشيري في رسالته وغيرهم، أنه سئل عن معنى هذه الأبيات، وكان مـراد السـائل الغمز إلى الحـلاج حيث يعرف أن ابن خفيف كان من أنصاره، فقال ابن خفيف: على قائلها لعنة الله. فقال السائل: هذا للحسين بن منصور فقال: إن كان هذا اعتقاده فهو كافر ، إلا أنـه لم يصـح أنـه لـه، ربما يكون مقولًا عليه. [6] ويؤيد كلام ابن خفيف ما ورد أيضًا في أخبار الحلاج عن أحمد بن فاتك خادمـه وصـاحبه أنـه قال: قال الحـلاج: "من ظن أن الإلهيـة تمتزج بالبشرية أو البشرية تمتزج بالإلهية فقد كفر، فإن الله تعالى تفرد بذاته وصفاته عن ذوات الخلق وصفاتهم، فلا يشبهرم بوجه من الوجوه، ولا يشبهونه

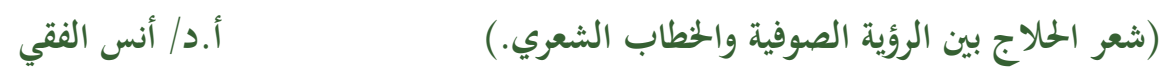


بثيء من الأشياء. وكيف يتصسور الثبه بين القديم والمحدث. ومن زعم أن البارئ في مكان أو على مكان أو متصل بمكان، أو يتصور على الضمير، أو يتخايل في الأوهام، أو يدخل تحت الصفة والنعت فقد أشرك"[7]. فإن صـح هذا عن الحلاج فسيكون ما ورد بشعره -إن صحت نسبته إليه- إما شطحات في حالة ولهٍ صوفي، أو مستوى معينًا من الفهم في مرحلة معينة من مراحل حياته الصوفية.

ومن المعروف أن الموقف الثُعري أو التجربـة الثعرية تجعل الثاعر في حالة أخرى غير تلك التي يلقي فيها مبادئ ونظريات قابلة للحوار والمناقثـة. فالنص النثري السابق المنسوب للحلاج والذي رواه أحمد بن فاتك نص مقبول في الشرع كأنه جاء ليشرح العقيدة الإسلامية في حين أن من يقرأ قول الحلاج:

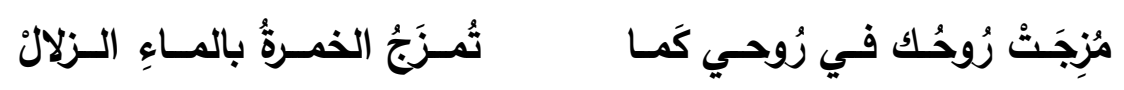
فـــإذا مَسَّــك شَـــيءُ مَسّــني يجد هوة ظاهرة بين كلامه النثري ونصه الشعري، فإذا ذُرس النص الشعري وفهم بالذوق الفني أمكن تأويله إلى معانٍ وجدانية صوفية وليس اعتقادًا محضًا مفروضًا على الناس.

فالإنسان عند الحـلاج هو "الناسوت" كما ذكر سابقًا، أي هو ذلك الهيكل الجسدي المادي. ولكنه يحمل في صميمه لطيفة إلهية صمدية هي اللاهوت، وعند الموت موت النفس وموت الجسد تعود الروح إلى مكانها الأصلي من حيث صدرت، ويبقى الهيكل رميما تحت التراب يقول: 


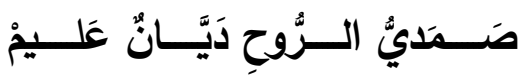

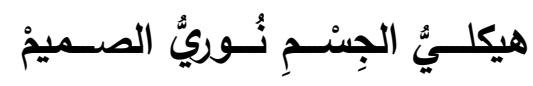

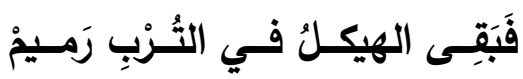

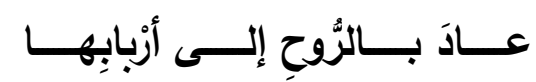
فلا سبيل لهذا الإنسان بأن يُجمع على مولاه إلا بالموت، والموت كما قلنا موت النفس، أي محو صفاتها تماءًا، أو موت الجسد، وهو الموت الطبيعي الذي ترحل فيه الروح إلى بارئها. ولأن الصـوفية يسلكون عادة السبيل الأول الذي هو "أن يموت المرو بنفسه ويحيا بربـه"، طلب الحـلاج هذا الموت، بل استعجله فسماه قتلا، لأن القتل استعجال للموت. يقول الحلاج:
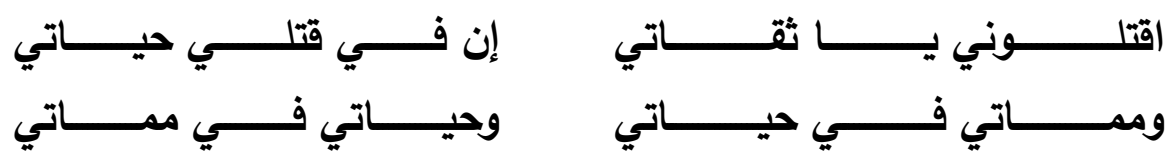

وهنـاك نـوع آخر مـن المـوت لا يعنـي بـه الحـلاج مـوت الـنف أو مـوت شهواتها، بل يعني به الموت من شدة الحب أو شدة الهجر، وهذا سنعرض لله إن شـاء الله عند حديثنا عـن الجوانب الوجدانيـة في إطـار العشـق الصـوفي وتداعياته.

\section{وحدة الأديـن عند الحلاج:}

يقول الحلاج في إحدى مقطعاته:

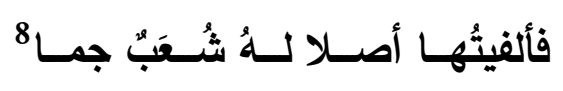
يصــاٌٌ عـن الوصـلِ الوثيـقي وإنّمـــا

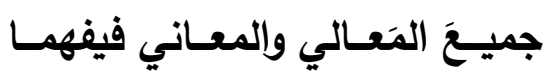

تَفَكِرتُ في الأديانِ جدَّا مُحققًا

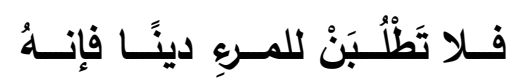

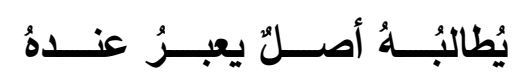
وهذه المقطوعـة تمثل نظرة الحـلاج لجميع الأديـان وهي تعبر عن مبـأ صوفي صيغ بعبارة مختلفة وهو "ألا معبود في الحقيقة إلا الله" وهذا المبدأ وإن 
كان له محاذير لاى علماء الشرع إلا أن هناك من يبرره بأن المقصود به هو العبادة القهريـة، عبوديـة الخلق لربهم الخـالق والتي عبر عنها النص القرآني بقوله \}وإن من شيء إلا يسبح بحمده\{[9] وقوله \}ولله يسجد من في السموات والأرض طوعًا أوكرهاج[10]. وهذا التبرير - -عند علمهاء الشرع- لا ينفي صفة الكفر عن غير المؤمنين بالدين الخاتم، والنبي الخاتم، حيث هو الجامع لكل ما سبق من الأديان. أما عند الحلاج، فالأمر أكثر سعة، فالأصل هو الوصل، وعند الاتصال بالحق تُنال جميع المعالي وتُفهم جميع المعاني. وقد وردت الأبيات السـابقة في أخبار الحـاج في سياق خبر رواه عبد الله بن طاهر الأزدي قال: كنت أخاصم يهوديا في سوق بغداد، وجرى على لفظي أن قلت له: يا كلب، فمر بي الحسين بن منصور، ونظر إليّ شزرًا وقال: لا تُنبح كلبك، وذهب سريعًا، فلما فرغت من المخاصمة قصدته، فذخلت عليه، فأعرض عني بوجهه، فاعتذرت إليه فرضي ثم قال: يا بني، الأديان كلها لله عز وجل، شغل بكل دين طائفة لا اختيارًا فيهم، بل اختيارًا عليهم. فمن لام أحدًا ببطلان ما هو عليه فقد حكم أنه اختار ذلك لنفسه، وهذا مذهب القدريـة، والقدرية "مجوس هذه الأمة"، واعلم أن اليهودية والنصرانية والإسلام وغير ذلك مـن الأديـان هـي ألقـاب مختلفـة وأسـام متغـايرة، والمقصـود منهـا لا يتغيـر ولا يختلف ثم قال: تفكرت في الأديان .... الأبيات. وقد رأى الدكتور شوقي ضـيف أن الحـلاج هو الذي وضـع في التصـوف الإسـلامي فكرة أن الأديـان جميعًا تؤدي إلىى الله، وأنهـا فقـط تختلف في شعائرها، ولكنها تتحد في الغاية.[11] 


\section{سطوة الأقدار ووجوب التسليم:}

من الأبيات المشهورة التي تنتسب للحلاج قوله:

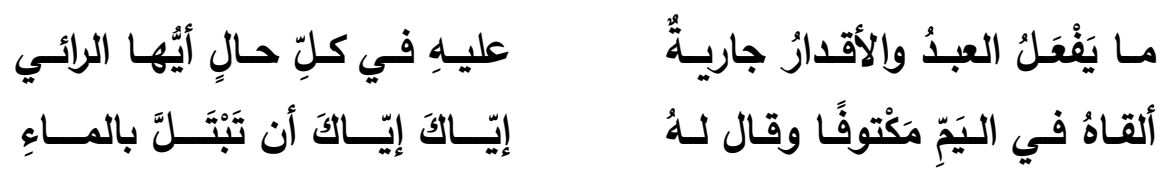

وهذان البيتان يمثلان رؤيسة نظريـة لموضوع الإنسان والقدر ، فالحلاج يرى

أن العبد لا يملك أمام الأقدار حولا ولا قوة ذلك لأنها جارية عليه لا محالة منذ

الأزل. فهو عبد ليس أمامـه إلا تسليم العبوديـة. والمدقق في مضمون البيت

الثاني وأبعاده الدلالية يجد أن الحلاج يغز إلى قضية الأمر والنهي، أو قضية

التكليف الإلهي المنوطة بالإنسان، والواضح هنا أنه يرى أن الإنسان قد يكلف

شرعيًّا بأمور معينة، جرت عليه المقادير بعكسها. فما الذي يملكه المكتوف لهـ

الذي ألقي في اليم حتى يستطيع أن يتجنب بلل الماء. وقد يفهم من هذا أن

الحلاج معترض أو ناقم على هذا الوضع، ولكن هذا ليس مقصوده في أغلب

الظن، فالذي يقصده الحلاج هو أن العبد مـا عليه إلا التسليم والسكون تحت

مجاري الأقدار ؛ حيث يلجأ بعجزه وانكساره إلى ربـه طالبا العفو والمغفرة وهنا

$$
\text { تحديدا يتحقق معنى العبودية[12]. }
$$

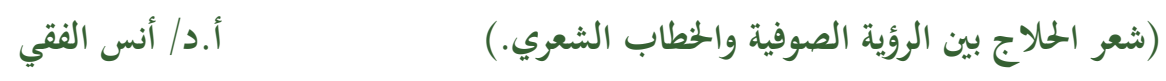


حيرة العقل:

يقول الحلاج معبِرًا عن حيرة الخلائق أمام معرفة الله تعالى:

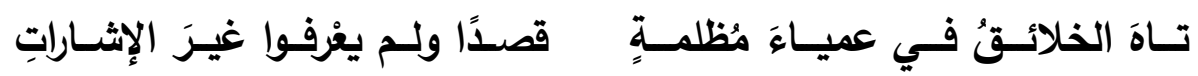

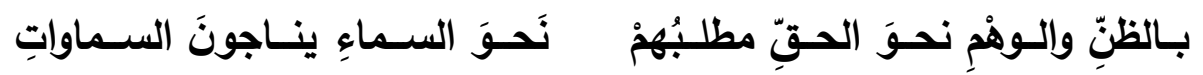

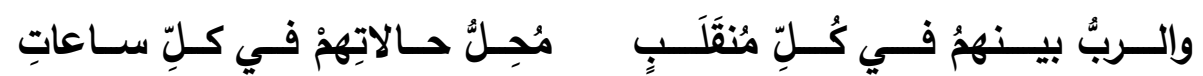

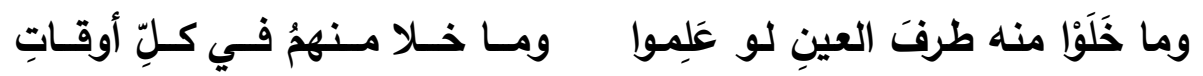
فهو يرى أن عامة الناس قد تاهو في ضـلالهم حينما قصدوا ربَّا معينًا في السماء محدودًا في مكان، لأن الله بينهم في كل حالاتهم، بل هو الذي يقلبه في أحوالهم. وكلامه هذا له مستند شرعي في الدين كقوله تعالى: روهو معكم أينما كنتم\{13 وقوله \}ونحن أقرب إليه من حبل الوريد\{14 فوهو الذي في السماء إله وفي الأرض إلـه|15 أي أنـه نفى الجهة والتحديد. ولكنـه مـع هذا كله يرى كثيرًا من الناس وبعض رجال الثرع أمامهم يقولون إن الله في السماء؛ لذا فهو يؤكد على هذه النقطة في أكثر من موضع فنراه يقول:

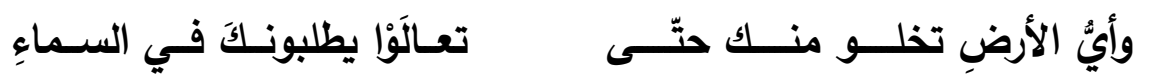

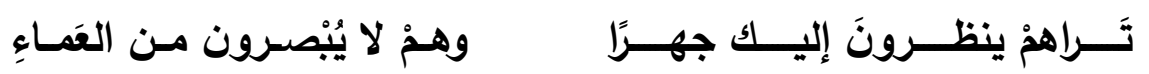
فهو سبحانه وتعـالى قد جَلَّ عن أن يُحَدِد بمكان أو أن تكون لـه جهـة معينة، حيث هو الوجود الحق بأسره، وهو الظاهر الذي ينظرون إليه ولكنهم لا يبصرون بسبب ذلك العمى الذي أصاب بصائرهم. 16 


\section{المعرفة والعلم عند الحلاج:}

يؤكد الحسلاج في أكثر من موضـع من شعره ونثره على أن العلم علمان: علم مطبوع وعلم مكتسب؛ أو بصيغة أخرى علم الحقيقة وعلم الثريعة، ولا غنى لأحدها عن الآخر فهما من مشكاة واحدة، ولكن هذا لسان وذلك لسان آخر • يقول في إحدى قصائده:

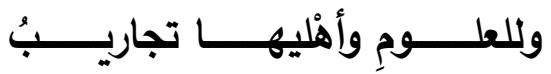

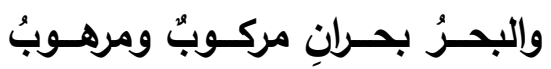

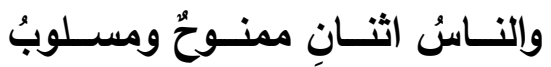

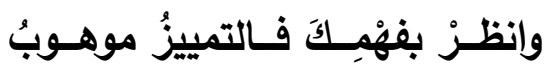

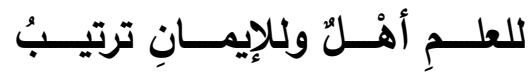

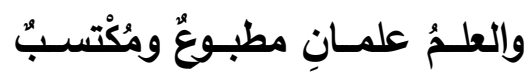

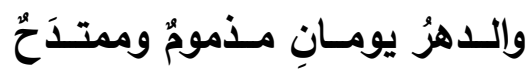

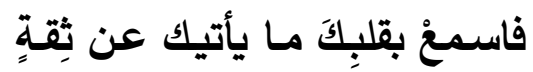

فبداية المنظومة كما نرى شرح وتوضيح لفكرة معينـة يريد أن يوصلها إلى

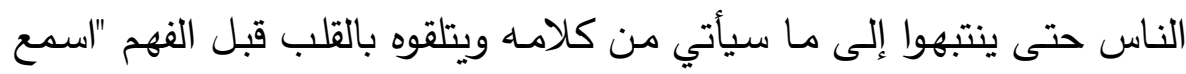
بقلبك - وانظر بفهمك" ولذلك نراه بعد ذلك يبدأ في سرد تجربته الصوفية بعد بند هذه المقدمة النظرية فيقول:

لـهُ مسراقٍ علـى غيـري مَصـاعيبٍ

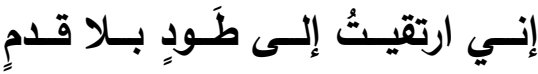

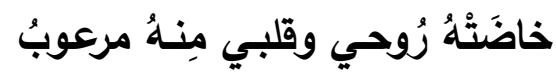
وخضتُ بحرًا ولمّ يرسبْ بـه قدمي

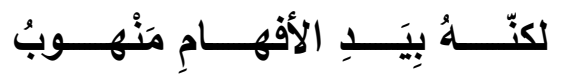

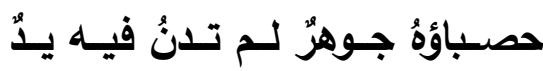

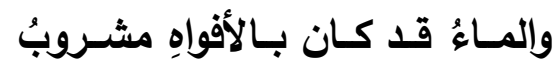

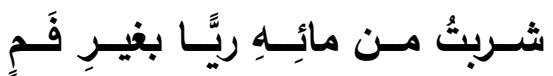

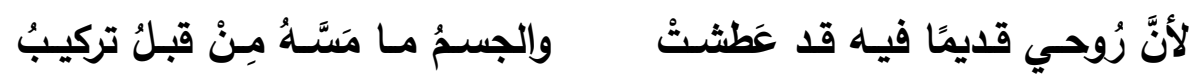
وهذه التجربة التي يُرْفُهُها الحلاج بعد مقدمته النظرية إنما هي رحلة العودة إلى الأصل الذي انبثقت منه الروح قديما، وقد وصل من خلالها إلى حالة من الري والنشوة بعد جهاد يشق على غيره، إنها حالة التوحد الأزلي مـع الحبيب 
الأول قبـل نشـأة الأجسـام والمـادة، وسـنعرض لهذه المعـاني عند حديثنا عن الجانب الوجداني. ويسمي الحـلاج التحدث بعلم الشريعة أو بمـا يوافق الثريعة "لسـان العلم" ويسمى الحقيقة "لسان الغيب" يقول:

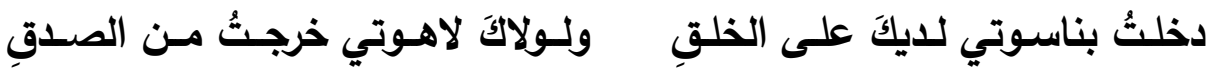

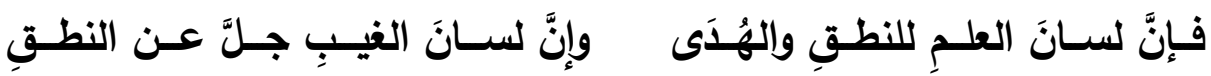
فهو بناسوته إنسان، بشر ، يحدث الخلق بلسان العلم، ولاهوته هنا هو ميزان الصدق الذي يمنح هذا الناسوت مصداقيته بين الناس، ويكون ذلك بلسان العلم الذي هو للنطق والهدى. أمـا لسان الغيب الذي هو الحقيقة المطلقة فقد جل عن النطق، حيث لا يعلمـه إلا أهلـه بالإشـارة لا بالعبـارة. فالحقيقـة لا يمكن صياغتها في قوالب اللغـة، فـإن حصل ذلك تحولت الكلمـات إلى شطحات تحتاج إلى تأويل ينأى بصاحبها عن الوقوع في التهم الشرعية. يقول الحلاج في طاسين بستان المعرفة: "مـا صـحّت المعرفة لمحدود قط، ولا لمعدود ولا لمجهـود ولا لمكدود" ويقول أيضًـا: "الفهم طـول وعـرض، والمطالعـات سـنن وفرض، والخلق كلهم في السماء والأرض، وليس للمعرفة طول ولا عرض، ولا تسـكن في السـماء والأرض، ولا تسـتقر في الظـواهر والبـواطن مثل السـنن والفـرض"[17]. ويقول في طاسـين الفهم "أفهـام الخلائق لا تتعلق بالحقيقـة، والحقيقة لا تليق بالخليقة، الخواطر علائق، وعلائق الخلائق لا تصل إلى الحقائق، والإدراك إلي علم الحقيقة صسب، فكيف إلى حقيقة الحقيقة؟ الحق وراء الحقيقة، والحقيقة دون الحق"[18].

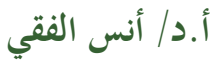

(شعر الحلاج بين الؤية الصوفية والحطاب الشعري.) 
ويؤكد الحلاج على قضية قصور العقل البشري في معرفة الحق فيقول:

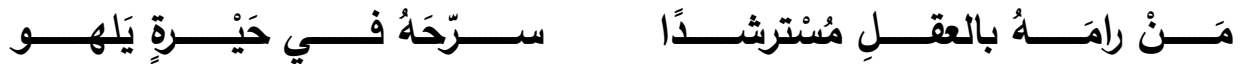

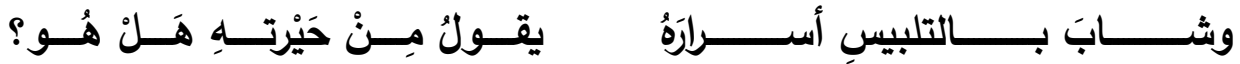
فالعقل في نظره عاجز عن معرفة خالقه المعرفة التامـة؛ حيث إنه مخلوق محدث، ليس في وسعه أن يحيط علمًا بالخالق القادر • وقد استشهد الكلاباذي بهذين البيتين من شعر الحلاج في باب معرفة الله تعالى وهو الباب الحادي والعشرون من كتاب التعرف، وقدم لهما بقوله: "أجمعوا على أن الدليل على الله هو الله وحده، وسبيل العقل عندهم سبيل العاقل في حاجته إلى الدليل؛ لأنـه محدث، والمحدث لا يدل إلا على مثله. ثم يُرْدف بعد ذلك قصيدة من قصائد الحـلاج دون التصـريح باسـمه، وذلك ربمـا يكـون بسبب مـا أشيع حولـه مـن شطحات، المهر أنه يستشهد بشعره في باب معرفة الله تعالى ناعتا إياه بأرقى النعوت الصوفية فيقول: وقال بعض الكبراء من أهل المعرفة[19]:

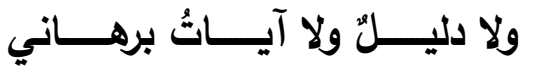
قد أزهـرتُّ في تلاليهـا بِســلطانِ

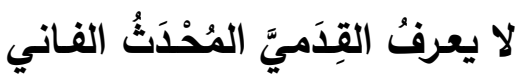

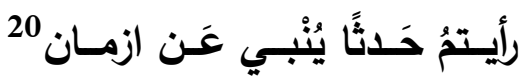
مِنْ شاهدِ الحقِّ في تنزيـلِ فُرْقِانِ

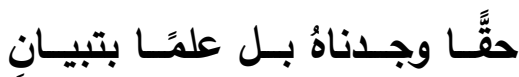
هـــا توحُّــُ توحيــدي وإيمــاني ذوي المعـارفِ في سـرِّ وإعـلانِ بنـي التجـانُسِ أصـحابي وخِلانسي
لـم يبـقَ بيني وبسينَ الحقِّ تِبيـاني

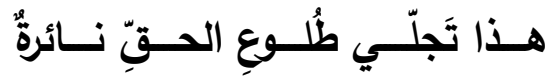

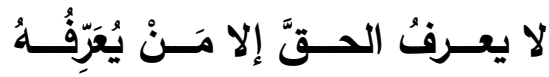

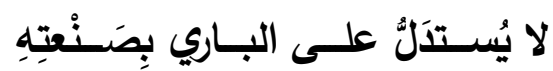

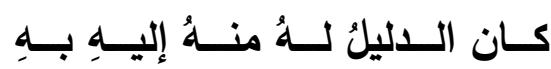

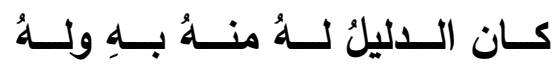
هذا وجـودي وتصـريحي ومُعْنَقَدي

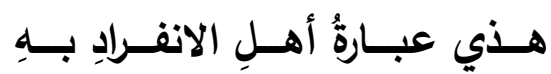
هـــا وجـودُ وجـودِ الواجــدين لــهُ 
والأبيات كمـا نرى- تبدو وكأنها تسوق رؤيسة نظريـة في المعرفـة، وفي العجز عن معرفة الحق إلا بالحق "لا يعرف الحق إلا من يُعَرَّفُهُهُ" فالاستدلال

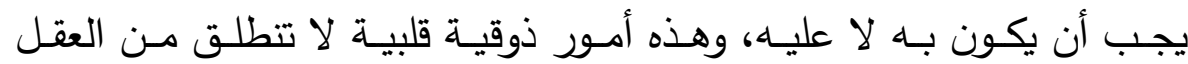
الإنساني بل من الإيمان الروحي المسبق أو كما يردد الصوفية "إنا لننظر إلى دهلى

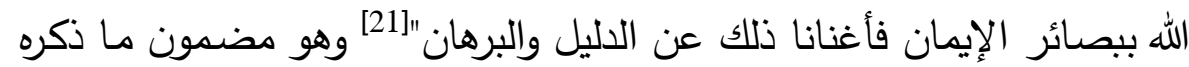
الثاعر في البيت الأول. والثـاعر في الأبيات السابقة يصرح تصريحًا شرعيَّا وكأنـه يـلي بشهادته أمسام الناس "هذا وجودي وتصريحي ومعتقدي" أو كأنـه يبرئ نفسـه ممـا نسب أو قد ينسب إليه، ليس هذا فقط بلـ إنه يبرئ أتباعـه وأمثاله من الصوفية أيضًا، فينسب إليهح ما نسبه إلى نفسه من الإيمان الكامل بالدليل الروحي لا الدليل العقلي.

ذوي المعسـارفِ فـي سـرِّ وإعـلانِ

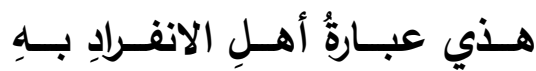
بنـى التجـانسِ أصـحابي وخلانسي

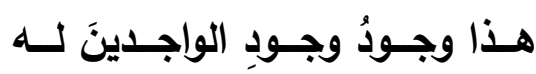

\section{الصحبة في طريق التصوف:}

مـن المبادئ الصـوفية التي تظهر مـن المنظومـات النظريـة للحـلاج مبـدأ الأخوة في الطريق الصوفي، وقد ظهر ذلك في الأبيات السابقة التي ربط فيها اعتقاده باعتقاد إخوانـه وأمثاله من الصـوفية، والذين نعتهم بأهل الانفراد بـاله وذوي المعارف وكذلك نعتهم بأنهم بنو التجانس أصحابه وخلانـه. والصسوفية على وجه الخصوص لهم رؤيسة خاصـة في الترابط والتواصل بين الناس، وهذه الرؤية تتبثق من المشكاة القرآنية بل من الدين بصفة عامة، فالإنسان خليفة الله في أرضه، والناس جميعًا مخلوقون من نفس واحدة، بيد أن العوارض النفسية

(شعر الحلاج بين الؤية الصوفية والحطاب الشعري.) أ.د/ أنس الفقي 
والثهوات المادية تُوهم الإنسان بالأنانية، وتدعوه إلى مهاوي الشر والفساد، فإذا طهّر نفسه من هذه الأوهام المادية الطينية، وارتقى بعبوديته إلى سماء الروح، انكشف لله الأمر ، وعرف نفسه، فعرف ربّه، وعرف أن الكل منـه وإليه، فمن أدرك هذا اتصل بمن وصل قبله، وصاروا جميعًا نفسًا واحدة.

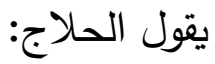

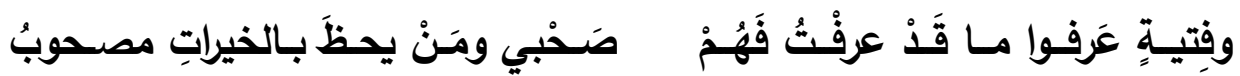

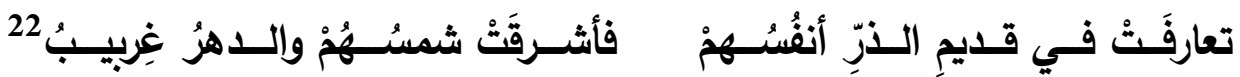
وهو هنـا يشير إلى ذلك التعـارف الأزلـي في عـالم الذر حيث تعارفت الأرواح قبل خلق الأشباح، وشهدت للحق سبحانه بالوحدانية والربوبية. ونظريـة الذر هذه لها أساس في القرآن الكريم؛ حيث قال تعالى روإذ أخذ ربك من بني آدم من ظهورهم ذريتهم وأشـهدهم على أنفسهم ألست بربكم قالوا بلى شهدنا 23.... وعلى الرغم من انقسام رجال الصوفية المعاصرين للحلاج عليه إلا أن كثيرًا منهم ربمـا رده أو رد كلامـه دريًا للشبهات فقط أمسام أهل الثريعة ومن يتبعهم من العامة، مع إضمار الاحترام والتوقير في الباطن. يقول السلمي في طبقاته: "ردّه أكثر المشايخ ... وَقَبَلَهُ من جُملتهم أبو العباس بن عطاء، وأبو عبد الرحمن محمد بن خفيف، وأبو القاسم إبراهيم بن محمد آباذي"24 أما من ردّه، فعلى رأسهم أبو القاسم الجنيد الملقب بشيخ الطائفة، على الرغم من تتلمذ الحلاج على يديه، فقد صحبه الحلاج في بدايته، ووقع بينهما حوار مشهور ، زجره فيه الجنيد، فخرج من حلقته صامتًا. 25 وكل هذا لا يفيد على وجه القطع عدم اعتراف الجنيد به، فربما يكون الموقف من قبيل التربية الصوفية فقد كان 
الحلاج شابَّا مبتدئًا. أما أقوال الجنيد السلبية فيه بعد ذلك، فقد تكون من باب حفظ الثريعة والغيرة عليها من الشطحات الصوفية التي تفوه بها الحلاج، ولم يتحمل كتمانها والتي قد تضر بالصوفية عامـة. ومـع ذلك فقد كان من كبار رجال الصوفية في عصره وبعد عصره من يجاهر باحترامه ومحبته، كأبي عبد الله محمد بن خفيف المتوفى سنة 330هـ الذي زاره في سجنه، وأثنى عليه قائلًا: الحسين بن منصور عالم رباني 26، وكذلك أبو يعقوب إسحق النهرجوري المتوفى سنة 320هـ، وخادمـه أحمد بـن فاتك، وكذلك نصـر القشوري الذي ري استأذن الخليفة في بناء بيت لله بالسجن، وقاضي القضـاة أبي بكر بن الحداد المصري 27. وأخيرًا صديقه الحميم الذي توفي في العام نفسه الذي توفي فيه الحلاج 309هـ وهو أبو العباس أحمد ابن عطاء الآدمي 28 وهو الوحيد الذي خُصّ في شعر الحلاج، فقد وردت بعض الأبيات المنسوبة للحلاج مشفوعة بمقدمة نثرية موجهة إليه بما نصـه: كتب الحلاج إلى أبي العباس بن عطاء: أطال الله لي حياتك، وأعدمني وفاتك، على أحسن ما جرى به قدر، ونطق به خبر ، مع ما لك في قلبي من لواعج أسرار محبتك، وأفانين ذخائر مودتك، ما لا يترجمه كتاب، ولا يحصيه حساب، ولا يفنيه عتاب، وفي ذلك أقول:

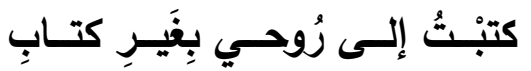

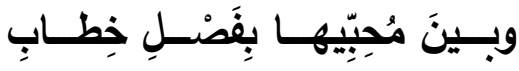

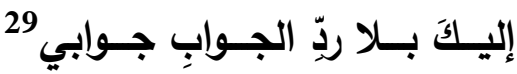

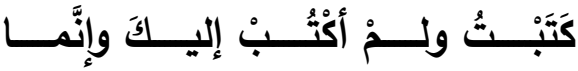

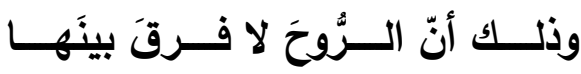

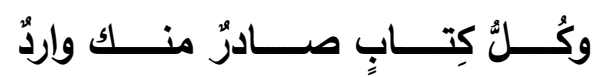
وهذه الأبيات توضـح مـا أشرنا إليه سـابقًا من ذلك التواصل الروحي بين الصديقين، فهي صداقة غير عادية، إنها توحد تام، إنها النفس الواحدة التي 
يمكن أن تتواصـل بـلا حـروف ولا كلمـات، على البعد والقرب، إنها الأخـوة الصوفية عند الحلاج.

وفي أخبار الحلاج أيضًا تأتي رواية أخرى مشفوعة بالشعر عند الصديقين: الحلاج وابن عطاء: "كتب الحلاج إلى أبي العباس بن عطاء من السجن: أما بعد، فإني لا أدري مـا أقول إن ذكرت بـرَّكم لـم أنتهـ إلى كنهـه، وإن ذكرت

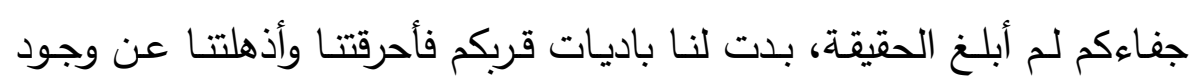
حبكم، ثم عطف وألف ما ضيع وأتلف، ومنع عن وجود طعم التلف. وكأني وقد تخرقت الأنوار وتهتكت الأستار ، وظهر ما بطن، وبطن ما ظهر ، وليس لي من خبر ، ومن لم يزل كما لم يزل، وختم الكتاب وعنون بقوله:

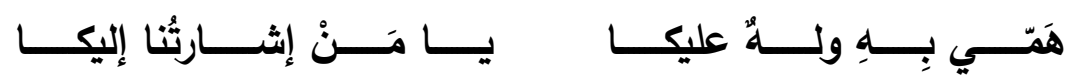

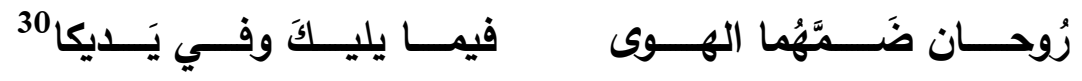
فهو يؤكد في هذين البيتين على التوحد بين الصديقين في المحبة،في محبة

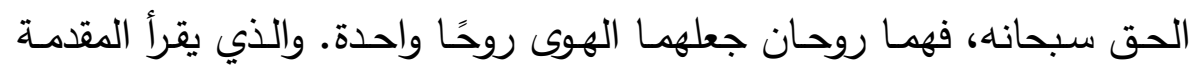
النَّرَيـة يجدها موجهة إلى الحبيب الأعلى بلسـان الصديقين، فكأنه كتبها إليه

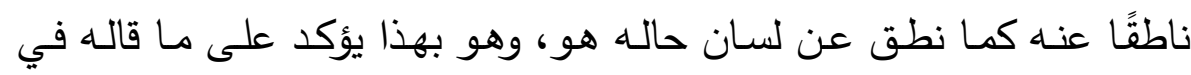
مقطوعته السابقة:

وذلك أن الروحَ لا فرقَ بينها وبينَ مُحبيها بفصلِ خطاب

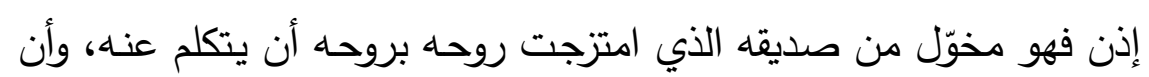
يعبر عن حاله، فالحال واحدة، والروح واحدة، والحبيب واحد. وللحلاج في شعره منطق معين يرى أنه حكمة خاصة لا يفهمها إلا أهلها؛ ولذلك نراه يكرر مدحه لهؤلاء الناس الذين يفهمون مراده ويقتتعون بحكمته، وإن

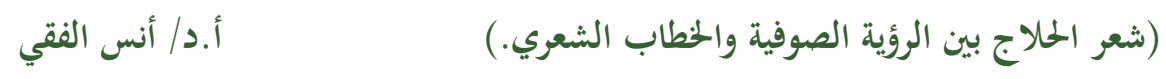


لم يكن هؤلاء الناس هم جُل الصـوفية بل بعضهم، المهم أن لـه رؤيسة خاصـة فهو يرى مثلًا أن كتمان الحب خطر على صاحبه، وأن غاية الأمن أن تدنو من الحذر يقول:

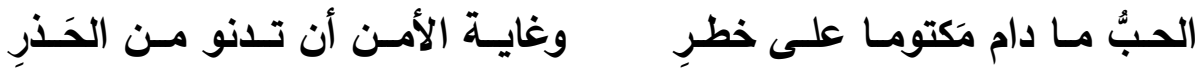

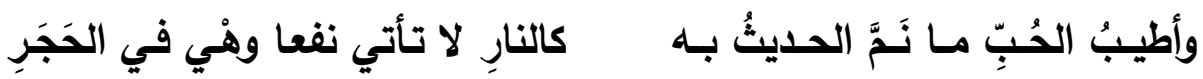
وهو في الوقت ذاته لا يبيح إفثـاء السر، فهناك فرق بين إفثـاء الحب وإفشاء السر، فإفثاء الحب في رأيه مطلوب أما إفشاء السر - أي سرّ ما علمه من الوصل والكثف- فهو غش وسبب للطرد والبعد يقول:

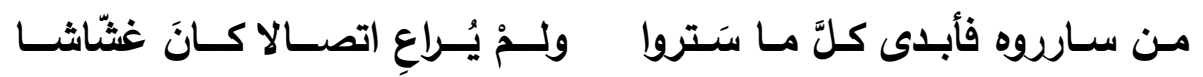

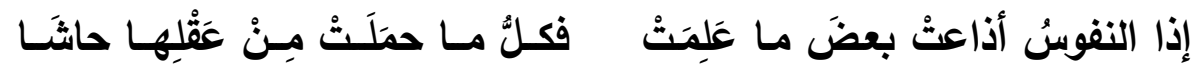

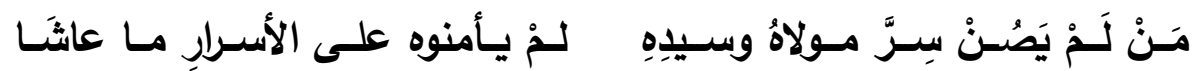
ومع هذا كله فهو يعترف بأنه نمَّ بالسر الذي اطلح عليه لذا فهو يحكم على نفسه وعلى من يكون مثله بالطيش يقول في القصيدة نفسها:

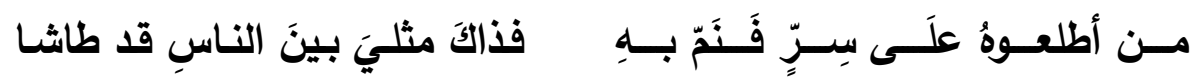

\section{الشطحات الشعريـة عند الحلاج:}

شطحات الحلاج هي أقواله التي تتاقض ظاهر الشرع، والحلاج من أشهر الصـوفية الذين عرفوا بهذه الأقوال. والثطحات أقوال صريحة تُعطي معاني الحلـول أو الاتحـاد أو الكفر والإلحـاد والخـروج على ظـاهر الـدين أو ادعـاء الألوهية أو النبوة أو غير ذلك، وأكثر ما أخذ على الحـلاج كان من شعره لا من نثره، في حين أن الشعر لا يُعد معيارًا للحكم على الالتزام بمراسم الشريعة

(شعر الحلاج بين الؤية الصوفية والحطاب الشعري.) أ.د/ أنس الفقي 
من عدمـه، ولذلك نجد أن المحكمـة التي نصبت للحسلاج لم تحتج بشطحاته الثعرية بقدر ما واجهته بمواقف فقهية أفتى بها 31، وفي هذا ما يفيد في تحديد نظرة العصر للشعر والثعراء. ومن الأبيات التي تندرج تحت هذا الباب قوله:

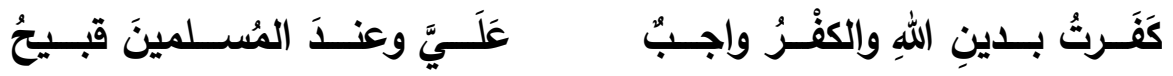
وقد حـاول كثير من الثـراح مـن الباحثين قديما وحديثا تأويـل مثل هذه الشطحات بما يتناسب مع روح الثعر الصوفي ولا يصطدم مع الثريعة، فعلى سبيل المثال، يعلّقِ الدكتور الثيبي جامع الديوان على هذا البيت بقوله: "هذا البيـت مـن شطحات الصـوفية، ولـيس معنـاه مـا يتـراءى للقـارئ العـابر ، بـلـ المقصود أن للدين شكلين: شكلًا بسيطًا يتمثل في الشرائع العمليـة المعروفة التي ترتبط بالأنبياء بوصفهر وسـائط بين الله والنـاس، وشكلًا آخر جوهريـا خالصًا لا يعرفه الناس، بل قد لا يؤمنون بـ بسهولة. والحلاج يكفر بدين الله أي يغطيه ولا يبوح به، باستعمال كلمة الكفر استعمالًا لغويَّا لا اصطلاحيَّاِ3. ويذكر لويس ماسينيون أن معظم هذه الإشـارات والتعاليم لـ يفهمها أبناء جنسـه، وإنمـا فهموا القليل منها كقولـه مثًاً "أيها النـاس: إن الله يُحَدّثُ الخلق تلطفًا فيتجلى لهم ثم يستتر عنهم تربية بهم، فلولا تجليه لكفروا جملة، ولولا ستره لفتتوا جميعًا، فلا يديم عليهج إحدى الحالتين. لكني ليس يستتر عني لحظة فأستريح، حتى استهلكت ناسونيتي في لاهوتيته، وتلاشى جسمي في أنوار ذاته فلا عين ولا أثر ، ولا وجه ولا خبر". ومن الشطحات النثرية المنسوبة إلى الحـلاج والتي تدور حول هذا المعنى قوله "من فرّق بين الكفر والإيمان فقد كفر ، ومن لم يفرّق بين الكافر والمؤمن 
فقد كفر "34 فالكفر والإيمان كلاهما مقدّر، من قبل الحق، فلا فرق في الحقيقة بينهما عند الحـلاج. أمـا الكافر والمؤمن فهما شخصسان موصوفان بالاختيار وما دام الاختيار الإنساني قد دخل في الأمر فهنا وجب التثريق بين الكافر والمؤمن على حسب ما يفهم من قوله. ومن شطحاته المشهورة قوله:

رَكبْتُ البَحْرَ وإنْكَسَرَ السففينةُ

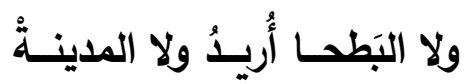

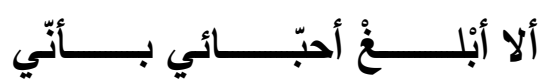
عَلَى ديـنِ الصـليبِ يكسونُ مَوْتِي وهو يشير هنا إلى أنه سيموت مصلوبًا؛ حيث إنه تعاطى أسباب الإنكار عليـه، ولكنـه قالها بأسلوب يوهم بخروجـه من الإسـلام إلى المسيحية، وكأنـه يعدد عمدًا إلى إثارة الناس عليه، في حين أنـه لا يفرق أصـلًا بين الأديان السماوية كما ورد بشعره فيقول:

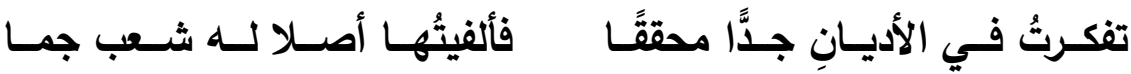

ولذلك يروى في أخبار الحلاج أن الحسين بن حمدان تبعه بعد أن قال ما سبق: (على دين الصليب ...) في سوق بغداد يقول: فتبعته، فلما دخل داره كبّر يصلى، فقرأ الفاتحة والثشعراء إلى سورة الروم وبكى، فلما سلّم قلت: يا شيخ، تكلمت في السوق بكلمة من الكفر، ثم أقمت القيامة ههنا في الصـلاة. فما قصدك؟ قال: أن تُقتل هذه الملعونـة، وأشـار إلى نفسه. فقلت وهل يجوز إغراء الناس على الباطل؟ قال "لا، ولكنّي أغريهم على الحق، لأن عندي قتل هذه من الواجبات، وهم إذا تعصبوا لدينهم يؤجرون"35. وهذا الحوار يعبر عن اعنى رؤية خاصة لدى الحلاج قد يخالفه فيها أكثر الناس.

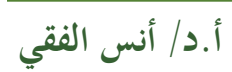

(شعر الحلاج بين الؤية الصوفية والحطاب الشعري.) 
وفي هذه الثطحة بالذات (على دين الصليب ...) أدلى لويس ماسينيون بدلوه في بيان دلالتها التي تدعم وجهة نظره، فيذكر أن الحسلاج حينما قال لخادمـه ابن فاتك متى نُنَوْرِ؟ فرد عليه، مـا تعني؟ قال يوم أصلب، قصـد حينئذ أن يوم النيروز كما أنه نهاية سنة وبداية سنة جديدة، فكذلك نيروزه هو بداية حياته الثانية، حياته الحقيقية التي يتحد فيها بالله. "لأن الحلاج إذا أخفق في تحقيق رسالته الأرضية في الانتصار على الظلم، فلابد وأن يبذل دمه على الصليب قربانـا ليكثف عن أعين البشر حجاب المـادة، ويجلو عن عقولهم الأوهام والأباطيل، إن روحه بعد صلبه ستتحرر من قيود الزمان والمكان، لقد جاء الحـلاج بفلسفته تلك سـابقًا عصـره، فلم يخدـ ع أبنـاء زمانـه وإنمـا تركهم يقارنون بينه وبين المسيح"36. ويعلّق د. شوقي ضـيف على البيتين السـابقين "ألا أبلـغ أحبائي.." بقولهـ: "وهو لا يريد أن يقول إنه انسلخ عن الإسلام وأصبح لا يريد الموت في بطحاء مكة ولا في المدينة المقدسة، إنما يريد أن يقول إنها يرى الله في المسجد وفي الدير وفي كل معبد من معابد الديانات. فالديانات جميعا عنده سواء. وفي الحق إن أقواله وأشعاره تحمل كثيرًا من الإيهام والغموض حتى لتصبح أحيانًا كما في كتابه الطواسين- ألغازًا خاصة"37. وهكذا يحاول الباحثون وغيرهم من المهتمين بالنصوص الصوفية تأويل تلك الشطحات كلٌ على حسب مشربه ورؤيته، ويبقى في النهاية المعنى الصوفي الكامن وراء هذه الشطحات حمّالا للدلالات المتعددة المرتبطة بعوامل نفسية 
واجتماعية وتاريخية؛ لتمثل بابا مفتوحا للبحث العلمي والذوق الفني على مدى العصور -

وهنـاك علاقـة وطيـدة بـين الثـطحات الحلاجيـة وبـين بعض العبـارات الغامضــة التي عمد الحـلاج فيها إلى الألغاز والتعميـة واللف، فكمـا أنـه خرج بشطحاته عن الخط الشرعي فقد خرج بتلك العبارات الغامضـة أو الملغزة عن الخط الفكري السـوي للمتلقـي الــي يريـــ أن تصـله الرسـالة الثـعرية كاملـة صافية. وقد ورد في أخبار الحلاج أنه سُئل مرة أن يشرح أبياته التي يقول في مطلعها: أنتـ أم أنا هذا في إلهين فقال: لا يسلم لأحد معناهـا إلا لرسول الله صلى الله عليه وسلم استحقاقًا ولي تبعًا

\section{المنظومات الملغزة:}

كـان للحـلاج جمهـور مـن العامـة، والعامـة تُبهر عـادة بالإلغـاز والإيهـام والتعميـة، ولذلك نجد في شـعر الحـلاج بعض التراكيب التي اتسـت بهذه السمات، بـل إن لـه مقطعـات كاملـة جـاءت ملغزة وكأنـه صـاغها في صـورة مسألة أو لغز ليحلـه النـاس. وهذا الإلغـاز جاء على أشكال متتوعـة: فهناك بعض التراكيب التي عمد الحـلاج فيهـا أن يجمـع بـين المتناقضـات ليحقق الإلغاز والتعمية والمفارقة وبالتالي الرمز إلى فكرة معينة كقوله:

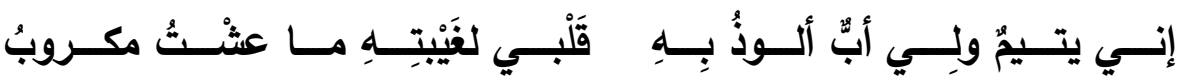

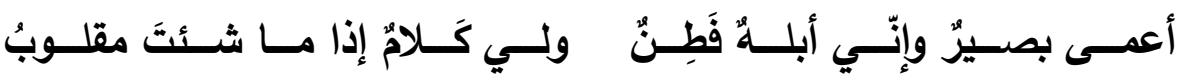
وهـو هنـا يصـرِّحُ بنفسـه بتعميـة كلامـهـ "ولـي كـلام إذا مـا شـئت مقلـوب" والشيء نفسه نجده في مثل قوله:

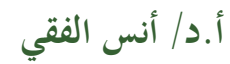
(شعر الحلاج بين الؤية الصوفية والحطاب الشعري.) 


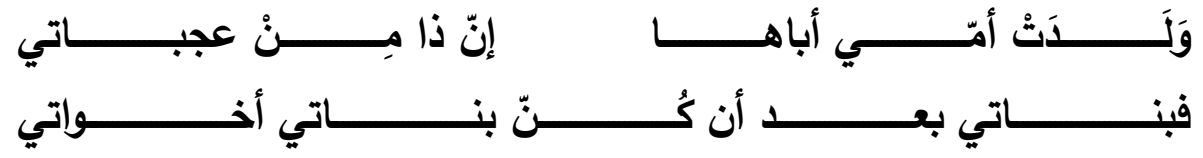

وهي قصيدة طويلة يأتي معظمها على هذا النسق من التعمية والإلغاز يقول

فيها:

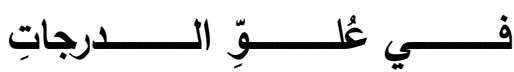

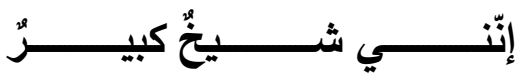

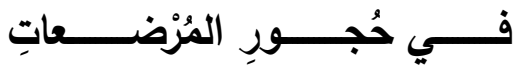

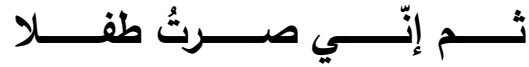

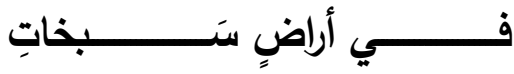

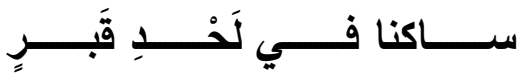

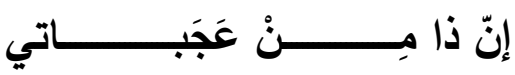

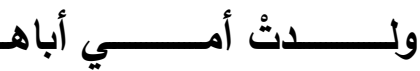

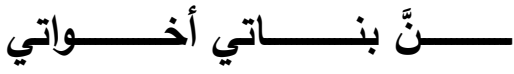

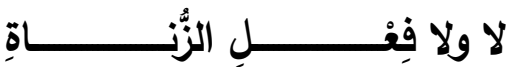

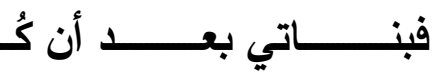

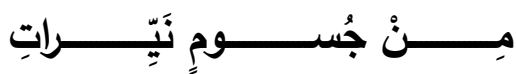

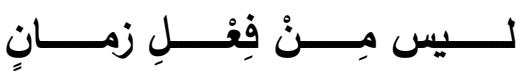

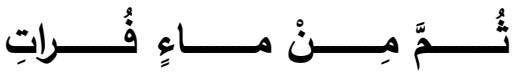

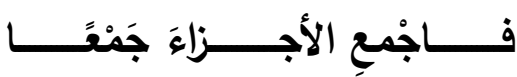

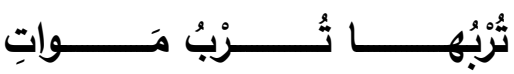

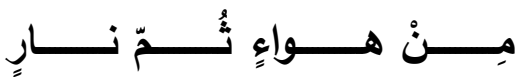

مَســـــنْ كُـــــــؤوسِ دائـــــــــراتِ

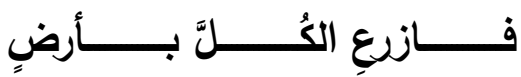

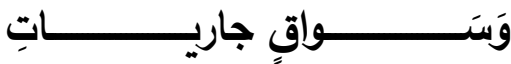
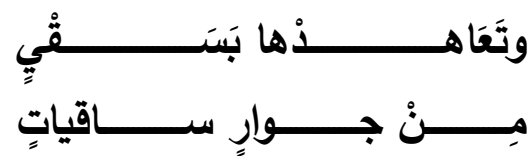

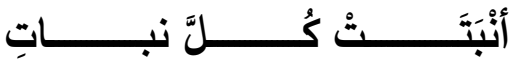

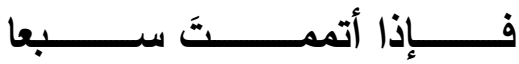

وواضح أن رموز هذا العبارات تدور في فلك النظريات الصوفية المعروفة

من وحدة الوجود ووحدة الشهود التي طالما صاغها الحلاج بأساليب متنوعة.

كما نجد سيطرة هذا الجانب النظري الملغز على حديثه عن العشق الذي

هو ألصق الجوانب الصوفية بروح الثعر وأبعدها عن النظم النظري، بيد أن

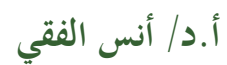

(شعر الحلاج بين الؤية الصوفية والحطاب الشعري.) 
الحـلاج يحـاول بطريقته النظريـة المعتادة أن يطرح نظريـة العشق على بساط الثعر بأسلوب ملتف معقد مصبوغ بالتكرار وبتوظيف حروف الهجاء. يقول:

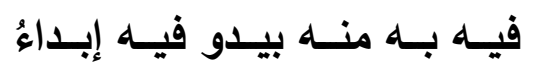

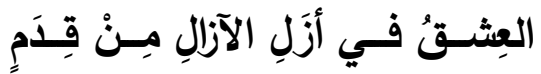

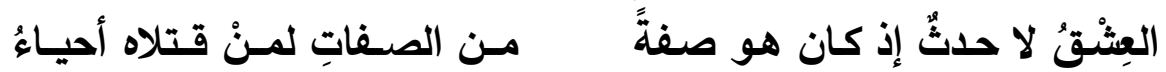

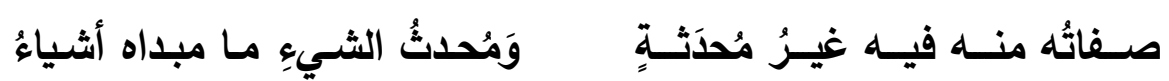

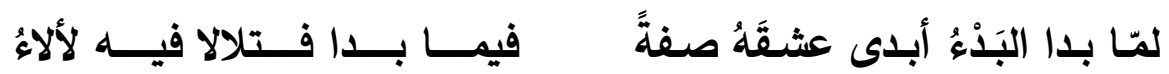

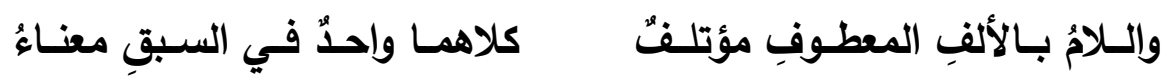

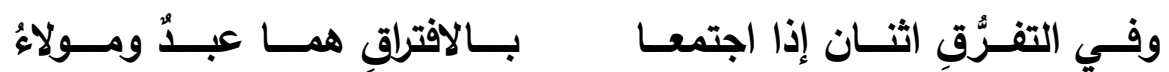

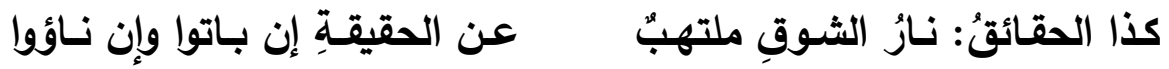

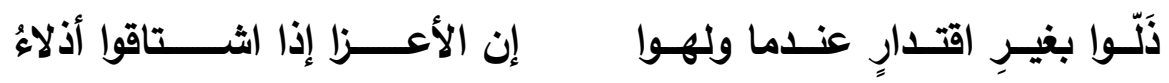
فهو يريد أن يعبر عن قدم العشق وأنه أزلي فهو العاشق والمعشوق لأنه هو الوجود جميعـ، هو كل شيء، وعلى حد تعبيره كلاهما واحد، أمسا عن التثرق بلسان الفرق، فهما المولى والعبد. وهذه النظرية هي نظرية الاتحاد التي مفادها ألا موجود في الحقيقة إلا الله الواحد.ويعرض الحلاج جانبا من تجربته الصوفية في صياغة متداخلة بتعدد الإضافات وصعوبة التقسير ثم يطلب من المخاطب أن يعي ذلك بعقله يقول:

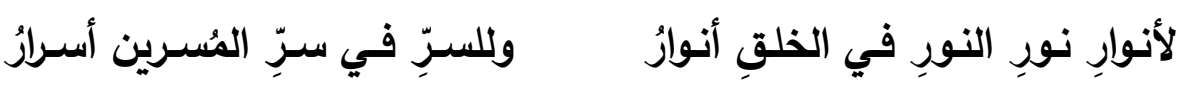

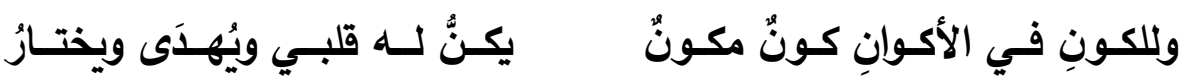

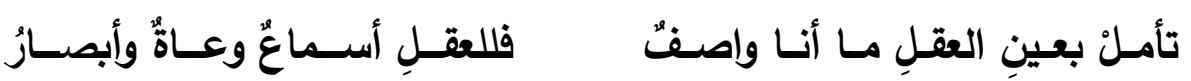


فهو هنا يذكر العقل القاصر الذي لا يستطيع فهم الإشارات الذوقية ويطلب منـه أن يتأمل، ولكن يبدو أنها لا يقصد ذلك العقل النظري المـادي بل يقصد البصيرة التي لها سمع وبصر "فللعقل أسماع وعاة وأبصار".

\section{الإلغاز باستعمال حرف الهجاء:}

وللحلاج في هذا الجانب منظومات ملغزة بطريقة أخرى، يظن من طريقة صياغتها أنه تعدد إيرادها بهذا الثكل الذي يشبه اللغز المنظوم، وهو شكل بديعي تطور فيما بعد في عصور الأدب المتأخرة واحترفه بعض الثعراء، بيد أن الحلاج لم يحترف هذا النوع من الثعر ، بل ربما يكون قد صـاغه ليظهر

$$
\text { معرفته بخبايا الحروف وأسرارها }
$$

يقول في إحدى مقطوعاته ملغزًا في كلمة "توحيد":

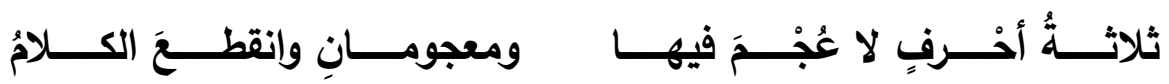

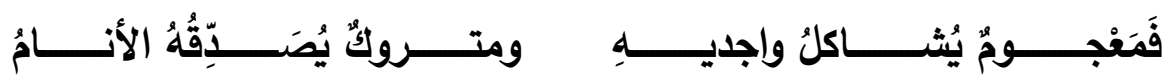

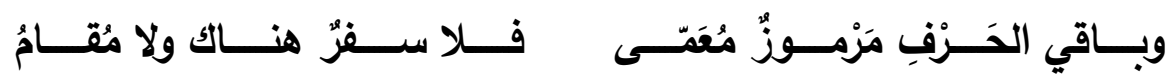
ويقول ملغزًا كلمة "اتحاد"40

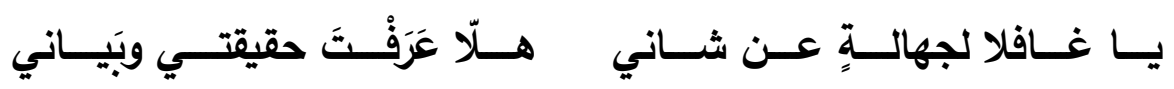

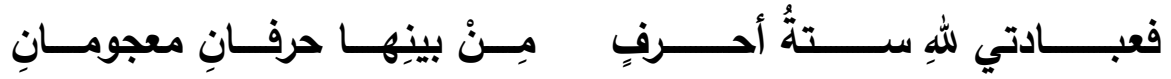

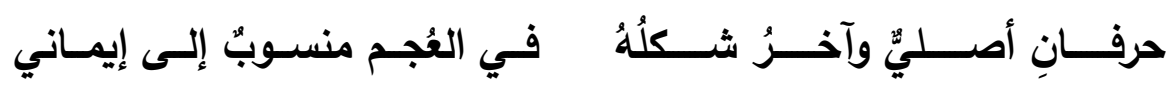

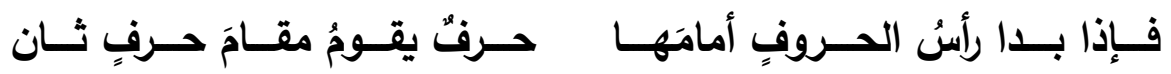

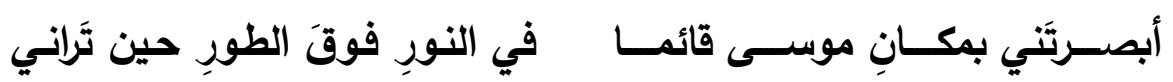




\section{القسم الثاني: المعاني الوجدانية والعثق الإلهي:}

على المستوى الوجداني يتحقق معنى الثعر، والثـعر الصوفي خاصـة لـه القددح المعلّى في هذا المجـال، والحـلاج لـه مقطعـات كثيرة صـاغها تعبيـرًا وجدانيَّا خالصًا عن حالة صوفية عاشها وأحسّها فجاءت مقطوعاته تلك رقائق تقلّب من خلالها في المعاني الغزلية المتنوعة. التوحد مع المحبوب: على رأس هذه المعاني التوحد الكامل مع المحبوب، فهذا المعنى طاغ في شعر الحلاج، نجده يلح عليه في أكثر من موقف يقول في إحدى قصائده المطولة:

لبيـكَ لبيـكَّ يـا قَصــدي ومعنــائي

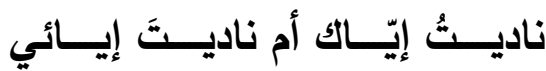
يــاجُملتي وتباعيضـــي وأجْزائسـي

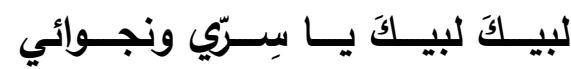

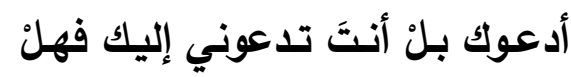

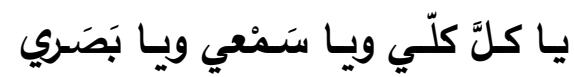

فهو حينمـا يُسلم أمـره إليـه، ويذعن بالخضـوع بين يديـه، اعترافًا بعبوديـة المحب للمحبوب يصرح بأنها من شدة توحده بـه لا يعلم مَنْ يدعو مَنٌْ لأنهما واحد، ويؤكد ذلك في البيت الذي يليه حين يخاطبه بأنـه ـأي محبوبـه- يمثل كل ذرة منه ويمثل كل شيء فيه. ويقول في موضع آخر :
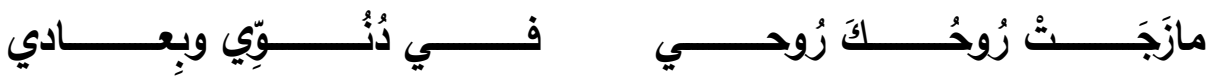

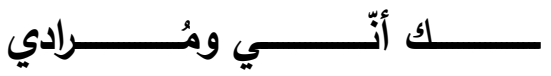

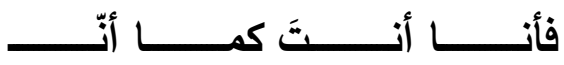

وقوله: "أنك أني" وإن لم يسر على النسق اللغوي الفصيح إلا أنه كرره في

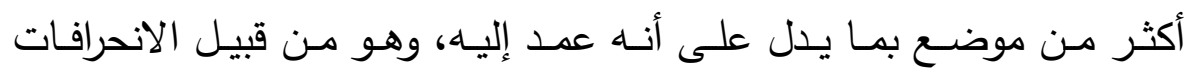
الأسلوبية التي ستعرض لها في موضعها من البحث يقول:

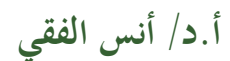

(شعر الحلاج بين الؤية الصوفية والحطاب الشعري.) 


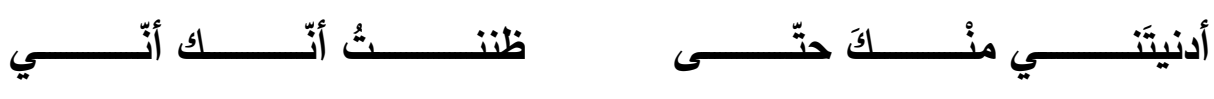

ويؤكد المعنى نفسه في موضع آخر فيقول:

لا بـسُّ ذاتـــه فمـــا ثــنَّ فــرق

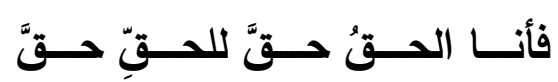

ويقول:

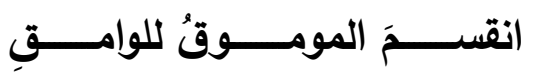

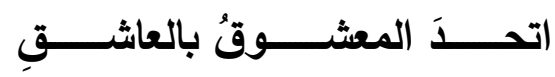

فامتحقـــا فـــي العــالم المـــاحقي

واشثــتـرك الشـــكلانِ فـــي حالـــةٍ

وليس أدل على التوحد الكامل مع المحبوب من مقطعته الثهيرة:

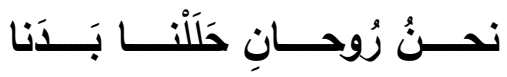

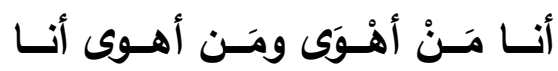

نَضْــربُ الأمثتــالَ للنــاسِ بِنَــــا

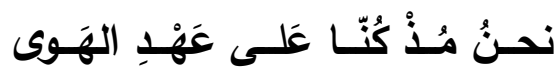

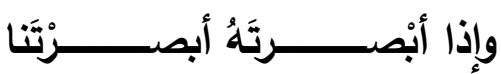

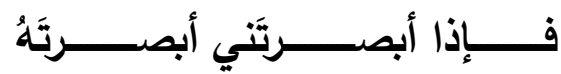

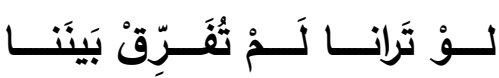

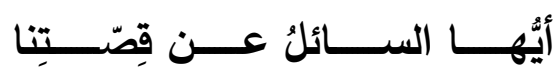

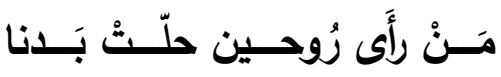

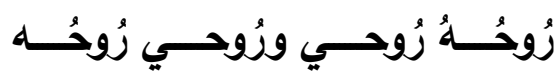

وهي مـن المقطعـات التي تناقلها النـاس عن الحـلاج وكانـت مـن أسباب

اتهامـه بالحلول والاتحساد. والثـعر الوجداني الذي يُعبّرِ بـه الثـاعر عن حالة عاطفيـة عاشها وأحسـها واستغرقته لا يجب أن يحكم من خلالهه على اعتقاد عقلي أو أن يوضع تحت حكم شرعي. فهذه الأبيات السابقة يمكن أن تتدرج تحت معاني العشق والتوحد ولا تعني بالضـرورة اعتقاده أن الله قد سكن في جسده أو حل في جسده دون سواه، بل هو تعبير عن شدة الحب الذي جمعه بمحبوبه، وأذهب عقله فغيبه عن نفسه. فاعتقاد الحلاج كما رأينا في دراستنا للجانـب النظـري مـن شعره هـو أن الله مـله الكـون، والإنسـان خليفتـه على

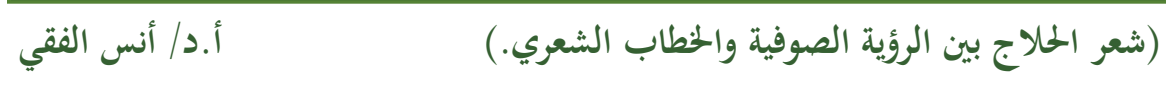


الأرض، وهو سبحانه في كلِّ ذرة من ذرات هذا الكون. فإذا وصل هذا الإنسان الذي هو خليفة الله في أرضـه إلى حالة معينة من الترقي والسمو أحس بهذا الوجود الإلهي في سـائر ذراته، بل في الكون أجمع. وهنـا ـكما قلنـا سـابقًاتضيق العبارة وتبدأ الإشارة التي يدركها قوم ويصطدم بها آخرون على حسب

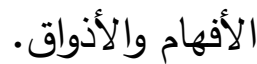
والحلاج العاشق لا يعني بهذا كله بقدر ما يُعني بالتعبير عن ذلك التوحد الذي دفعه إلى الشطح حتى في عالم الإشارة، وإلى استعارة ألفاظ من الثرع نفسه يؤكد بها اتهام الناس لله بالتطاول على الثريعة. يقول:
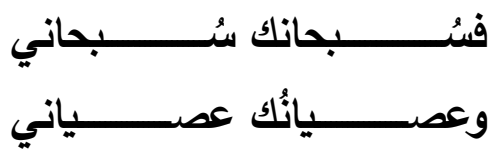

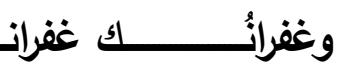
إذا قيــــلَ هـــــــو الزّانـ
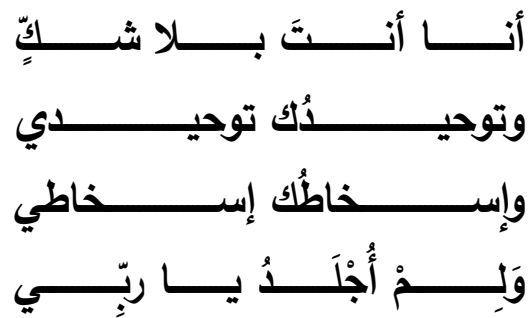

إنها حالة غير عادية، تلك التي تجعله يصرح بتأكيد التهم الموجهة إليه، ويستعير كلمات الثرع "سبحانك - سبحاني"، "توحيدك - توحيدي"، "غفرانك غفراني" ليقيم الدليل على نفسه. بل إنه يتطاول بعد ذلك ويتساءل بطريقة أهل الكلام التي تناقض التصوف أصلًا فيقول: ولم أجلد يا ربي إذا قيل هو الزاني إنها يني السؤال على ما سبق من مقدمات. إنها حيرة المحب وتغزله في محبوبه لا حيرة العقل، فالشعر لله منطقة خاص. لأنها لو كانت حيرة العقل ما عبّر الحسلاج قبلها عن هذا التوحد الكامل، فحيرة العقل تتؤدي إلى التشكك والنفور ، أما حيرة المحب فهي من قبيل التلذذ بمنازلات المحبوب بين الجمال والجلال. 


\section{المعاني الوحدانية المصاحبة للعثق:}

التعبير عن العشق يتضمن كثيرًا من المعاني، منها ما سبق ذكره، كالتوحد مع المحبوب، وقد أفردناه لأهميته في دعم الجانب النظري لشعر الحلاج. أما المعاني الأخرى فتتمثل في شكوى المحب، ووصف حال العاشق الذي تفانى في حـب معشـوقة، والتغـزل في جمـال المحبـوب، وخلـع الغـذاء، واسـتجداء الوصال من الحبيب واستعطافه ليرقَ لحال هذا العاشق، وكذلك التلذذ بالنظر إلى المحبوب ومخاطبته، والاستماع أيضًا إلى خطابه، مع بيان هذه الكيفية التي تتم من خلالها عملية التخاطب.

شكوى المحب: الثكوى عند الحلاج هي شكوى المحبين العاشقين، التي عادة ما تتعلق أسبابها بشقين: شق يخص المحب، وشق يخص المحبوب. أما الثق الذي يخص المحب العاشق فهو شدة الحب والتعلق والوجد بمحبوبهـ إلى

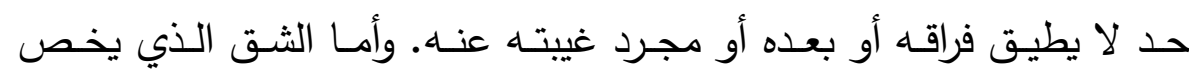
المحبوب فهو ذلك الفراق أو البعد أو مجرد الغيبة عن المحب دلالًا أو تكبرًا أو ترفعًا أو امتحانًا له أو غير ذلك من الأسباب. وهناك سبب رئيسي للشكوى عند الحلاج متعلق بمعنى التوحد مع المحبوب، هذا السبب هو الثعور أحيانا بوجوده كإنسان ووجود الله كرب معبود، أي الثعور بوجود اثنين لا واحد. فهذا بالنسبة للحلاج من أهم أسباب الثكوى. فهو لا يريد هذا الثعور إنما يطمع دائما في التوحد يقول: - n

فارفع بلطفك إنبِّي من البين

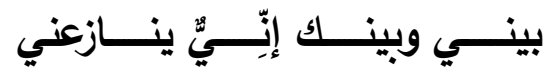


فهو يشكو من تلك الإنيّة التي تسبب الاثنينية، لذلك يطلب أن يرفعها الله سبحانه ليكون هو هو، أي ليجمعه جمعًا مطلقًا فلا يعود إلى إنيته مرة أخرى، ولن يكون هذا الأمر إلا برضا المحبوب. يقول:
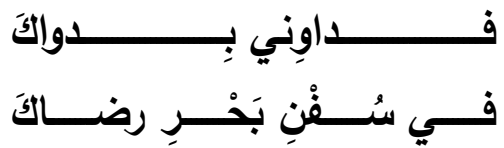

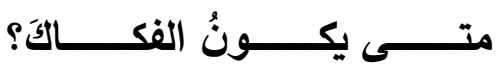

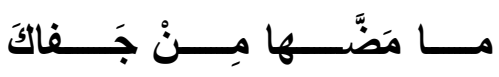

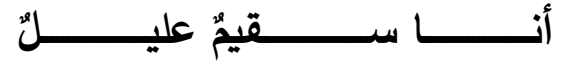
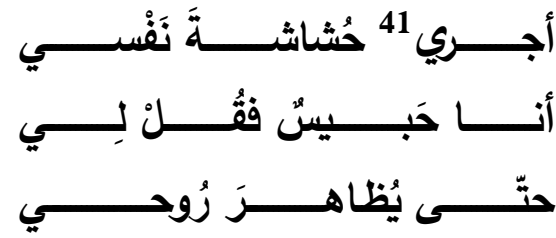

والحبس الذي قصده الحلاج هنا هو حبس روحه في قفص جسده، وحينما تصـعد الروح إلى محبوبها ليجمعها بـه تتحقق لـه السعادة العظمى والراحـة الكبرى التي يطهـح إليها. ولكن الجهـع التام لن يكون إلا بالموت الحقيقي، الموت الذي يعرفه الجميع، أما حالة الجمع التي ترد عليه أحيانًا ثم يعود بعدها إلى حالـة الفـرق والاثنينيـة، أي إلى كونـه إنسـانًا يعـالج كربـات الحياة الـنيا وخداعها، فهي لا تشفي لوعته ولا تسد رمقه لذا فهو يشكو حُكْمَ الهوى:

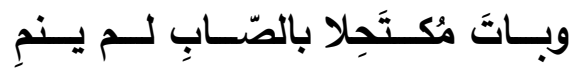

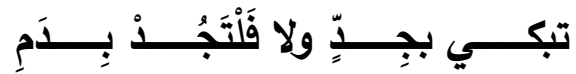

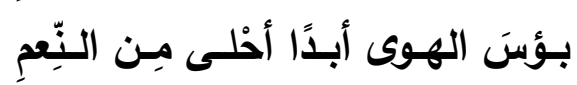

قضَسى عليـه الههوى ألا يذوقَ كريًَ يقـولُ للعينِ جُودي بالـدموعِ فِإنْ

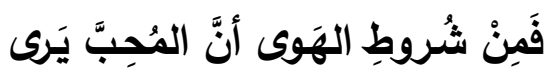

إن الهوى قد حكم عليه ألا ينام، وأن يبكي بكاء حارًا بالدمع أو بالدم، يبكي شوقًا وينفطر عند التنائي؛ لأنه يعيش في صراع حاد بين الفرق والجمع، وفي الوقت ذاته لا يستطيع أن يتعجل الموت الحقيقي؛ لأن محبوبه هو الذي قدر موعده، فمـن اسـتعجل موعده فقد أسـاء الأدب مـع المحبـوب، فليس لـه إلا 
السكون تحت مجـاري الأقدار، بـل إن الأمـر أكبر مـن ذلك، فشروط الهوى تقضي بأن يرى المحب هذا البؤس أحلى من النعم، وأن يستعذب هذا العذاب. وللحلاج قصيدة طويلة ${ }^{42}$ كتبها على هيئة خطاب شعري يشكو فيه حاله، ويصف لوعته يقول:

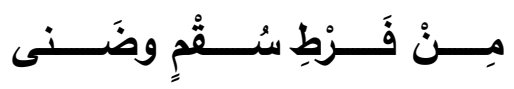

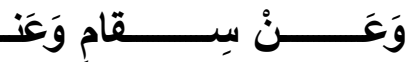
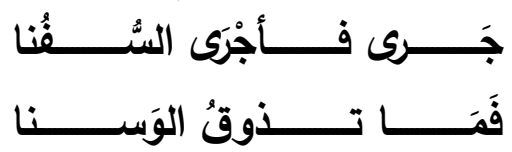

فَنَــــــا الفَنْ

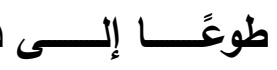

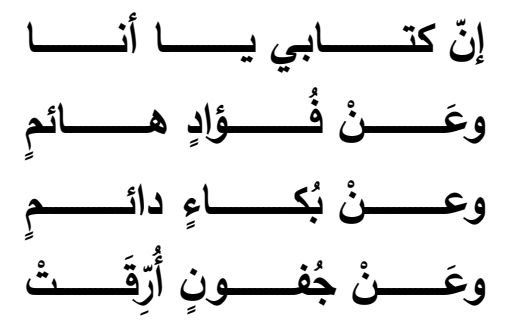

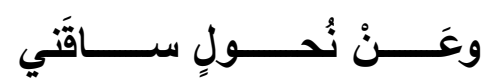

وهكذا يمضي في القصيدة شاكيا متألما من البعاد والجفا. ولا يفوتتا هنا أن نلحظ أن هذه المعاني الوجدانية ترتبط بعوامل متعددة كالحالة التي يعيشها، والمرحلة العمريـة التي يمر بها، والمقام الصـوفي الذي وصل إليهـ كمـا أثرنا سابقًا.

إذن فخلاصـة شكوى الحـلاج هي من حالة البعد أو الفرق التي تتتابه من حين لآخر طالما يعيش في قفص الجسد، هذا الحجاب الذي يقف حائلا دون الجمـع المطلق بمحبوبـه، وهذا الجمـع هو الذي يعبر عنـه بالعودة إلى وطنـه يقول:

طوعًا ويُسـعلني بـالنَّْْحِ أعدائي أبنْي عَلى شَجَني مِن فُرَتِي وَطني

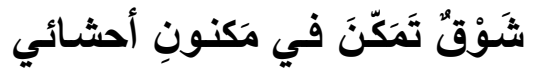

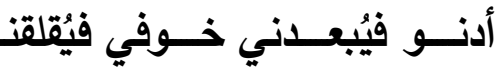
مَولاي قد ملَّ مِنْ سُقْهي أطبّائي

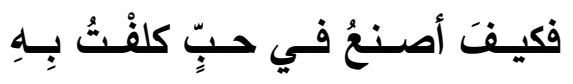


فلا سبيل إلى الثفاء منه إلا به هو، فهو الداء والدواء، وما دام الأمر كذلك فلتظل الثكوى قائمة، والبكاء دائمَا، واللوعة مستمرة، حتى يجمـع بالموت على لهى حبييه:

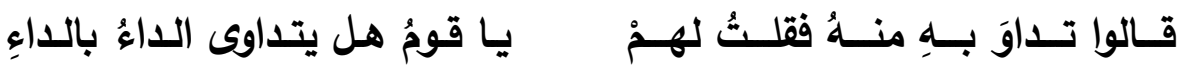

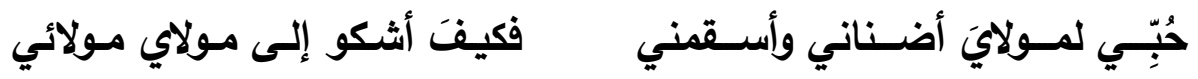

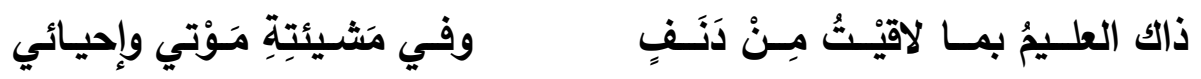

\section{التغزل في جمال المحبوب:}

لا نجد في شعر الحلاج كثيرًا من المقطعات التي تتضمن التغزل المباشر في جمال المحبوب، وقد يرجع السبب في ذلك إلى بكارة التجربـة الثـعرية الصوفية؛ حيث يعد الحلاج واحدًا من روادها الأوائل الذين حرصوا على غرس النظرية الصوفية في فكر الناس أولا. ومع ذلك فإننا نجد من شعره ما يتناول هذا الجانب.

ومن المقطعات التي تغزّل من خلالها في جمال المحبوب مقطعته التي

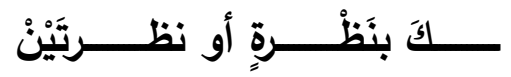

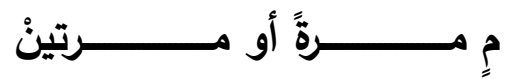

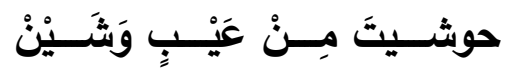

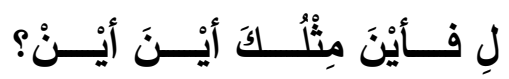
فاسـتنارَتْ فمـا لها مِنْ غروبِ يقول فيها:

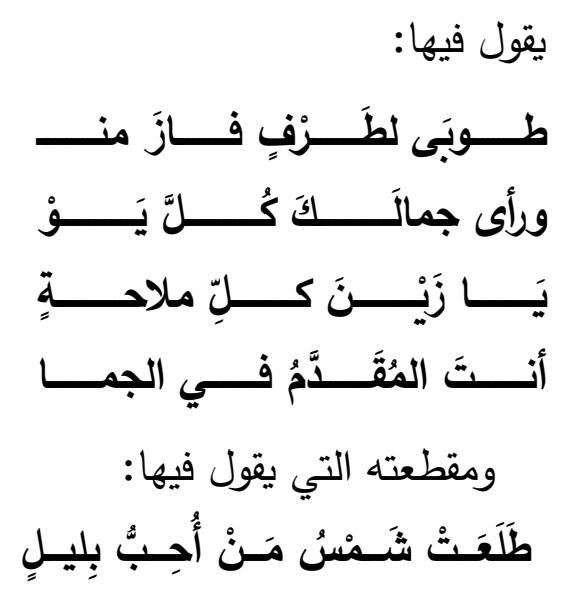

ومقطعته التي يقول فيها:

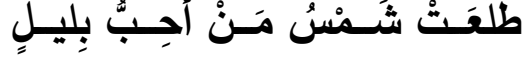


ويصف الحـلاج حال العاشقين جميعًا فيقسم أنهم موتى من الحب ويؤكد على صدقهم فيقول:

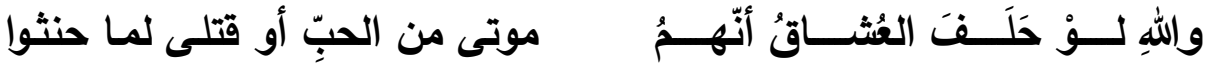

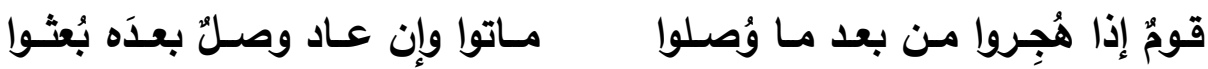

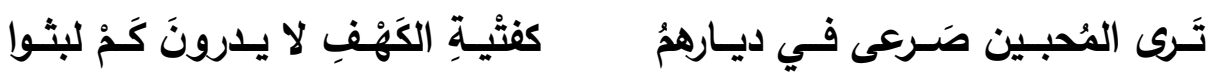

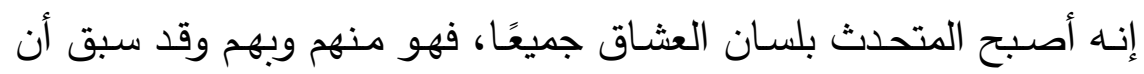
أشرنا في حديثنا عن الجانب النظري أنه كان يحترم الصحبة أو الأخوة في الطريق، وكثيرًا ما تحدث عن العشاق وأنهم روح واحدة، فهو عندما يتحدث عنهم إنما يتحدث عن نفسه.

أما عملية التخاطب التي تتم بينه وبين حبيبه فقد عبر عنها بقوله:

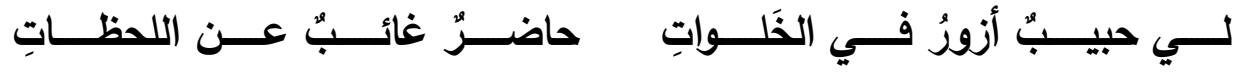

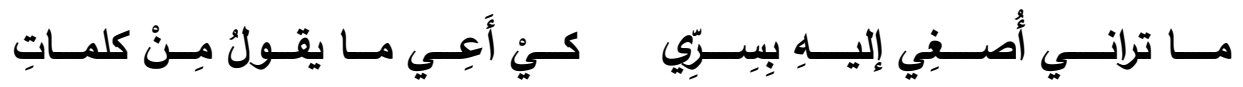

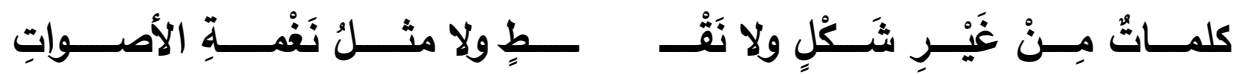

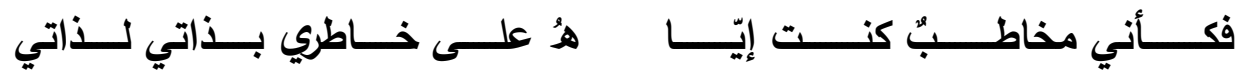
إنه خطاب أشبه ما يكون بالوحي من المحبوب الأعظم إلى حبيبه، وهي كلمات ليست مكتوبة ولا مسموعة كالأصوات الدنيوية، بل إن الإصغاء لها لا يكون بالآذان إنما يكون بالسرِّ الذي صفت سريرته. ويوضـح ذلك في مقطعة

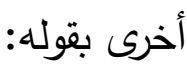

فــــانَ عِلْمـــــي عَاَــــى لِســــاني خـــاطَبْني الحـــقَّ مِسـنْ جَنــــاني

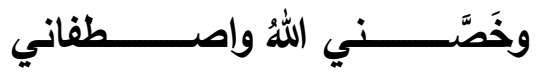

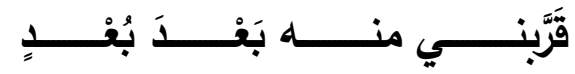


إذن فلسانه ترجمان المحبوب، إنه الواسطة بين اللاهوت والناسوت إن جاز التعبير • ثم يبيّن الحـلاج في مقطعـة أخرى هذه القضـية -قضـية التخاطبــ ولكـن على مجـال أسـى وأقـرب إلى فكـر النـاس الــين يؤمنـون بالأنبيـاء ويعتقدونهم واسطة بين الخلق والحق فيقول:

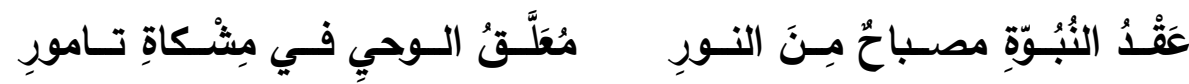

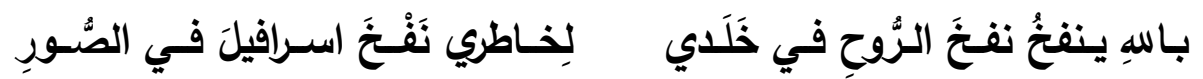

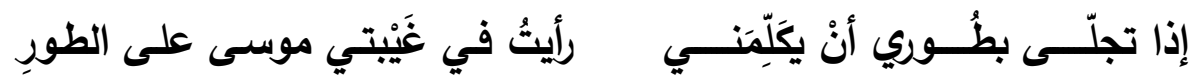
لقد اختصر الكون كله في ذات الإنسان، فالتامور : يطلق على القلب أو دم القلب أو صـومعة الراهب أو الناموس 43 أي أنه باختصـار هو القلب المقدس الذي تطهر من رغبات الدنيا، وأصبح أهلا لتجلي الحق فيه. وفي هذا القلب المقدس تكمن النبوة والوحي، وفي الإنسان تكون نفخة الصور التي بها تبعث الأجسام والأرواح، وفي القلب الذي هو ـالطور - يتجلى الحق فيغيب الإنسان عن وجوده حتى يفنى في الحق ليستطيع أن يتلقى عنه الوحي والكلام كما تلقاه موسى عليه السـلام على جبل الطور • وكلمات الوحي التي يتلقاها هي تلك التي وضعها الحلاج قبل ذلك: سط ولا مثل نفمة الأصوات كلمات من غير شكل ولا نَقْــــ ومن خلال استعراضنا للمعاني الوجدانية عند الحلاج نلاحظ أنه لم يستدع ويوظف تلك المعاني بصورة كاملة، حيث نرى أن رؤيته النظريـة تصاحبه في معظم قصائده الوجدانية، فهي تلحُّ عليه دائمًا، ولعل هذا ما دفعه إلى أن يقول في مطلع ديوانه: 


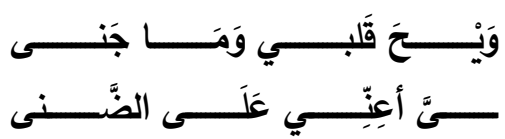

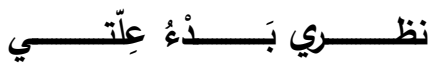

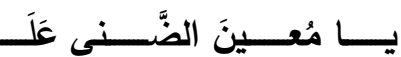

\section{القسم الثالث: الخصائص الأسلوبية العامة لشعر الحلاج أولاً: المستوى الصوتي: \\ الشكل العام لشعر الحلاج}

جاء شعر الحلاج متتوعًا بين قصائد ومقطعات صغيرة وأبيات مغردة، فعلى حسب ما تحقق من شعره الذي تأكدت نسبته إليه بالديوان 44 نجد أن مجموع مقطعاتـه تسـحُ وثمانون، منها قصيدتان طويلتـان نسبيًّا تبلـغ الأولى 20 بيتًا، والثانية 19 بيتًا 45، وله بعد ذلك تسعُ قصائد عدد أبيات كل منها يتراوح ما بين 13 و 7 أبيات، وبقية شعره بعد ذلك مقطعات صغيرة، يغلبُ عليها الثنائيات والثثلاثيات. فله 27 مقطعـة ثنائية (من بيتين)، ولـه 21 مقطعة ثلاثية، و12 مقطعة رباعية، و 9 مقطعات خماسية، و 5 مقطعات سداسية، وأربع مقطعات

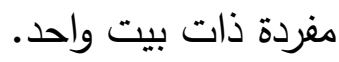

وبالنسبة لمختاراته العروضية، فقد كان مفضـلا لبحر البسيط؛ حيث بلغت مقطعاتـه فيـه (22) مقطعـة، بالإضـافة إلى (9) مقطعـات كتبها على مخلـع البسيط، يليـه الطويل (16) مقطعة، ثم الرمل (10)، فالخفيف (7)، فالوافر والسريع لكل منهما (6) مقطعات، ثم بقية الأبحر التي استخدمها وهي المجتث (4) والكامل (3) والهزج (2) والمتقارب (2) والمنسرح (1) والرجز (1). أما أكثر قوافيه استعمالا فكانت قافيتي الراء والنون، اللتين تجاوز ما كتبه في كل واحدة منهما ستين بيتا، يليهما الألف والتاء اللتان تجاوز ما كتبه في

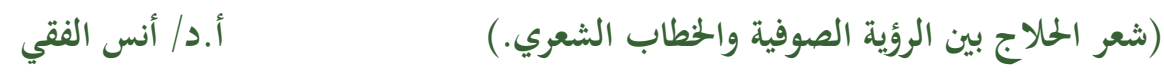


كل منها (40) بيتًا، ثم قافية الباء بحوالي (30) بيتًا، ثم الميم بحوالي (21) بيتًا، ثم بقية القوافي الأخرى بنسب أقل كثيرا مما ذكر ، أي أقل من (20) بيتًا. ومن الجوانب الموسيقية في شعر الحلاج سيطرة القوافي المطلقة المردفة لدرجة شبه كاملة، فَجُلُّ مقطعاته تنتهي بقافية مطلقة موصولة الصوت، فهي إمـا فتحسة موصـولة بـألف، أو كسرة موصـولة بياء، أو ضــة موصسولة بـواو. وتكون أيضًا مردفة، والردف كما يقول التبريزي "ألف أو واو أو ياء سواكن قبل حرف الروي"46 ـ ولعل ذلك راجع إلى طبيعة الشعر الصوفي الذي يحتاج إلى مثل هذه القوافي التي تتاسب الإنشاد والغناء كما أن قوافيه من النوع المتواتر 47 في الثعر العربي، وهو أكثر وقوعا في الثعر العربي بسبب تتاسبه الموسيقا. والذي نخرج به من هذا الإحصاء على فرض صحة نسبة الشعر إليه بهذا الكم الوارد، هو إيثاره المقطعات الصغيرة التي لعله قالها ضمن كلام، أو في مناسبات معينة كما ورد في أخباره، وكما نقلنا عنه في أكثر من موضع. كما نستطيع أن نخرج أيضـا من هذا الإحصـاء بأن الحسلاج لم يكن يعدد إلى أن يُقصِّد القصائد أو يتممها أو أن يعرضها على أحد، بل كانت أشبه ما تكون بإشارات عارضـة أو حكم قصيرة أو دفقات شعورية على حسب الموقف الارتجالي الذي يقابله. كمـا نلاحظ أن كثرة الثنائيات عنده ربمـا يكون ناتجًا مـن تأثره بالثـعر الفارسي (المثنوي) أو الدوبيت وإن لم يجر على وزنه بل على الأوزان العربية، فيكون ذلك بدايـة تأثر ظـاهري بالثـكل والـوزن والمعنى، وقد يكون اختيـار الحلاج لهذه المقطعات الصغيرة كي تتاسب السماع الصوفي أو الإنشاد الذي 
بدأ ينتشر في عصره مع انتشار الصوفية، بل وتُقردُ لـه فصول في مؤلفاتهم يتكلمون فيها عن حكمه الشرعي ومتى يكون محمودًا أو مذمومًا ومن أبرز الظواهر الصوتية التي تواجهنا في شعر الحلاج ظاهرة التكرار، ومن المعروف أن "التكرار الصوتي في الشعر يخضـع لقوانين تختلف إلى حد ما عن تلك التي يخضع لها الكلام غير الفني، فإذا كان الكلام العادي ينظر إليه باعتباره كلامًا غير منتظم، بمعنى أنها لا يؤخذ في الحسبان تميز بنائه بوضع لغوي خاص، فإن اللغة الثعرية تتجلى كلغة قد رتبت على نحو خاص، بما في ذلك المستوى الصوتي" بوصن. وهناك خصوصية في ارتباط ظاهرة التكرار بالتجربة الصوفية وتأثيرها على

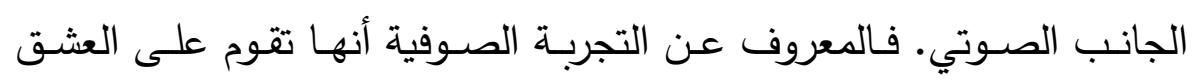
والشوق والتوحد وأحيانًا التحير • وكل هذه المعاني تستدعي أنماطًا من التكرار. فالعشق والثـوق يستدعيان ترداد الحبيب، وفي هذا تكرار، والتوحد يتطلب التكرار وتبادل المواقع (أنا أنت وأنت أنـا) والتحير يستدعي تكرار التساؤلات بصيغتها أو بصيغ مختلفة. كل هذه الأنماط وغيرها من "التكرار" نجدها في شـعر الحـلاج ظـاهرة صـوتية لافتة وقد يصـل حد التكرار عند الحلاج إلى استغراق قوافي قصيدة كاملة كما في قصيدته التي مطلعها:

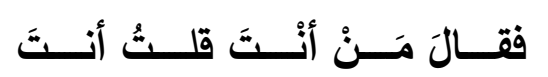
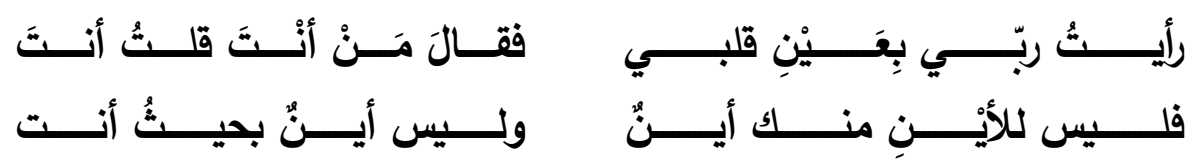
وهكذا يمضـي إلى البيت العاشر ـالبيت الأخير - مكررًا كلمـة "أنت" في آخر كل بيت مع أنه عيب معروف من عيوب القافية وهو الإيطاء.

(شعر الحلاج بين الؤية الصوفية والحطاب الشعري.) أنس الفقي 
وقد يكرر الحلاج شطرًا كاملًا في أكثر من مقطعة بنصـه تمامًا كما في الثطر الذي يقول فيه: "روحه روحي وروحي روحه"، فقد ورد مرة صدرًا للعجز

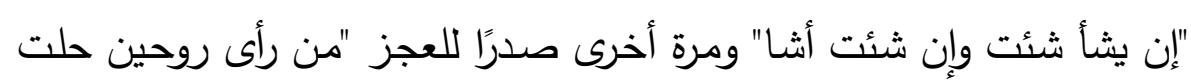
بدنا" في مقطعتين مختلفتين، بل قد يتجاوز الأمر شطر البيت إلى جملة أخرى من الشطر الثاني ويتكرر ذلك في قافيتين مختلفين كقوله:

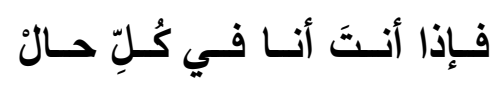

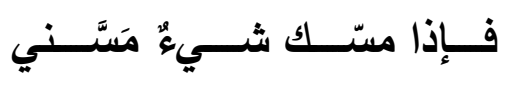
وقوله:

فــــإذا أنـــــَ أنـــــا لا نفتـــرق

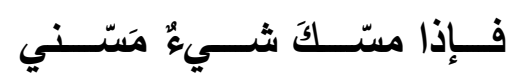
فيكاد يكون قد كرر البيت كله عدا الكلمتين الأخيرتين. وكما أنه يكرر الجمل الكبيرة فإنه يكرر المفردات أو المصاحبات اللفظية اليسيرة، كترديده لكلمات: "أنّك أنّي"، "أنا أنت"، "أنت أنا"، "لبيك لبيك"، وتكرار النـداء "يـا كـل كلي"، "يـا سـمعي"، "يـا بصـري"، "يـا جملــة الكلـل، "يـا منيـة المتمنى". ويأتي التكرار أحيانًا مصاحبًا بالتقسيم الصوتي والموسيقي كقوله:
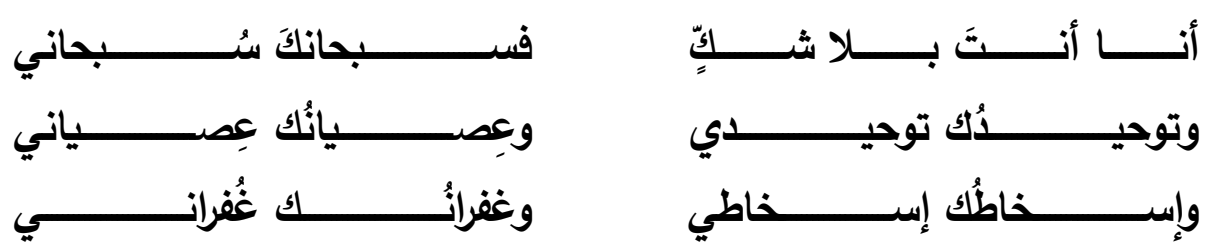

وقد يأتي التكرار مبالغًا فيه لكي يعبر عن مدى حيرته فيقول:

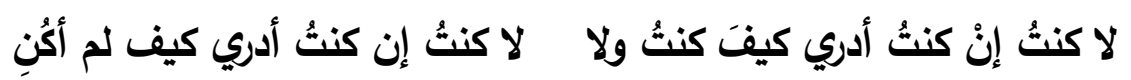
وهكذا مثل التكرار في شعر الحلاج ظاهرة واضحة أدت وظيفتها الصوتية والدلالية في الوقت نفسه. ويرى بعض الباحثين أن تكرار الأصوات والكلمات

(شع الحلاج بين الؤية الصوفية والحطاب الشعري.) أنس الفقي

\section{4}


والتراكيب ليس ضـروريَّا لتؤوي الجمـل وظيفتها المعنويـة والتداوليـة، ويعدونـه

$$
\text { شرط كمال، أو لعبًا لغويا }
$$

وهنـاك ظـاهرة صـوتية أخرى نراهـا بـارزة في شسعر الحـلاج، وهي ظـاهرة

التصريع. والتصريع نوع من الدعم الموسيقي والتهيئة الصوتية لقافية القصيدة التي ستتوالى بعد ذلك، وقد درج الثعراء العرب على تصـريع البيت الأول (المطلع) من قصائدهم ولذلك كان الغالب في القصائد العربية أن يأتي البيت الأول فيها مصرعا، ولكن ذلك ليس ملزما للثاعر، فالفرزدق ــثلا - وهو من فحول شعراء العصر الأموي بدأ قصيدته الثهيرة:

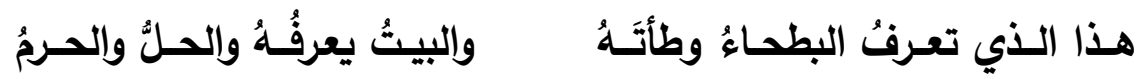
غير مصـرعة، وهناك أمثلة أخرى كثيرة في الثـعر العربي تؤيد هذا الذي وطي

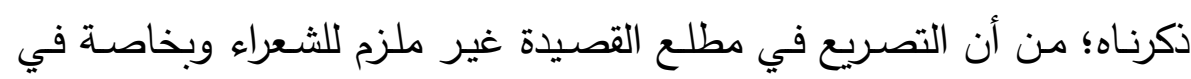
المقطعات الصغيرة. فالغالب فيها عدم التصريع. أما الحلاج: فنجده مولعا بالتصريع سواء في بداية قصائده الطويلة أو في مقطعاته الصغيرة، فمطالع قصـائده المطولة كلها تقريبا مصرعة، أما مقطعاته فيغلب على مطالعها التصريع وإن كانت ثنائية (من بيتين) أو ثلاثية (ثلاثة أبيات) فمن أمثلة تصريعه في مطلع مطولة له: لبيك لبيك يـا قصـدي ومعنـائي لبيـك لبيكك يـا سـري ونجـوائي والتصـريع هنـا يصـحبة جانبـان صـوتيان يدعمانـه، وهمـا التكرار والتوازن الصوتي فالتكرار في لفظة لبيك متوازن في البيتين، وحرف النداء مع الكلمتين 
المتتاليين لله متوازن أيضًا بما يدل على طغيان الجانب الموسيقي. ومن أمثلة التصريع في مطالع مقطعاته الثهيرة قوله: عجبت منك ومنّي يا منية المتمني وقوله:

نحن روحان حللنا بدنا

وظني فيك تهويس
أنا من أهوى ومن أهوى أنا

وقوله:

جحودي لك تقديس

ومن أمثلة ذلك مطالع في ثلاثياته:

تُكاشفُني حتى كأنّاك في نَفْسي

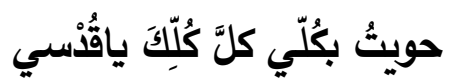

بل إنه قد يكرر الكلمة ليستغرق البيتين تصريعا كما في قوله:

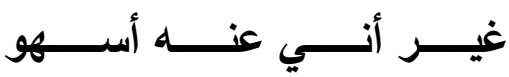

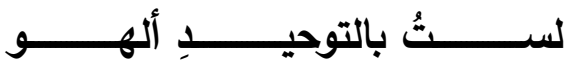

هــــــــ

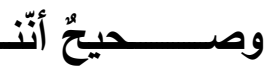

فقد كرر كلمة "ألهو" في الثطرين الأوليين ليحقق التصريع في هذه

المقطعة الثنائية.

وقد يستغرق التصـريع في القصـائد المطولـة أكثر من المطلـع بـل إنـه قد يصل إلى خمسة أبيات متوالية كما قي قوله:

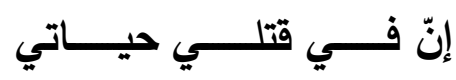

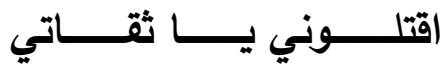

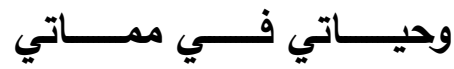

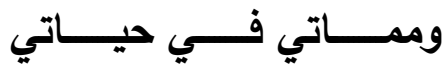

مِـــنْ أَجَـــلِّ المَكْرُمــــــاتِ

أنــــا عنــدي محــوُ ذاتــي

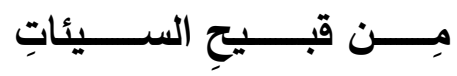

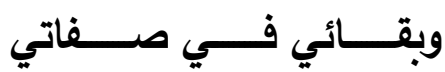

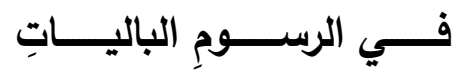

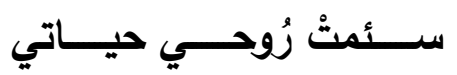

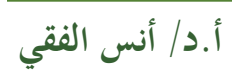

(شعر الحلاج بين الؤية الصوفية والخطاب الشعري.) 
وفي المقطعات القصيرة أيضًا قد يتجاوز التصريع البيت الأول إلى البيت الثاني وإن كان كانت القافية من القوافي الصعبة كقافية الثين مثلًا فيقول:

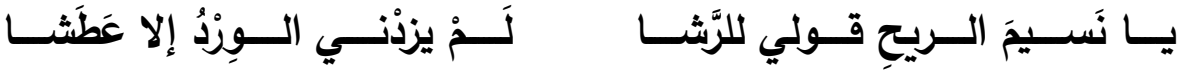

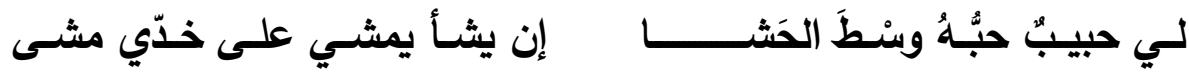
وهناك نوع من التصريع يمكن أن تطلق عليه التصريع الختامي وهو أن يصرع خاتمـة المقطعة لا مطلعها. وقد جاء ذلك في مقطعته التي يقول في بدايتها:

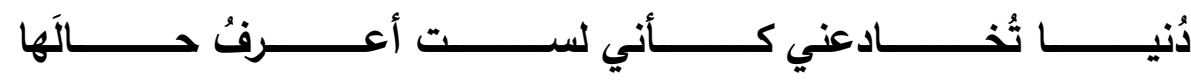
ويختمها مصرعًا بقوله:

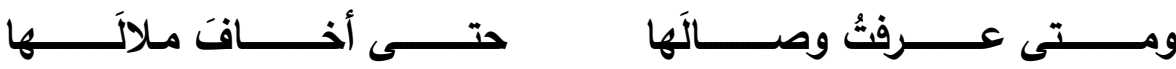
وقد يكون هذا الولع بالتصريع من جانب الحلاج مرتبطا بالإنشاد الصوتي للثـعر الصـوفي، ليحقق بهذا التصـريع المتـوع براعـة الاسـتهلال الموسـيقي وأحيانًا حسن الختام.

\section{المعحم الشعري:}

استعمل الحلاج المصطلحات الصوفية الدائرة في عصره كالسكر والصحو والفرق والجمـع والوجد والفقر وغيرهـا، ولـه قصيدة حشــ فيهـا كمّا مـن هذهـ المصـلحات معطوفـة بـالحرف "ثم"، وهـي القصيدة السينية التي يقول في مطلعها:

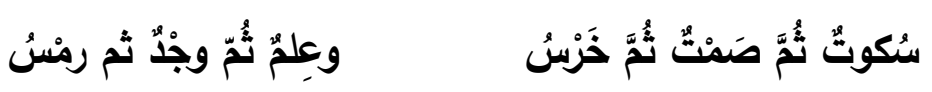
ومنها:

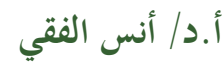

(شعر الحلاج بين الرؤية الصوفية والخطاب الشعري.) 


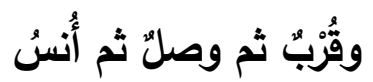

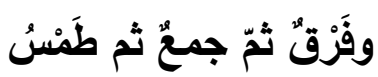

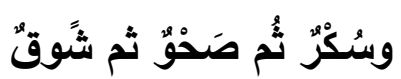

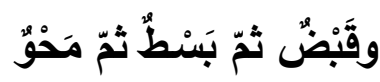

أما في غير هذه القصيدة فقد وظف المصطلحات الصوفية توظيفًا طبيعيَّا. وللحسلاج اصـطلاحات خاصـة صـاغها على سبيل الحكايـة، وقد يكون هذا المصطلح مكونًا من حرف متصل بضمير ككلمة "إني" أو "أني" فيسوقها في شعره على الحكاية بصورة "اسمية" يمكن أن ينونها كما في قوله: فــارفع بلطفــك "إنّيّـي" مــن البـين

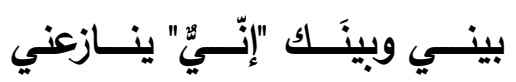
وغير منونة كما في قوله:

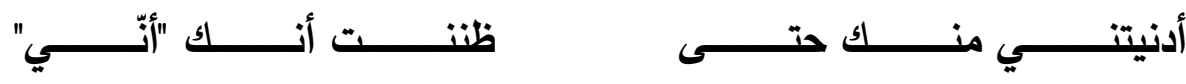
ومن اصطلاحاته الخاصة لفظة "هوية" و "لائية" يقول:

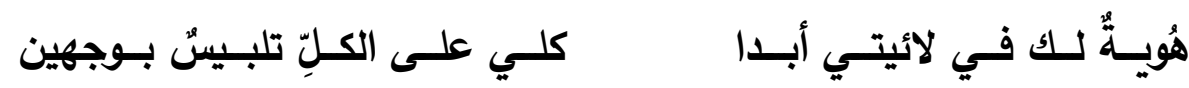
كما أنه تخصص من بين شعراء الصوفية باستعمال مصطلحيه المشهورين اللذين استعارهما من المصطلحات المسيحية: الناسوت واللاهوت، على نحو ما ذكرنا آنفًا.

كما استعمل بعض الحروف المقطعة وقد أشرنا إلى ذلك عند حديثنا عن منظوماتـه الملغزة، ولعلـه قصــ بـلك إدخـال شـعره في إطـار" المقدس" الذي

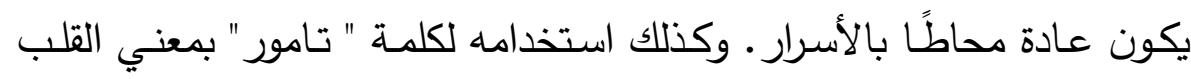
المقدس.

كما استخدم المصطلحات الإسلامية العامة: سبحان - غفران - كفر - دين - خطايـا ـ الله - الحقّ. ولفظ "الحقق" عنده متكرر في الدلالـة على الذات 
الإلهية أكثر من كلمة "الله" ولعل في ذلك إثـارة للمعتقد الصوفي السائد أن لا موجود في الحقيقة إلا الله، فهو الحق يقول:

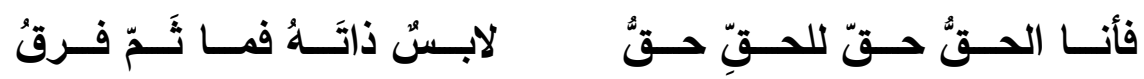
ويقول:

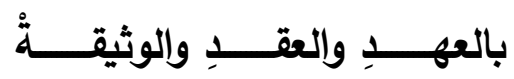

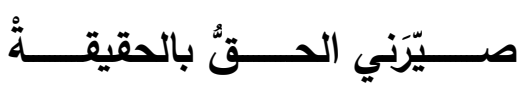
وأيضًا: خاطبني الحق، بياني بيان الحق

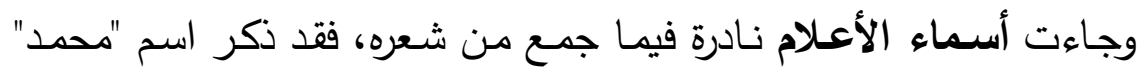
بطريقة مباشرة في تلك المقطعة الوحيدة التي عنونها المحقق بـ"مزاح الحلاج" وهي لا تتسجم مع جملة شعره، ولا نرى أنها لله؛ حيث إنها في الغزل بالمذكر ولم يذكر في أخبار الحـلاج مـا يفيد بأن له شعرًا في غير التصوف كما أن سياقها الهزلي لا يوافق أسلوب الحلاج في أيّ من مقطعاته. يقول فيها:

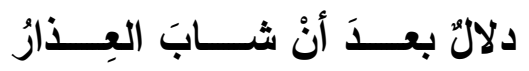

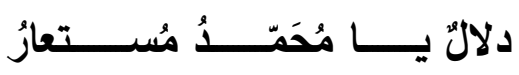

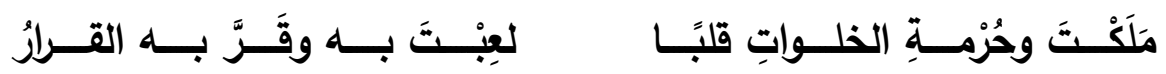

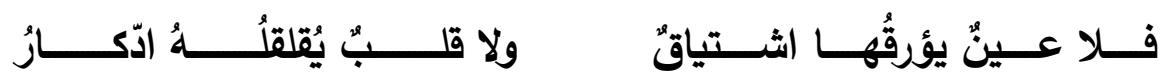

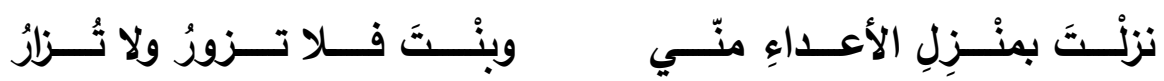
كمـا ذَهَبَ الحِمـارُ بـأمِ عمــرِو والمقطوعة قد تكون مزاحا على غير عادة الشاعر ، يُرجّحُح ذلك ما ضمّنها بـه الثـاعر في البيت الأخير، بالإضـافة إلى مضمونها شبه الهزلي المباين لمعاني شعر الحلاج. أما الأعلام الأخرى التي وردت في شعره وقام بتوظيفها فنيَّا فمنها "موسى لـى

$$
\text { والطور" وقد وردت في قوله: }
$$

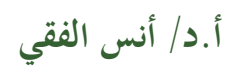

(شعر الحلاج بين الؤية الصوفية والحطاب الشعري.) 


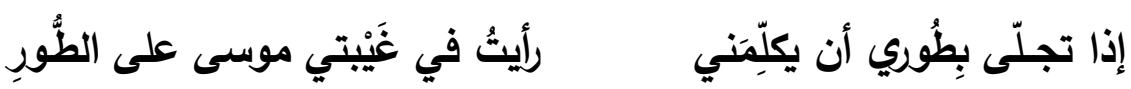

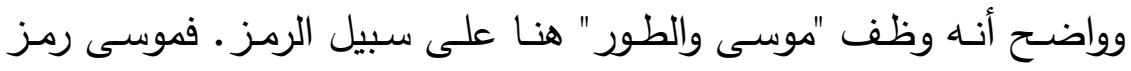
للإنسان الكامل حال التجلى، والطور رمز للقلب.

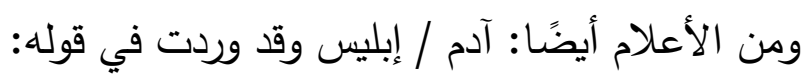

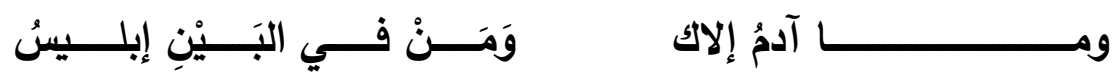
وواضح أنه وظفها هنـا على سبيل الرمز أيضًا؛ حيث رمز للذات العليا

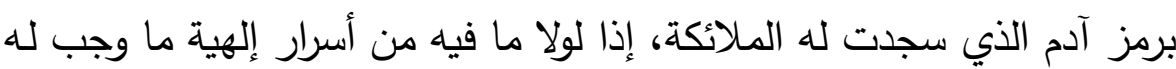

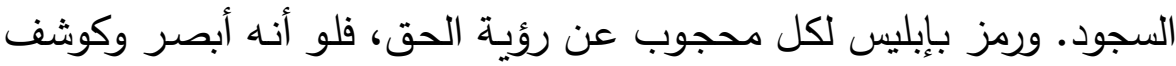
بحقيقة آدم ما تردد لحظة السجود. ذلك لأنه في البين محجوب. والملاحظ أن الحلاج لم يوظف أسماء النساء على سبيل الرمز كما فعل المتأخرون من شعراء الصوفية كابن الفارض وابن عربي وغيرهم، الذين ذكروا في شعرهم ليلى ولبنى وسعدى وغيرهـا، كما أنه لم يوظف أسماء الأماكن

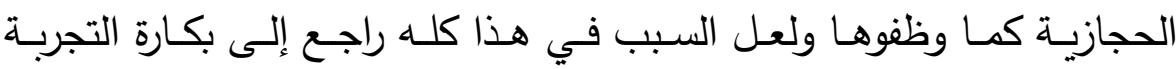
الصوفية في الثعر العربي كما أشرنا سابقًا.

\section{المستوى التركيي:}

جاءت تراكيب الحلاج متتوعة حسب الموضوعات والمعاني التي نتناولها، فإذا سلك في خطابه الشعري المسلك النظري أو بعبارة أخرى إذا غلب عليه

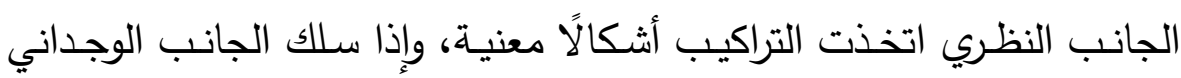

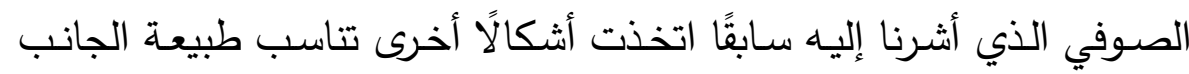


الذي يعبر عنـه. ومن هنـا نستطيع أن نؤكد على أثر المعاني والأفكار في صياغة التركيب الثعري.

ويمكن أن نجمل الخصائص التركيبة لشعر الحلاج على حسب مـا أشرنا إليه فيما يأتي:

- سلوك طريقة الخطاب الإرشادي وهي نتيجة طبيعية لحرصسه على شرح رؤيته النظرية من خلال شعره. وقد جاء ذلك من خلال جمل فعلية طلبية أو استفهامية مدعومة بالنداء، غرضها الطلب أو الحث على فعل شيء أو تركه، كما في مقطعته التي يقول فيها:

عصسيتَ وأنستَّ لـم تطلبْ رضـاه

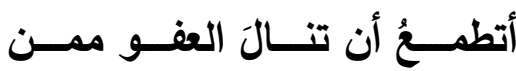

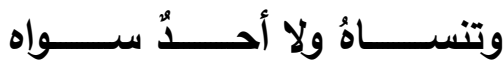

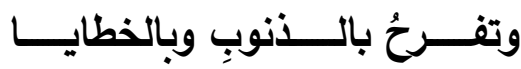
يُلاقِي العبــُ مـا كسبَتْ يسـاه

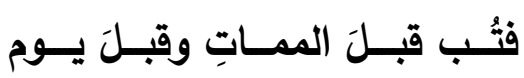
فهو يطلب من المتلقي -عن طريق أسلوب الاستفهام- أن يقلع عن الخطايا ويطلب الرضـا من خالفـه، وألا يفرح بالذنوب، وألا ينسى الله. ثم يطلب مـن خـلال فعـل الأمـر المباشـر أن يتوب قبـل المــات "فتب قبـل الممـات". وهــا الجانب الأخير "الطلب المباشر بفعل الأمر" يبرز من خلال مقطوعته التي يقول فيها:

ونــــادى الإيـــاس بقطــــع الرجــــا

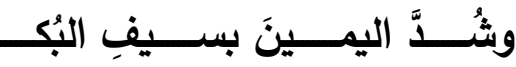

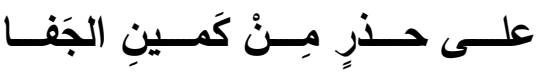
فَسِــز فــي مَثــاعلِ نــورِ الصَّــفا

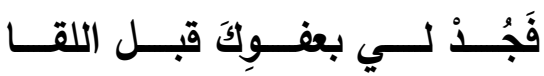

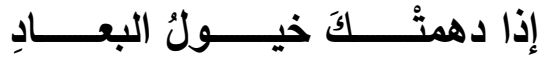

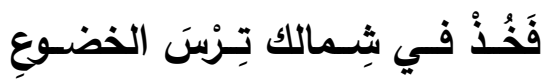

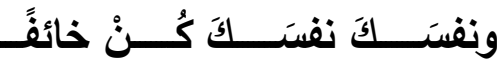

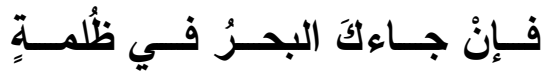

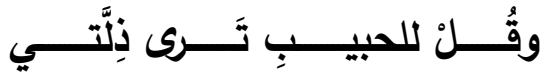




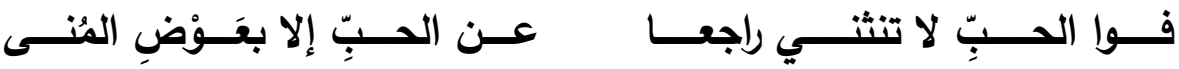
فنجده فيها يطلب من المتلقي من خلال فعل الأمر المباشر أمورًا عديدة: فخذ - وشُدَّ اليمين - كن خائفًا - فسر في مشاعل - وقل للحبيب. فكأنه يعمهـ ويلقنه ما يقول. -تميُّز بعض التراكيب بالتقسيم والترتيب. وهذا يلحق بالخصيصـة السـبقة ليدعم جانب شرح الرؤيـة النظريـة. فالحلاج في خطابه الثعري يأخذ أحيانًا سمت العالم الثـارح ليفصل للمتلقي نظريته كما أشرنا سـابقا، فتأتي التراكيب مناسبة لهذا التفصيل والتقسيم كما في قوله: والبحرُ بحرانِ: مركوبٌ ومرهوبُ والعلمُ علمانِ: مطبوعُ ومكتسبُ وإلناسُ اثنان: ممنوحٌ ومسلوبُ هُبُ

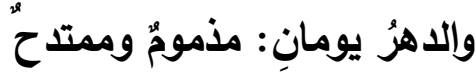
فيبدو هنا وكأنه عـالم شـارح يستخدم علامـات الترقيم التوضيحية ليفصل الكلام ويبيّنٍ القول، ثم يردف ذلك ببيت فيه فعلا أمرٍ طلبيان:

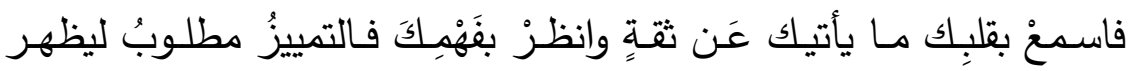
بوضوح هذا السمت التعليمي في الخطاب الشعري لديا. -كثرة استعماله أسلوب النداء: ولعل السبب في هذا يرجع إلى أن أسلوب النداء يصلح تمامـا في الجـانبين السـابقين، أعنـي الجانب النظري التعليمي، والجانب الوجداني الصوفي. فهو في الجانب الأول ينادي المتلقي كي يلقـه النظرية أو الفكرة أو النصح والإرشاد: يا غافلًا - يا من بات يخلو بالمعاصي -... إلى آخره. وفي الجانب الثاني يناجي ربّه وحبيبه ومعشوقه متلذذًا بالنداء ومرددًا إياه في مختلف حالاته الصوفية: يا موضـع الناظر من نـاظري - يا 
جملة الكل - يا سري ونجوائي - يا شمس يا بدرُ يا نهارُ - يا معين الضنى على - يا غاية السؤل والمأمول - يا من به علقت روحي ... إلى آخره. الإلغــاز في بعـض التراكيـب والمقطعـات: وقـــ تتاولنـا هـــه النقطــة بالتوضيح عند الحديث عن قصائده ومقطعاته الملغزة. •الحوار الثعري: من الخصـائص التركيبية في شعر الحـلاج اصطناع

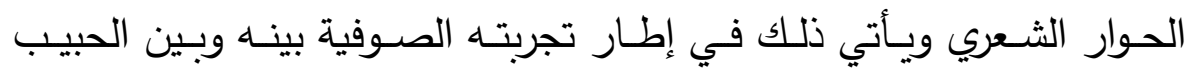
الأعلى، وخير شاهد على ذلك تلك المحاورة التي وردت في مقطعة من مخلع البسيط:

فققلتُ : مَنْ أنتَّ قَال: أنتَ أَيتُ ربّي بعيْنِ قَلْبِي وقد يأتي الحوار مع الأصحاب أو غيرهم:

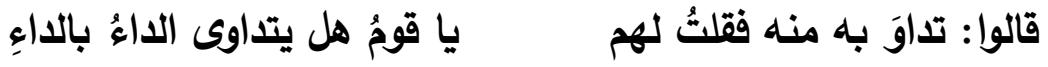
ولا يخفى ما للحوار الشعري من دور في حيوية الخطاب الشعري.

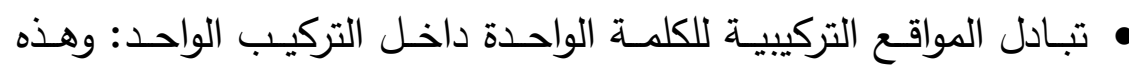
الخصيصة تتاسب حالة التوحد الصوفي أو الفناء التي يغيب فيها الثـاعر عن نفسـه، ويشعر بأنها في حالة جمع مـع محبوبـه، فيصبح المبتدأ والخبر شييًًا واحدًا كمـا في قولـه: روحسه روحي وروحي روحـه، وقولـه أيضًا: ذكره ذكري وذكري ذكره. وكذلك قوله:
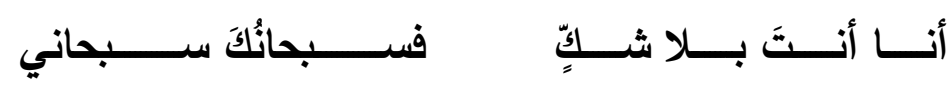

ويضـاف إلى ذلك إسناد الفعل الواحد لضمير المخاطب والمتكلم ليعبر عن فكرة التوحد بينهما كقوله: فإذا مسك شيء مسّني. كما يلحق بذلك أيضـا بعض 
الانحرافات الأسلوبية التي نتجت عن هذا التوحد الذي جمع بين المتناقضـات وجعل الحرف المتصل بضمير المتكلم "إني" أو "أني" يقوم مقام الضمير "أنا" أو مقام كلمة لها مدلولها الخاص عند الحلاج. يقول موظفًا كلمة "إنيّ":

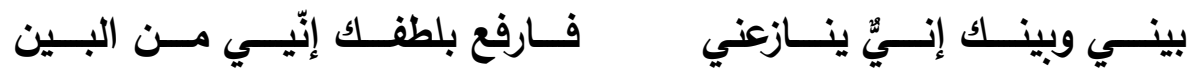
وهي كلمة "حلاجية" ابتدعتها تجربته الصوفية. ويلحق بما سبق استعماله بعض التعبيرات القريبة من أسلوب العامـة، وهذه التراكيب تعد أثرًا من آثار تواصل شعره مع عامة الناس. يقول من مقطعة له:

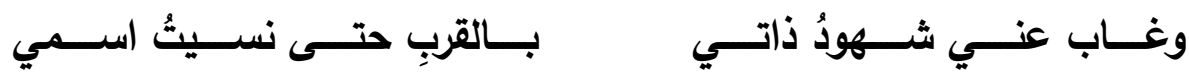
فجملة "حتى نسيت اسمي" ممـا يتداوله النـاس منذ زمن بعيد وحتى عصـرنا الحاضر والثيء نفسه نجده في قوله:

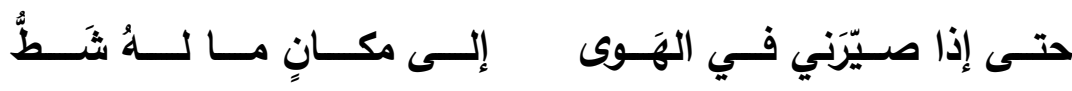

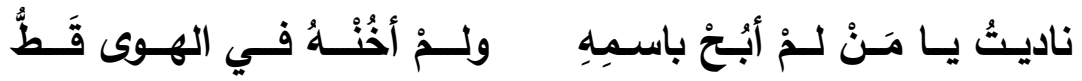

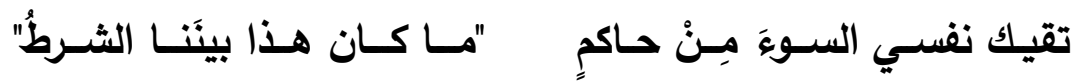
فجملة "مالـه شط"، وجملة "مـا كان هذا بينتا الشرط" من الجمل التي يتداولها عامة الناس أيضًا. التصوير (لفني: للتصوير الفني دور ملحوظ في شعر الحلاج، ويشمل عنده وصف حالات العشتق والفنـاء والتوحد، وكذلك يشمل أشياء أخرى كتصـوير الدنيا وغرورهـا، ومصاعب الطريق إلى الله، وسطوة القدر وعجز الإنسان. وطريقة الأداء التصويري عنده تتنوع ما بين صور جزئية وكلية، منها ما هو تقليدي مطروق، ومنها ما هو مبتكر • ومن صوره المبتكرة التي لم يُسبق 
إليها صورته التي عبر فيها عن سطوة الأقدار وعجز الإنسـان عن مواجهة مصيره بغير ما سطر له القدر وذلك في قوله:

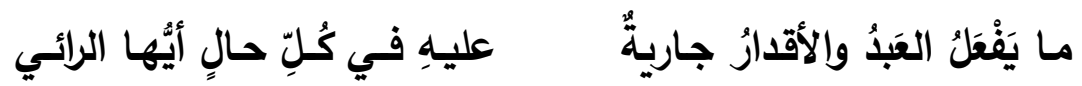

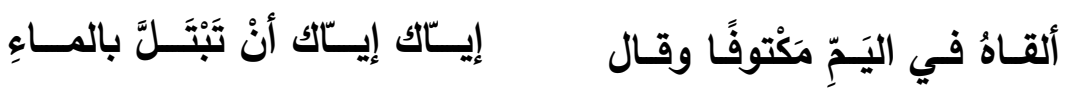
فبكارة هذه الصـورة ودقتهـا جعلتها مـثلا يتداولـه النـاس منـذ صـدرت مـن الحـلاج حتى عصـرنا الحاضـر، وهو في هذه الصـورة يصـور الإنسـان مقيدا بقيود العجز البشري الذي خُلق به وهو يُلقى في بحر الحياة المتلاطم، في خضم هذه الطبيعة القاسية، والأحكام الإلهية القهرية، من ميلاد وحياة ومرض

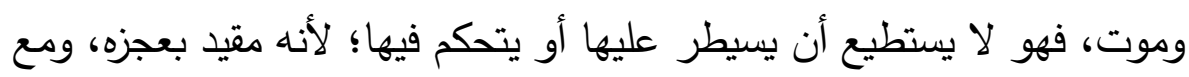

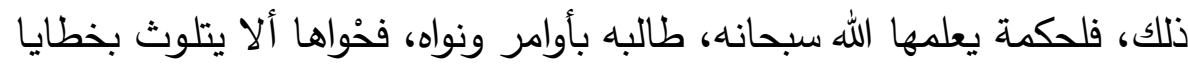
هذه الحياة التي لابد منها. وقد يبدو مدلول هذه الصورة أن فيها تمرد على القضـاء والقدر كما أثرنا سابقًا، ولكن النظرة المتأنية قد تكتشف فيها دلالات أخرى وبخاصـة من خلال معرفة القارئ بفكر الحلاج ودلالات شعره عامـة. فالحلاج صوفي عرف عنـه ونقل عنه ضرورة التسليم لأحكام القدر، وهو في هذه الصورة يريد أن يوضح مقدار الضـفف البشـري والعجز الإنساني الذي يجب أن يدفع الإنسـان إلى التمسك بخالقه القوي حتى يقوى على مواجهة كل الصعاب بل حتى يصل إلى درجة الفناء فيه، عندئذ لن يشعر أصـلً بسطوة هذه الأقدار، بل سيصل إلى حكمتها التي تغيب على سـائر البشر، وذلك هو الوصـول إلى الله، أو إلى درجة المعرفة. 
وقد صور الحلاج الدنيا الخادعة بصورة مطولة في مقطعة سبقت الإشارة

إليها وهي تلك التي يقول فيها:

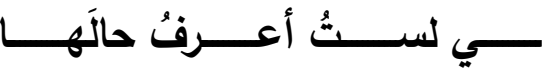

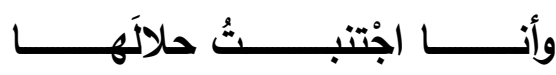

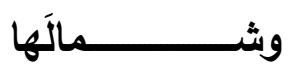

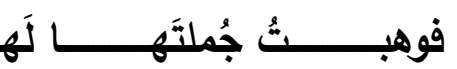

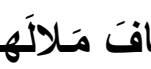

فرددتُه

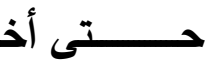

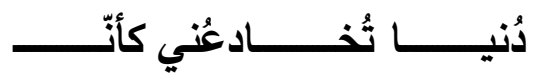
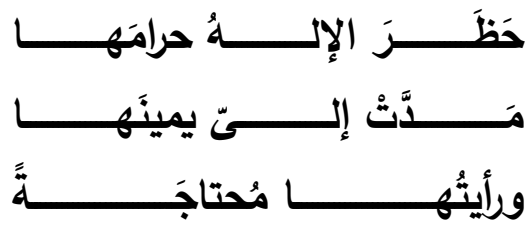

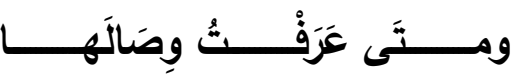

فهو يصور الدنيا بصورة حركية شاخصة حيث تحاول أن تغريه وتنال منه بوسـائل عديدة وهو ينـأى عنها "دنيا تخـادعني" مدت إليّ يمينها - فرددتها وشمالها.

وفي مقطعة أخرى نراه يصف ما لقيه في سبيل الهوى مصورًا نفسه "سندباد الهوى" كم هو مثبت في عنوان المقطعة بالديوان 51:

مازلـتُ أطفو فـي بِحسارِ الهـوى

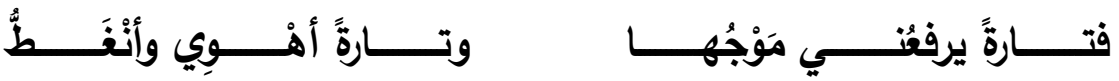

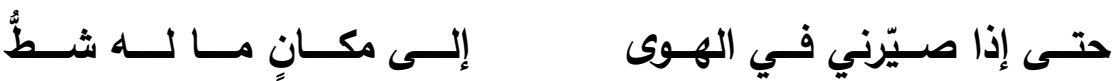

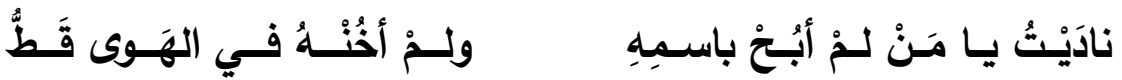

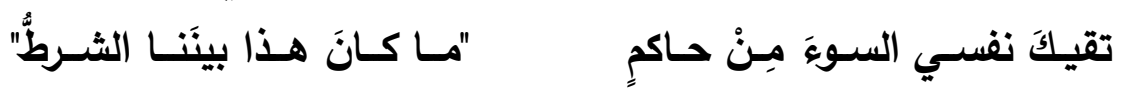
وفي هذه الصورة يبين لنا ما لاقاه في طريق الهوى من رفع وخفض وعلو وسقوط ثم يبين مدى الحيرة التي لم يصل معها إلى استقرار "إلى مكان ما لـه شط" ولعل هذه الحيرة هي أقصى ما يمكن أن يصل إليه العقل البشري. إذا لم يسلك سبيل القلب أو الروح الذي يفضى بدوره إلى التوحد ثم المعرفة.

(شعر الحلاج بين الؤية الصوفية والحطاب الشعري.) أ.د/ أنس الفقي 
ويأتي الحلاج بصور حسية ليعبر من خلالها على حالة التوحد أو التواصل بينه وبين محبوبه الأعظم يقول:

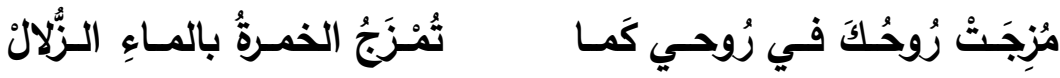

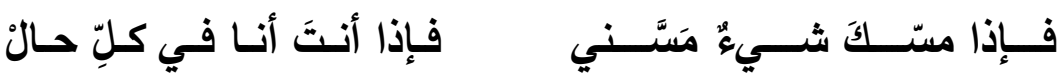
فقد صور هنا حالة الامتزاج الروحي مع حبيبه بمزج الخمرة بالماء الزلال، واختياره هذه الصورة نابع من ظلالها الغزلية، كما أن لها جانب مقدس "خمرة الآخرة". ويكرر الحلاج هذه الصورة "صورة الامتزاج" في موضع آخر بمفردات أخرى:

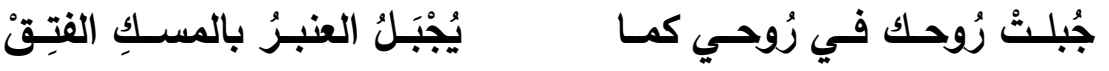

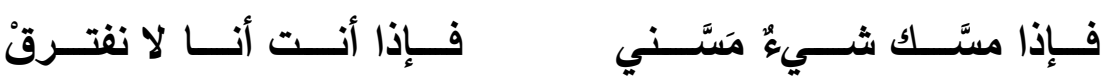
فجاء هذه المرة بصورة العنبر والمسك يعبر من خلالهما على امتزاج روحهـ بروح محبوبه. والعنبر والمسك منم الروائح الطيبة التي تضفي جوًّا من العبق المقدس على دلالة الصورة. وجاءت بعض الصورة عند الحلاج مباشرة ومتداولتة كقولهـه مخاطبا حبيبه

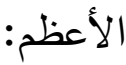

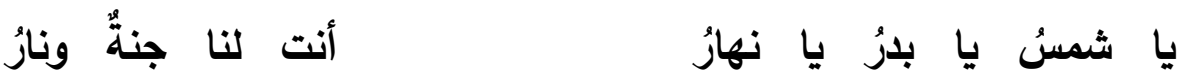
وحينما يصور الحلاج جمال محبوبه فإنه يلجأ إلى الصور التي تفيد الحسن المعنوي المقدس، وندر أن يصفه وصفًا يفيد الحسن الحسي كجمال العين والطرف الخد والقد، لذلك لم نجد غير موضع واحد وصف فيه هذا الجانب

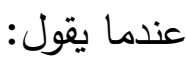




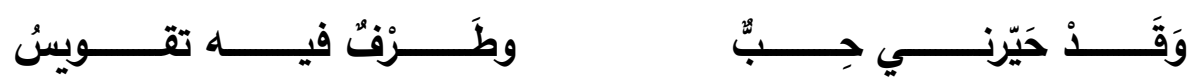

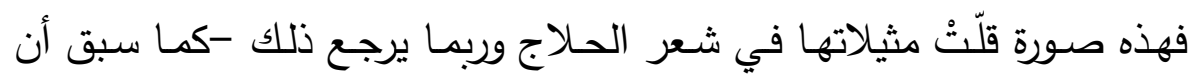

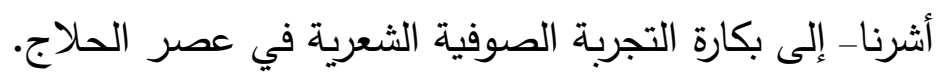
ومن الصور المعبرة عن مكانة المحبوب الأعظم في نفس الثاعر قوله:

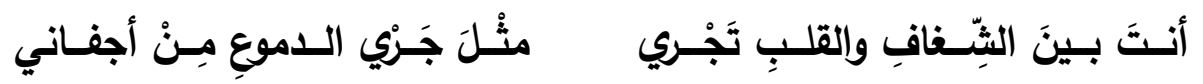

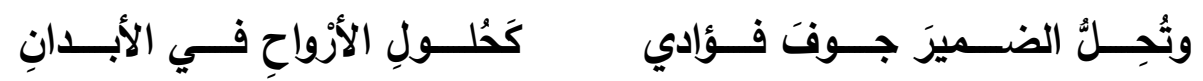

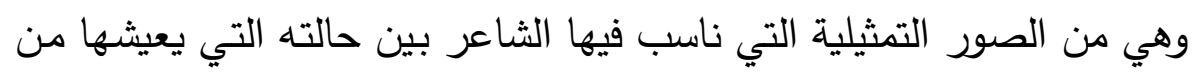

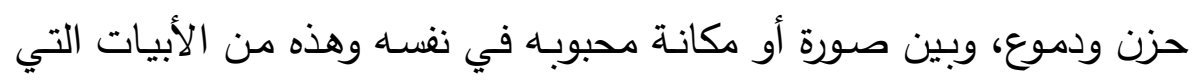
تناقلها أصحاب التراجم والمؤرخون عن الحلاج وأبدو إعجابهم بهاندأ. 


\section{خاتمة البحث}

بعد هذه التطوافة في شعر الحلاج، نستطيع أن نخلص إلى مجموعة من النتائج التي يمكن أن تسهم بالمزيد في التعرف على هذه الشخصية الصوفية وهذا النتاج الثعري الرائد في مجال التصوف. وهذه النتائج تتلخص في النقاط التالية: - شعر الحـلاج في التصـوف يمثل بكارة التجربـة الثـعرية الصـوفية في التراث العربي، فهو لـم يصل -في مجمله- إلى مرحلة النضـج الفني، هذا بالإضـافة إلى أن بعض مقطعاته جاءت ضمن مواقف ارتجالية على نحو ما ورد بأخباره، ولذلك لا نجد فيه مزيدًا من التوظيف الفني للرمز الصوفي، مثلما فعل ابن الفارض وابن عربي وغيرهما من كبار شعراء الصوفية الذين جاءوا بعده. ولعل عدم التوفيق في توظيف الرمز الصوفي كان السبب الرئيسي وراء تلك الثطحات المباشرة التي صدمت رجال الثريعة. - يغلب على شـعر الحـلاج الجانـب النظري الفكري، وقد أثر ذلك في أسلوب الخطاب الثـعري؛ فبـدا الثـاعر في كثير من مقطعاته وكأنه شـارحُ نظرية أو موضح فكرة. ـ تُعدُّ الرؤيسة النظريـة عند الحلاج المنطلق الأساسي لشعره بصفة عامـة، وتتمثل في نظرته العليا للإنسان الذي يحمل بداخله سرّ العبودية والألوهية، فهو -في نظر الثاعر - يملك إرادة لا حدود لها يمكن أن توصله إلى الحقيقة المطلقة، كما تتمثل في نظرته غير التقليديـة إلى الثـريعة؛ حيث جمـع بين احترامه لها وتوسُّعه في فهم حقائقها، وقد عبر في شعره عن هذا التوشُّع بما لا

$$
\text { (شعر الحلاج بين الؤية الصوفية والحطاب الشعري.) أ.د/ أنس الفقي }
$$


تطيقـه أفهام عامـة النـاس وبعض رجـال الشـريعة، فكانـت الشـطحات، وكـان

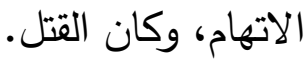

- على الرغم من طغيـان الجانب النظري في شعره عامـة إلا أن للحلاج بعض القصـائد والمقطعـات التي عبر فيهـا عن تجربتهـ الصـوفية الخالصـة، وبخاصة تلك التي تتعلق بالعشق الإلهي وما يصاحبه من معان وجدانية. - نال الجانب الموسيقي حظًّ وافرًا في شعر الحلاج، فقد جاءت جلٌّ قوافيه من النوع المتواتر المردف، الذي يناسب الغناء والإنشاد، وبالتالي يساعد على انتشار شعره بين الناس. - ظاهرة التكرار في شعر الحـلاج من الظواهر اللافتة، وقد وضّح البحث أن التجربـة الصـوفية بشقيها: النظري والوجداني كانـت سببًا مباشرًا في هذه الظاهرة.

- إيثار الحـلاج للمقطعـات الصـغيرة والثنائيات في شعره يدفع إلى القول بتأثره بنمط من الثعر الفارسي، وهو ما يُسمى "بالدوبيت" أو المثنوي، وإن لم ينظم على وزنه، بل إنه نظم هذه الثنائيات على الأوزان العربية المعهودة، ومع هذا، فإن ذلك يُعدُّ بداية تأثر ظاهري بالثكل العام. ومن الجدير بالذكر أن هذا التأثر قد تطور في العصور اللاحقة؛ حيث كتب الثعراء هذه الثنائيات باللغة العربية وبالوزن الفارسي. - حرص الحـلاج في شعره على الاقتراب من أذواق العامـة، ومن مظاهر ذلك: استعماله بعض العبارات المتداولة، والمصطلحات اللافتة، وأحيانًا اللغز المصطنع بتوظيف حروف الهجاء. 
- للتصوير الفني عند الحلاج دور ملحوظ في أداء الرسالة الشعرية، وعلى الرغم مما أشرنا إليه سـابقًا من عدم بلوغ شعره الصوفي عامـة مرحلة النضـج الفني، إلا أن أداءه التصويري قد يبلغ أحيانًا مستوى راقيًا بحيث يصل إلى حد الاستشهاد البلاغي بصوره المتقنة التي تجري مجرى المثل أو الحكمة كقوله المشهور :

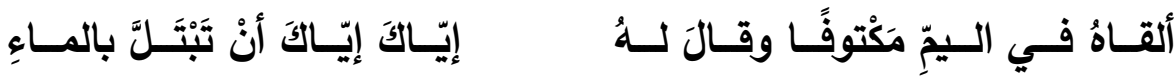
وأخيرًا فإن قِلّة ما وصلنا من شعر الحلاج، والتضـارب القائم حول الشعر الذي نسب إليه وإلى غيره في كتب التراجم، يدفع الباحث إلى التوصية بتكثيف البحث وإعـادة النظر في هذا الثـعر (المنسـوب إليـه وإلى غيره)، ومحاولـة التحقق منه، لتكتمل الصورة، وتتحقق الفائدة. 


\section{الحواشي}

* الحسين بن منصور الحلاج أبو عبدالله، ويقال: أبو مغيث، من أهل بيضاء فارس، نثأ بواسط والعراق، وصحب سهل بن عبدالله التستري، وصحب الجنيد وغيره ببغداد، وكان كثير الترحال والأسفار والمجاهدة، ومن الغارقين في حقائق التصوف، وله وله شطحات مشهورة

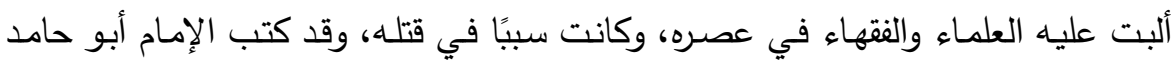

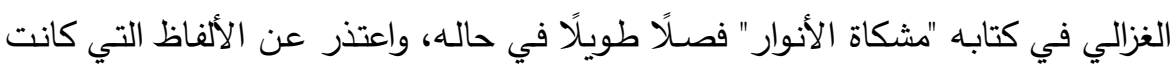

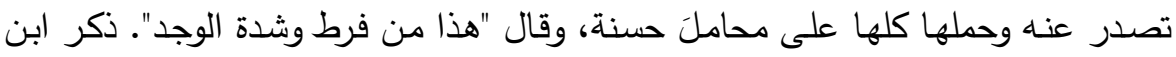
خلكان أنه قُتل سنة تسع وثلاثمائة (309هـ). 1 33 لقعمان 12

2) الكلاباذي - التعرف لمذهب أهل التصوف - دار الكتب العلمية - بيروت - الطبعة

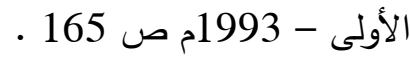
3) السابق - ص الأى 167

4) "وقال الحسين بن منصسور : إن القدم له، فالذي بالجسم ظهوره فالعرض يلزمها، والذي

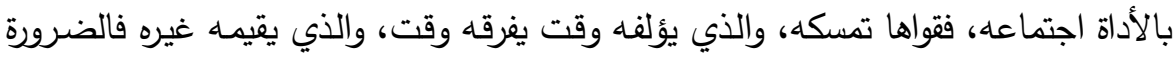
تمسه، والذي يظفر به الخيال فالتصور يرتقي إليه، ومن آواه محل أدركه أين، سبحانه لا لا لأل

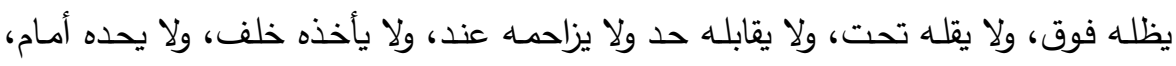

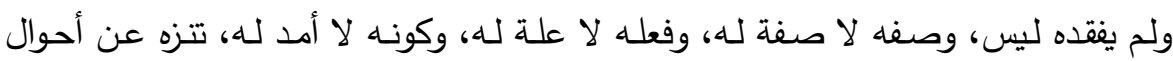

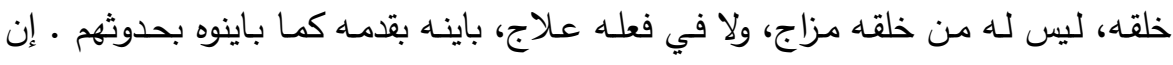

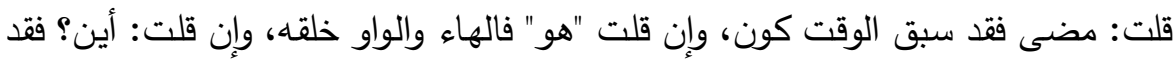

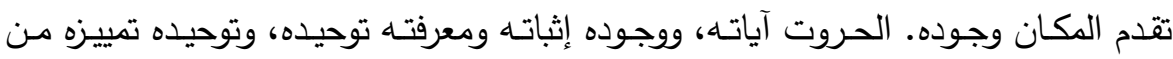

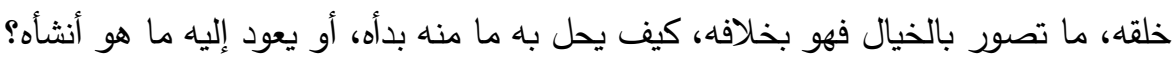

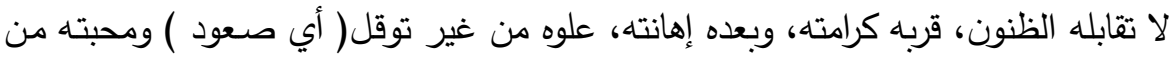

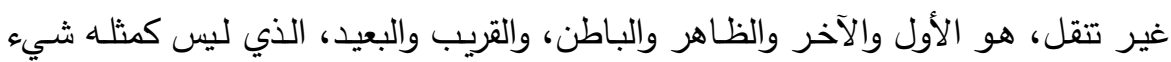

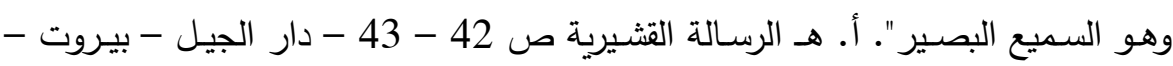
الطبعة الثانية.

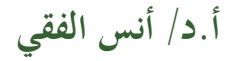

(شعر الحلاج بين الؤية الصوفية والحطاب الشعري.) 
5

6- ديوان الحلاج وأخباره وطواسينه - جمع د. د. سعد ضناوي - دار صـادر - بيروت الطبعة الأولى - 1998 - ص 148 7 - السابق -ص الاكم 120.

8 - كذا في الديوان وقد تكون " نما "

94 - الإسراء 44

10 - الرعد الإنراء 15

11 - د.شوقي ضيف - تاريخ الأدب العربي - العصر العباسي الثاني - دار المعارف -

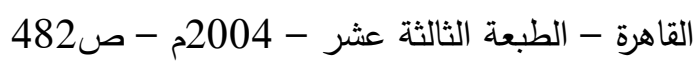

12 - جاء في كتاب التعرف في باب القدر" أجمعوا أن الله تعالى خالق لأفعال العباد

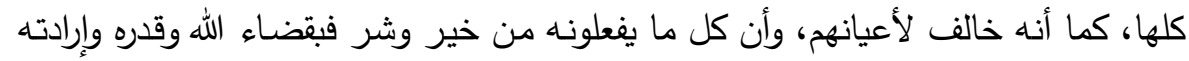

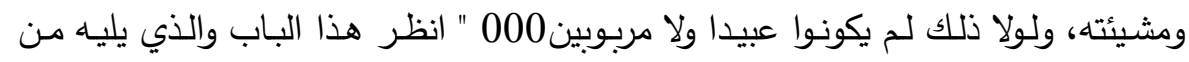
كتاب التعرف لمذهب أهل التصوف الكلاباذي ص ولك 23 وما بعدها.

13- الحديد 4

14 - سورة ق 16

15 -الزخرف 84

16 - يقول ابن عطاء الله السكندري في حكمه: كيف يتصور أن يحبه شيء وهو الظاهر فوق كل شيء كيف يتصور أن يحجبه شيء وهو الذي أظهر كل شيء ابن عطاء الله السكندري بشرح الثيخ أحمد زروق - تحقيق دكتور عبد الحليم محمود كتاب الثعب - 1985 صناء ع44 - 1985. 17 - ديوان الحلاج وأخباره وطواسينه - ص - 18 18 - السابق ص 147 19 - الكلاباذي - التعرف لمذهب أهل التصوف - ص 70 - 71 - 71 20 - حذفت همزة أزمان لتناسب الوزن.

21 - ابن عطاء الله السكندري - لطائف المنن - تحقيق د عبد الحليم محمود - ط كتاب

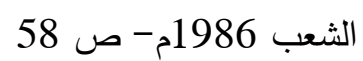

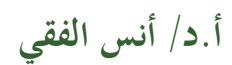

(شعر الحلاج بين الؤية الصوفية والحطاب الشعري.) 
22 - غربيب: المقصود هنا مظلم حالك السواد، ورد في القاموس: أسود غربيب: حالك. القاموس: غرب 23 - الأعراف 172

24 - السلمي- طبقات الصـوفية - الخـانجي - القـاهرة - الطبعـة الثالثة - 1986 ص 307 25 - انظر الموقف في أخبار الحلاج- ص ص 117، بداية الحلاج ونهايته لابن باكويه. ص184 - ممع د سعد ضناوي. 26 - انظر ترجمته بطبقات السلمي صد د د 265 27 - من القضاة الذين شهدوا ببراءة الحلاج من الكفر أبو العباس بن سريح حيث ورد في أخبار الحلاج : عن إبراهيم بن شيبان قال: دخلت على ابن سريح يوم قتل الحلاج فقلت:

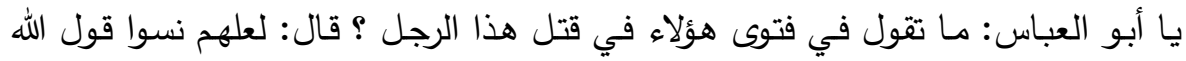

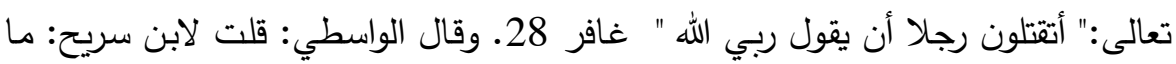

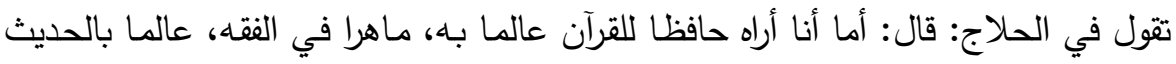

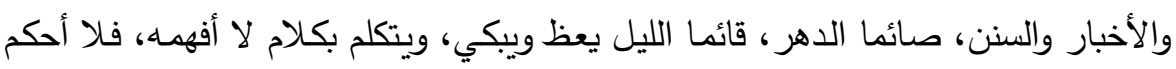

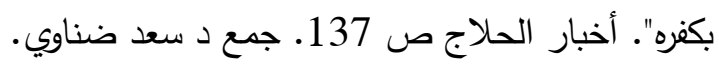

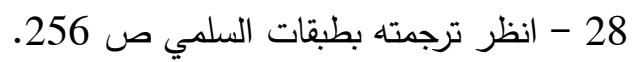
29 -ديوان الحلاج وأخبار وطواسينه - ص 28141 30

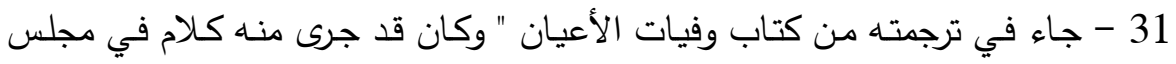
حامد المقتدر بحضرة القاضـي أبي عمر وقد قرئ عليه رقعة بخطه أن الإنسان إذا أراد

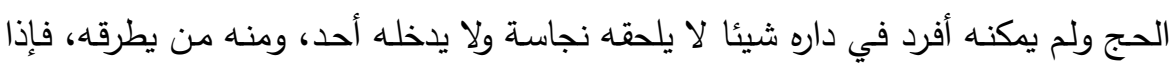

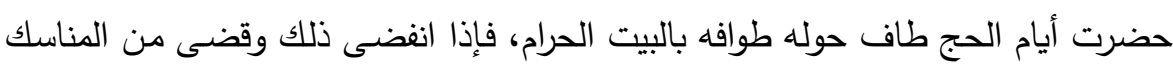

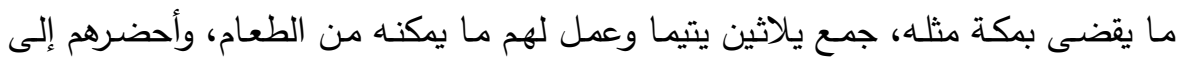

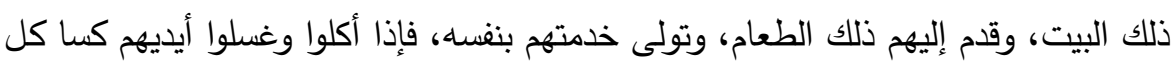

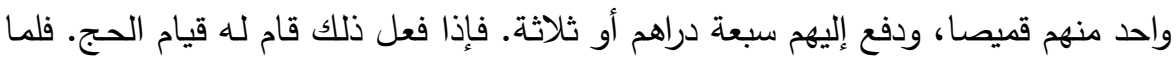

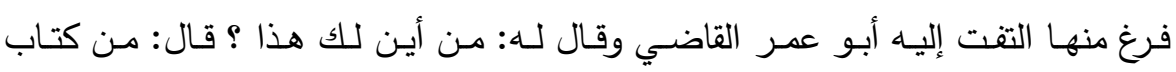

(شعر الحلاج بين الؤية الصوفية والحطاب الشعري.) أ.د/ أنس الفقي 
"الإخلاص " للحسن البصري، فقال له أبو عمر ك كذبت يا حلاج، اللهم قد سمعنا كتاب "

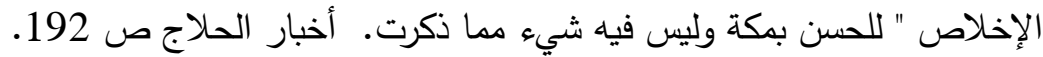

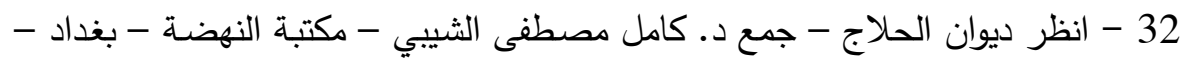

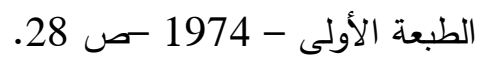
33 - انظر ما سينون - أخبار الحلاج - المكتبة الفلسفية - باريس - 1957 -ص 25 - 25 $.26-$ 34 - ديوان الحلاج وأخباره وطواسينه - ص 128 - 125

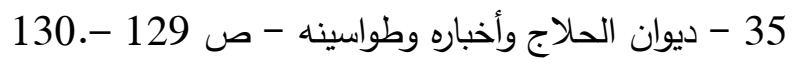

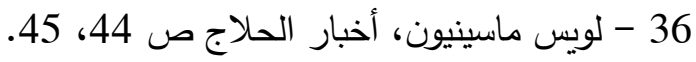

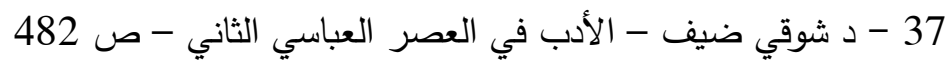
38 - ديوان الحلاج وأخباره وطواسينه - ص د 39

39 - علم الحروف والدوائر من العلوم القديمة التي اهتم بها كثير من الصوفية وغيرهم.

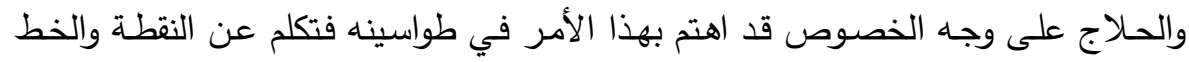

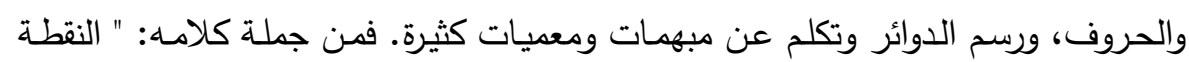

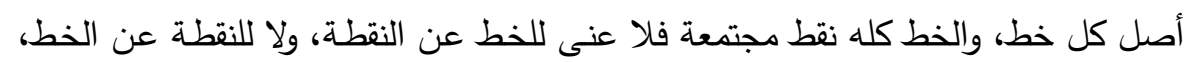

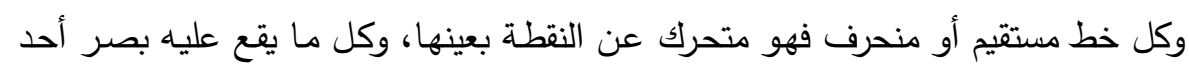

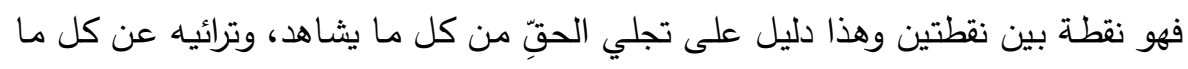

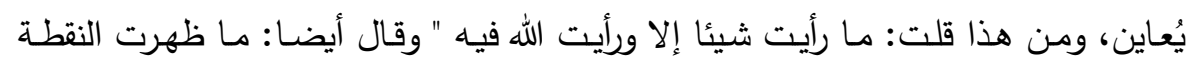

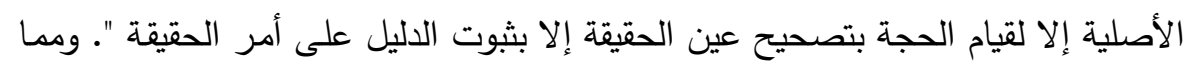

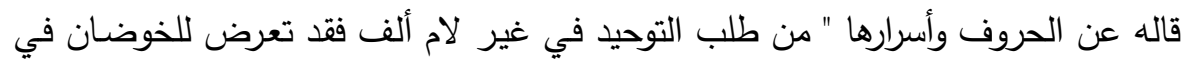

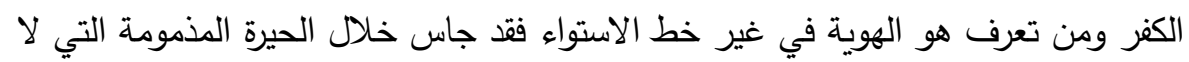

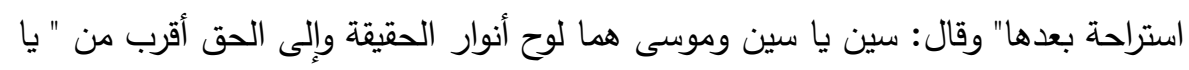

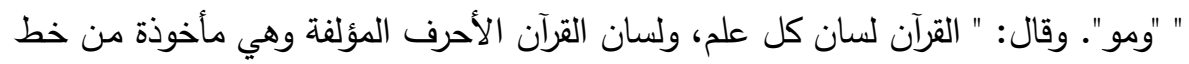

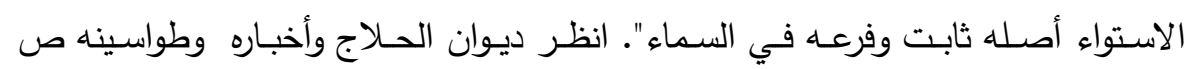

$$
\text { .121- } 120-109
$$

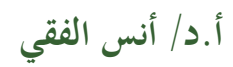

(شعر الحلاج بين الؤية الصوفية والحطاب الشعري.) 
40 - وهذه المقطوعة أيضا وردت في سياق خبر من أخبار الحلاج، حيث يروى أن رجلا

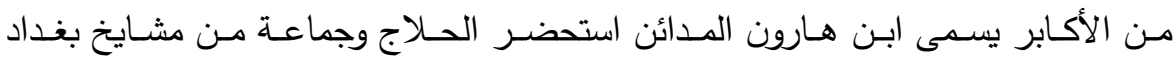

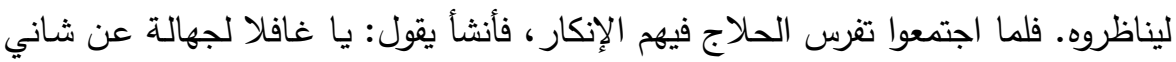
0000 فبهت القوم. السابق ص 124. 41

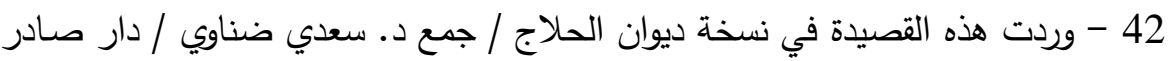
ص 65، ولم ترد بنسخة الديوان الذي جمعه د. الثيبي.

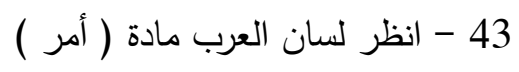

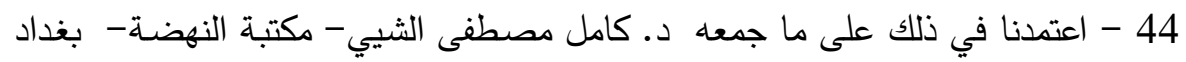
- الطبعة الأولى - 1974 - 1974 م.

45 - في الطبعة الأخرى من ديوان الحلاج توجد قصيدة نونية منسبة إليه تبلغ34 بيتا تبدأ

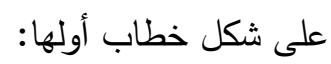

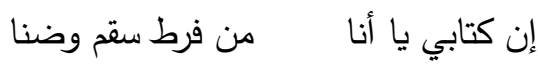

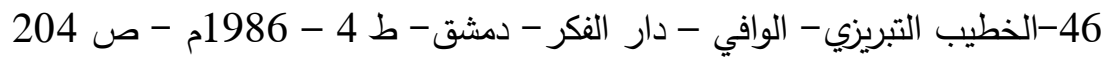

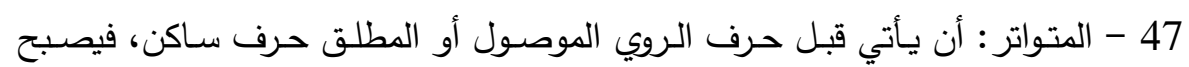

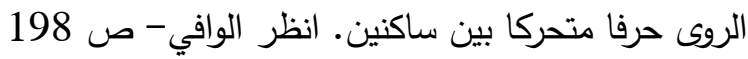
48 - راجـع باب السماع في مصـادر التراث الصـوفي مثل: التعرف / اللمـع / الرسـالة القشيرية. 49 - يوري لوتمان - تحليل النص الثعري- ترجمة وتقديم د. محمد فتوح أحمد - دار المعارف- القاهرة 1995 - ص979 لونمان 50 -انظر د.محمد مفتاح- تحليل الخطاب الثعري - دار التتوير - بيروت - لبنان -

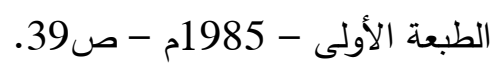
51 - انظر الديوان - جمع الدكتور كامل مصطفى الثيبي - ص 52 52 -انظر طبقات الصوفية- السلمي-- ص 309 


\section{مراجع البحث}

1. ابن باكويهـ - بداية الحلاج ونهايته (ملحق بالديوان)- جمع د سعد ضناوي- -

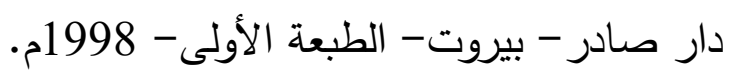

2. جون كوين - بناء لغة الثعر - ترجمة د أحمد درويش - الهيئة العامة لقصور الهور

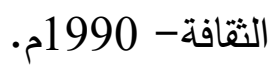

3. الحلاج- ديوانه- جمع د. كامل مصطفى الثيبي - مكتبة النهضـة - بغداد

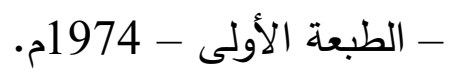

4. الحلاج - ديوانه وأخباره وطواسينه - جمع د. سعد ضناوي - دار صـادر -

$$
\text { بيروت - الطبعة الأولى - } 1998 .
$$

$$
\text { 5. الخطيب التبريزي- الوافي - دار الفكر - دمشق - ط } 4 \text { - 1986م. }
$$

6. ابن خلكان - وفيات الأعيان - تحقيق د إحسان عباس- دار صادر بيروت. 7. السـراج الطوسي - اللهع - تحقيق د عبد الحليم محمـود وطـه سـرور - دار

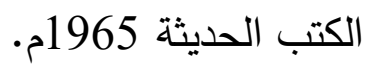

8. السلمي- طبقات الصوفية - الخانجي - القاهرة - الطبعة الثالثة - 1986

9. د شكري عياد - مـدخل إلى علم الأسلوب - أصـدقاء الكتاب -ـالقـاهرة-

1996

10. د.شوقي ضـيف - تاريخ الأدب العربي - العصـر العباسـي الثاني - دار

$$
\text { المعارف - القاهرة - الطبعة الثالثة عشر - 2004م. }
$$

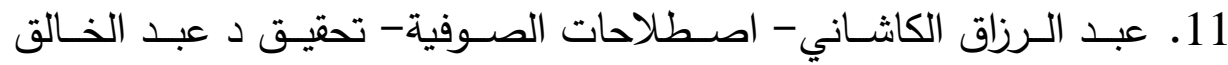
محمود- دار المعارف- القاهرة- الطبعة الثانية- 1984م. 
12. ابـن عطاء الله السكندري - الحكم - بشـرح الثـيخ أحمد زروق - تحقيق كئ دكتور عبد الحليم محمود - كتاب الثعب - 1985 م.

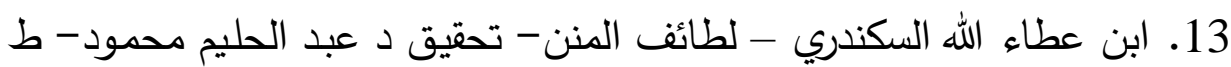

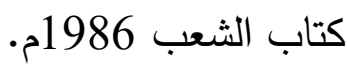

14. أبـو القاسـم القشـيري- الرسـالة القشـيرية- دار الجيـل - بيـروت - الطبعـة الثانية.

15. الكلاباذي - التعرف لمذهب أهل التصوف - دار الكتب العلمية - بيروت - الطبعة الأولى - 1993م.

16. د محمـد عبد المـعم خفـاجي- الأدب في التراث الصـوفي- دار غريـبالقاهرة-1980م.

17. د.محمد مفتاح- تحليل الخطاب الثعري - دار التنوير - بيروت - لبنان الطبعة الأولى - 1985م.

18. لويس ما سينون - أخبار الحلاج - المكتبة الفلسفية - باريس - 1957م.

19. يوري لوتمان - تحليل النص الثعري- ترجمة وتقديم د. محمد فتوح أحمد دار المعارف- القاهرة 1995. 


\section{Al-Hallaj's Poetry Between the Sufi Viewpoint and the Poetic Discourse Prof.Dr. Anas Attia Al-Feki}

\section{$\underline{\text { Abstract }}$}

This study aims at probing the depths of the Sufi viewpoint through tackling the poetic discourse in the poetry of Al-Hussein Bin Mansour Al-Hallaj; the great Sufi poet who represents the pioneer generation of Sufism; the Sufism of the third and fourth centuries AH, who was killed as a victim of his own beliefs and who sparked a heated debate in the east and the west.

Indeed, the nature of Al-Hallaj's poetry is the reason of choosing the title of the research because his poetry in general does not go beyond three aspects:

First aspect: Putting forth the theoretical viewpoint through an accompanying emotional experience

Second aspect: Putting forth the theoretical viewpoint directly where the poet's spirit totally or almost disappears

Third aspect: Describing his emotional state without deliberately proposing a specific viewpoint; this aspect incorporates the poetry of divine love together with the associated states.

Hence, the research is divided into three parts:

Part one tackles the theoretical viewpoint in AlHallaj's poetry which constitutes the larger portion of his

(شعر الحلاج بين الؤية الصوفية والحطاب الشعري.) أ.د/ أنس الفقي 
poetry and deals with the abovementioned first and second aspects. It is the poetry that encompasses Al-Hallaj's theoretical viewpoint and ideas that he wants to propagate and deliver to people. These ideas or viewpoint are no more than the Sufi conception of life and the universe whose most outstanding issues will be tackled in Al-Hallaj's poetry such as his attitude to Islamic Law ("sharia"), his view of man's soul and body, unity of religions, the inevitability of fate and the necessity of submitting to one's destiny, the mind's confusion, the issue of knowledge and science, and company on the path of mysticism. This part tackles two points related to this viewpoint namely; AlHallaj's deviations and puzzling poetical compositions.

Part Two deals with the third aspect; the Sufi emotional poetry that he composed as an expression of his Sufi state; love, yearning, unity, and communication, or of complaint, pain, and sadness. That is to say it is the poetry that reflects his pure Sufi experience without any intention to propose a viewpoint, clarify an idea, or propagandize a specific theoretical thought.

Part Three deals with the stylistic features of AlHallaj's poetry in general; the music, the poetic lexicon, the structures, and the art imagery. This helps in forming a comprehensive picture of this leading Sufi poetic production.

Finally, it is important to point out that Al-Hallaj's poetry is often mentioned in the context of prosaic texts that constitute an intellectual framework serving as a guide

$$
\text { (شعر الحلاج بين الؤية الصوفية والحطاب الشعري.) أ.د/ أنس الفقي }
$$


مجلة جامعة مصر للدراسات الإنسانية ( اللغويات والآداب ) مجلد 1 عدد 1 يناير (2021)

to our understanding of the poetry. That is why it is appropriate to use some of these prosaic texts in the discussion of the related stanzas.

The research results can be summed up in the following:

- Al-Hallaj's Sufi poetry represents the early Sufi poetic experience in the Arab heritage; that is to say it hasn't reached, in general, the state of artistic maturity. In addition, some of the stanzas appear in improvised situations like those mentioned in the prosaic texts. Hence, the artistic employment of the Sufi symbol is not excessively present in his poetry unlike the subsequent great Sufi poets like Ibn Al-Farid, Ibn Arabi, among others. Perhaps the unsuccessful employment of the Sufi symbol was the reason behind his deviations that shocked the sharia' scholars.

- Al-Hallaj's poetry is dominated by the intellectual theoretical aspect which affects the style of poetic discourse; so that in many of his stanzas, he seems to be explaining a theory or clarifying an idea.

- Al-Hallaj's theoretical viewpoint is the basic premise of his poetry in general and is represented through his superior view of man who encompasses within him the secret of servitude and divinity since he possesses, in the eyes of the poet, a boundless will that can lead him to absolute reality. Al-Hallaj's theoretical viewpoint is also represented through his untraditional perspective of Islamic law (sharia') which combines respect and an expanded

(شعر الحلاج بين الؤية الصوفية والحطاب الشعري.) أ.د/ أنس الفقي 
مجلة جامعة مصر للدراسات الإنسانية ( اللغويات والآداب ) مجلد 1 عدد 1 يناير (2021)

understanding of its reality. In his poetry, Al-Hallaj expressed this expanded understanding which was unacceptable to common people as well as to some sharia' scholars. Hence came the deviations, the accusation, and the murder.

- Despite the domination of the theoretical aspect in Al-Hallaj's poetry in general, in some of his poems and stanzas he expresses his pure Sufi experience, specifically that related to divine love and the associated emotional meanings.

- Music is carefully treated in Al-Hallaj's poetry so that most of the rhymes are rhythmic which is appropriate to singing and chanting. This helped in making his poetry popular among people.

- Repetition is an outstanding feature in Al-Hallaj's poetry. The research reveals that the Sufi experience; in both the theoretical and emotional aspects, is directly responsible for this feature.

- Al-Hallaj's preference of short stanzas and couplets leads us to say that he was influenced with a type of Persian poetry called the "Dubet" or two-line stanzas although he didn't use the same meter. He rather composed these couplets using the well-known Arabic metrical patterns. However, he was considered to be superficially influenced with the general framework. It is worth noting that this influence developed in subsequent ages where these couplets were composed by poets using the Arabic language and the Persian meter.

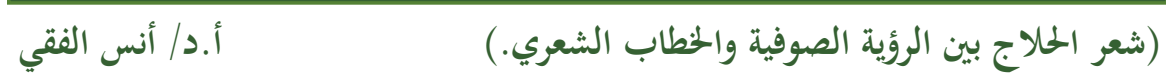


- In his poetry, Al-Hallaj is keen on addressing the tastes of common people which is evident in using some everyday phrases, catchy expressions, and sometimes the riddles made up by employing the alphabet.

- In Al-Hallaj's poetry, art imagery plays a remarkable role in rendering the poetic message. Although his Sufi poetry in general, as mentioned before, has not reached the state of artistic maturity, his manipulation of imagery is sometimes so refined that his images are used as perfect rhetoric citations that work as proverbs or wise sayings such as his famous saying:

He was thrown into the sea tied up and ordered

Never to get wet with water

- - Finally, the dearth of what we have received from Al-Hallaj's poetry, and the conflict that exists about the poetry attributed to him and others in the books of translations, prompts the researcher to recommend intensifying research and reviewing this poetry (attributed to him and others), and trying to verify it to view the picture in full and get the full benefit.

keywords: Al-Hallaj - Al-Hallaj's poetry - Al-Hallaj's deviations - Al-Hallaj's puzzling poetical compositions Sufi poetry. 